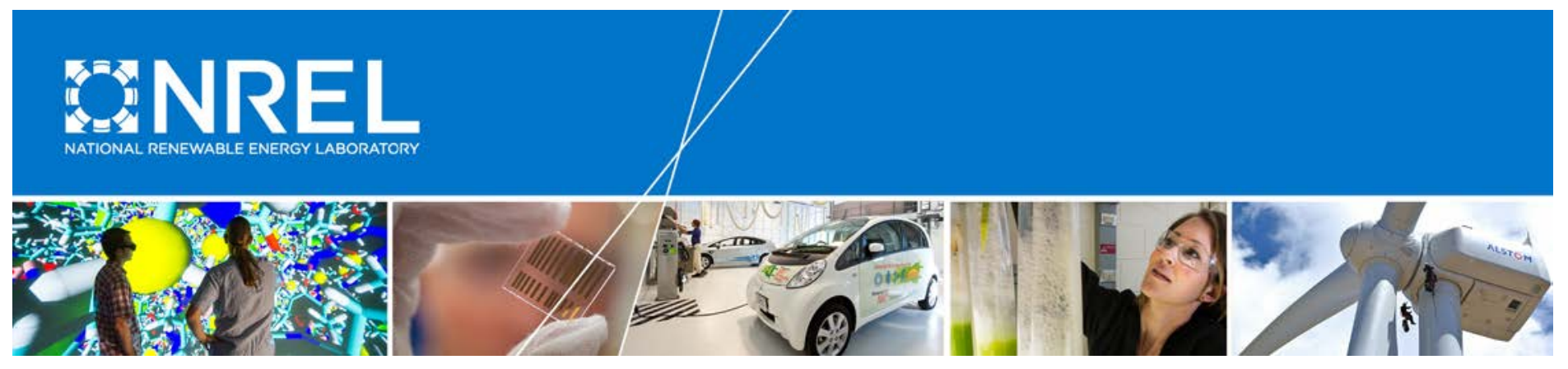

\title{
Wildlife and Vegetation Monitoring Report at the National Wind Technology Center
}

\author{
ERO Resources \\ Denver, Colorado
}

NREL Technical Monitor: Tom Ryon

NREL is a national laboratory of the U.S. Department of Energy Office of Energy Efficiency \& Renewable Energy Operated by the Alliance for Sustainable Energy, LLC

This report is available at no cost from the National Renewable Energy Laboratory (NREL) at www.nrel.gov/publications.

\section{Subcontract Report}

NREL/SR-1900-70362

June 2018 


\title{
Wildlife and Vegetation Monitoring Report at the National Wind Technology Center
}

\author{
ERO Resources \\ Denver, Colorado
}

NREL Technical Monitor: Tom Ryon

\section{Suggested Citation}

ERO Resources. 2018. Wildlife and Vegetation Monitoring Report at the National Wind Technology Center. 2018. Golden, CO: National Renewable Energy Laboratory. NREL/SR-1900-70362

https://www.nrel.gov/docs/fy18osti/70362.pdf.

NREL is a national laboratory of the U.S. Department of Energy Office of Energy Efficiency \& Renewable Energy Operated by the Alliance for Sustainable Energy, LLC

This report is available at no cost from the National Renewable Energy Laboratory (NREL) at www.nrel.gov/publications.

National Renewable Energy Laboratory 15013 Denver West Parkway Golden, CO 80401

303-275-3000 • www.nrel.gov

\section{Subcontract Report}

NREL/SR-1900-70362

June 2018

Contract No. DE-AC36-08GO28308 
This publication was reproduced from the best available copy submitted by the subcontractor and received no editorial review at NREL.

\section{NOTICE}

This work was authored by the National Renewable Energy Laboratory, operated by Alliance for Sustainable Energy, LLC, for the U.S. Department of Energy (DOE) under Contract No. DE-AC36-08GO28308. Funding provided by the U.S. Department of Energy Office of Energy Efficiency and Renewable Energy. The views expressed in the article do not necessarily represent the views of the DOE or the U.S. Government.

This report is available at no cost from the National Renewable Energy Laboratory (NREL) at www.nrel.gov/publications.

U.S. Department of Energy (DOE) reports produced after 1991 and a growing number of pre-1991 documents are available free via www.OSTI.gov.

Cover Photos by Dennis Schroeder: (left to right) NREL 26173, NREL 18302, NREL 19758, NREL 29642, NREL 19795.

NREL prints on paper that contains recycled content. 


\section{ERO}

Consultants in Natural Resources and the Environment

\section{Wildlife and Vegetation Monitoring Report National Wind Technology Center Jefferson County, Colorado}

Prepared for-

National Renewable Energy Lab

15013 Denver West Parkway

Golden, Colorado 80401

Prepared by-

ERO Resources Corporation

1842 Clarkson Street

Denver, Colorado 80218

(303) 830-1188

October 19, 2016 


\section{Contents}

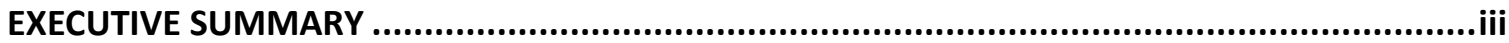

INTRODUCTION

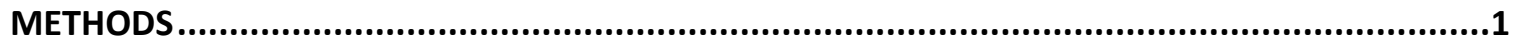

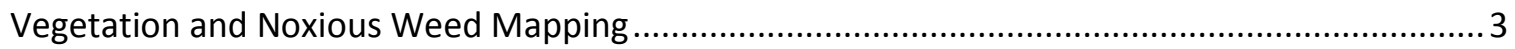

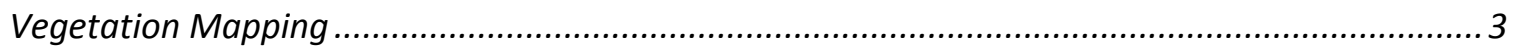

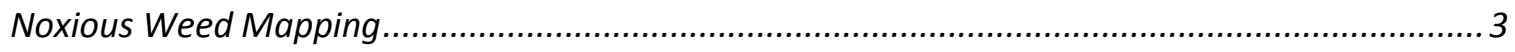

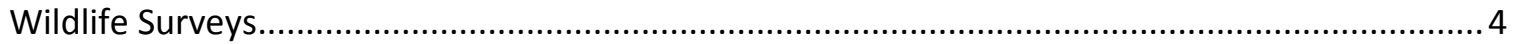

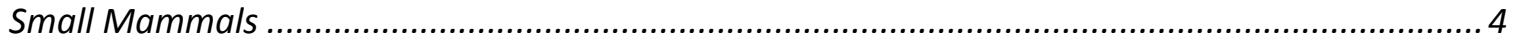

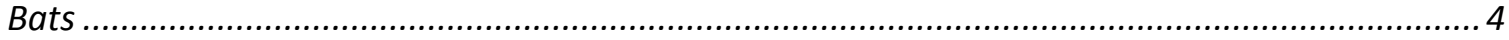

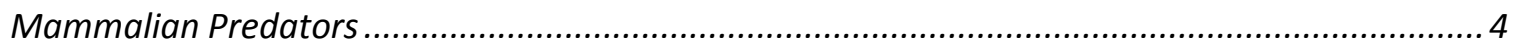

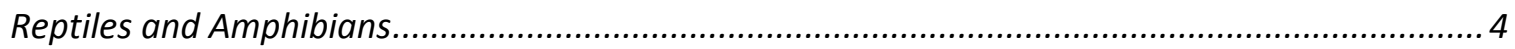

Owls

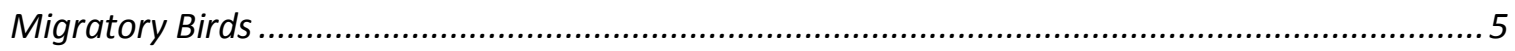

RESULTS

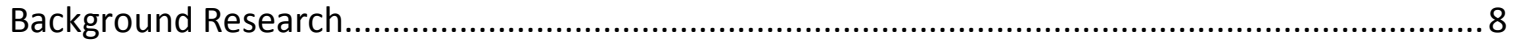

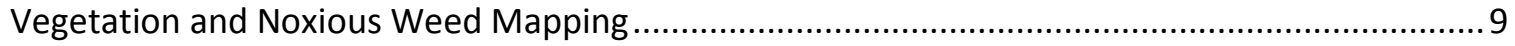

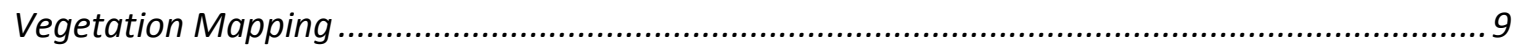

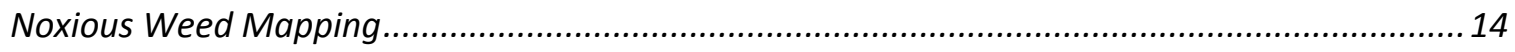

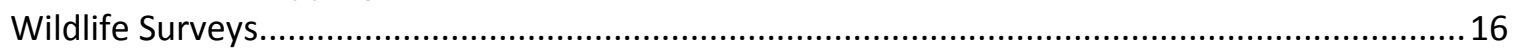

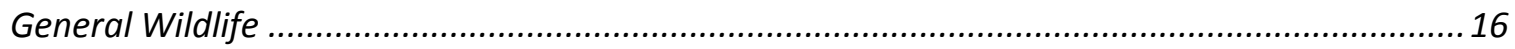

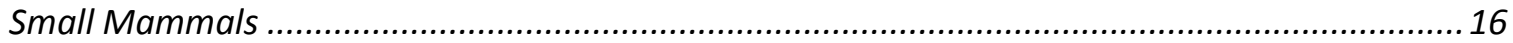

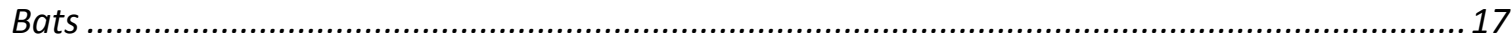

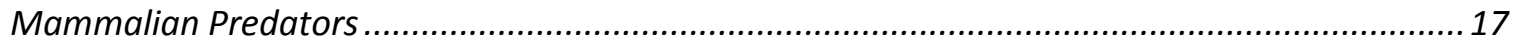

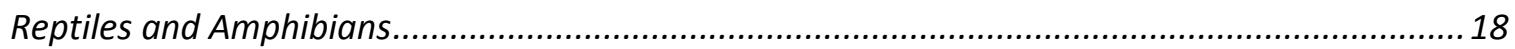

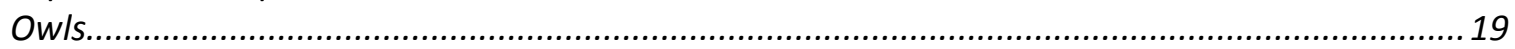

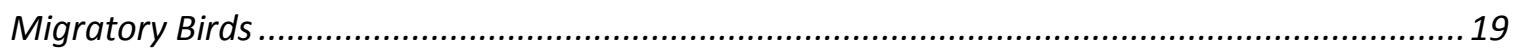

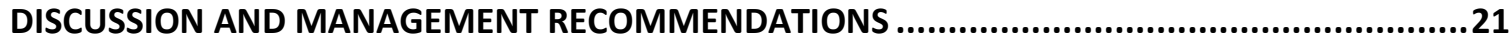

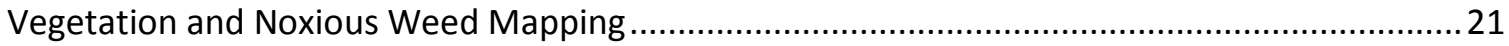

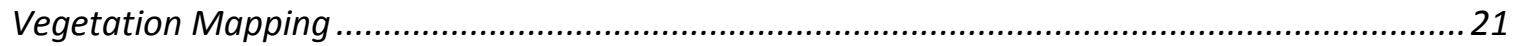

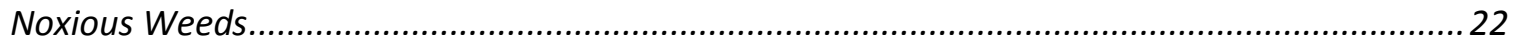

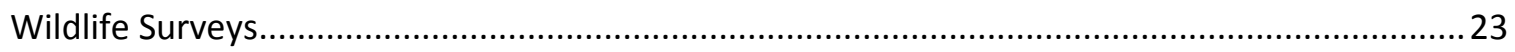

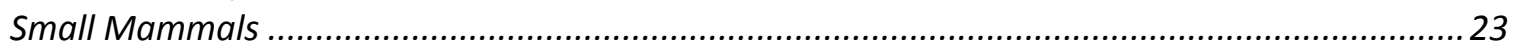

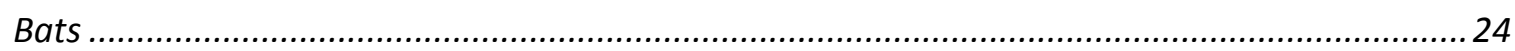

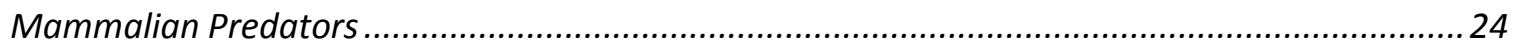

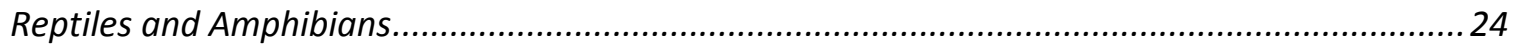

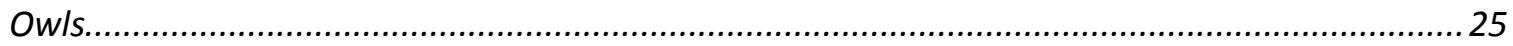

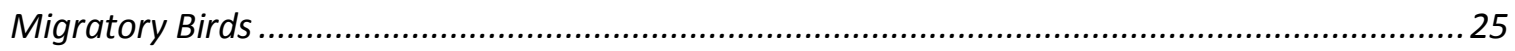

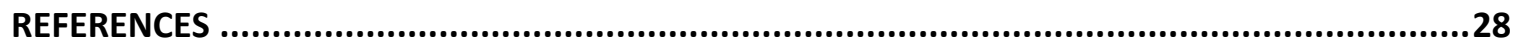

\section{Tables}

Table 1. Dominance categories of noxious weeds................................................................. 3 
Table 2. Rare and/or imperiled species and natural communities known from or likely to

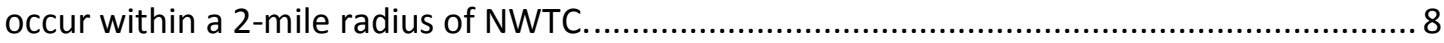

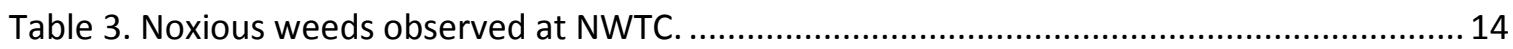

Table 4. Small mammal species captured within the NREL NWTC Area of Interest, August

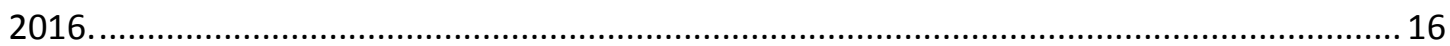

Table 5. Bat monitoring results conducted by NREL, 2015-2016................................................. 17

Table 6. Amphibian survey results from 2016 on the NWTC property....................................... 18

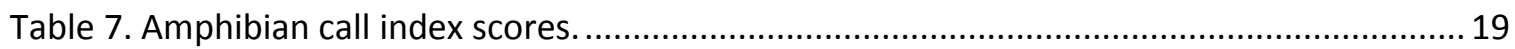

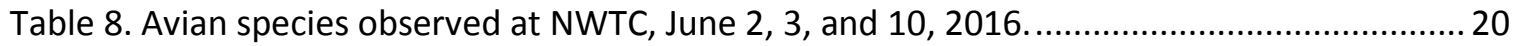

Table 9. Avian species observed at NWTC, September 2016.................................................. 21

Table 10. Comparison of diversity of bird species in NWTC, 2010-2011 and 2016.................... 21

Table 11. Comparison of small mammals species captured in NWTC, 2010-2011 and 2016........ 23

Table 12. Comparison of all bird species observed in NWTC, 2010-2011 and 2016................... 26

\section{Figures}

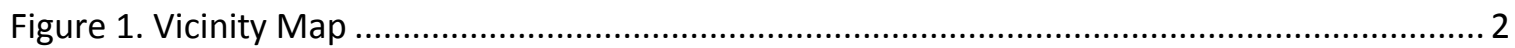

Figure 2. Small Mammal Trapping and Nocturnal Survey Locations at NWTC, August 2016......... 6

Figure 3. Avian Point Count Locations at NWTC, June and September 2016 ............................... 7

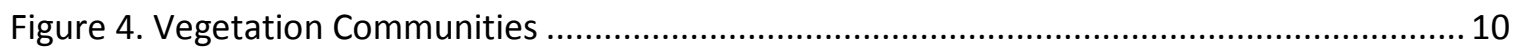

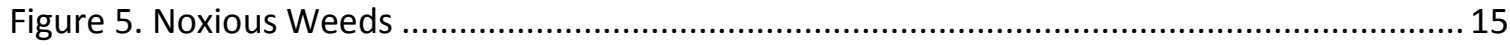

\section{Appendices}

Appendix A Vegetation Inventory Data Forms

Appendix B List of Species Observed During the 2016 Field Surveys

\section{Photos}

Photo Log 


\section{EXECUTIVE SUMMARY}

As part of the five-year monitoring update of its natural resources, the National Renewable Energy Laboratory (NREL) contracted with ERO Resources Corporation (ERO) to conduct avian, small mammal, amphibian, and vegetation surveys at the National Wind Technology Center (NWTC). This update to the baseline survey conducted in 2010-2011 will be used to evaluate and support National Environmental Policy Act (NEPA) analyses and assist in the management of natural resources at NWTC. NWTC is located on the boundary of Boulder and Jefferson Counties in Colorado (project area) and is part of the National Renewable Energy Laboratory (NREL), a laboratory of the U.S. Department of Energy (DOE). NWTC is operated by the Alliance for Sustainable Energy, LLC.

Since 1996, NREL has conducted wildlife and vegetation surveys at NWTC - in 1996, Monahan conducted a raptor study; in 2000, Plantae conducted a site characterization of all vegetation communities and noxious weeds found on-site; and in 2003, Schmidt et al. conducted a bird and bat use and fatality study. Most recently, Walsh (2011a) conducted a vegetation community and weed mapping survey along with small mammal, amphibian, and nocturnal owl surveys. Also in 2011, Tetra Tech, Inc. completed avian presence and bird and bat mortality surveys, while Walsh completed a separate bat study (Walsh 2011b).

In preparation for this monitoring report, ERO reviewed prior studies conducted by Walsh (2011a) and data from the Colorado Natural Heritage Program (CNHP 2016). Field data collection included vegetation and noxious weed mapping, live-trapping for small mammal presence, call-back surveys for nocturnal owl and amphibian presence, and point counts for detecting avian presence.

CNHP data revealed several rare and/or imperiled species potentially occurring at or within 2 miles of NWTC (CNHP 2016). One amphibian species of concern, the northern leopard frog (Lithobates pipiens), was heard during the 2016 surveys. No other wildlife species of concern were observed.

No rare or imperiled plant species or communities were observed during the 2016 surveys. The majority of vegetation at NWTC belongs to the xeric mixed grassland classification. Within that broad classification, ERO identified five distinct grassland community types, the largest and most widespread of which is the nonnative grassland community. Other mapped vegetation communities at NWTC include mixed grassland, disturbed native grassland, mixed yucca and nonnative grassland, degraded grassland, ponderosa pine woodland, mixed shrubland, palustrine emergent wetland, and riparian emergent wetland. Noxious weeds were identified and mapped.

General wildlife observed in conjunction with trapping and point count surveys included desert cottontail (Sy/vilagus audubonii), coyote (Canis latrans), mule deer (Odocoileus hemionus), and American elk (Cervus elaphus). Evening herpefauna surveys revealed western chorus frog (Pseudacris triseriata), Woodhouse's toad (Anaxyrus woodhousii), and northern leopard frog. One tiger salamander (Ambystoma tigrinum) larva was also observed. Small mammal trapping revealed 5 different species, with 92 individual mammals trapped on-site. A total of 30 different species of songbirds were observed 
on-site during summer 2016. In the process of conducting point counts, a variety of bird species were observed as flyovers including great egret (Ardea alba), great-horned owl (Bubo virginianus), common raven (Corvus corax), and double-crested cormorant (Phalacrocorax auritus).

Significant findings by ERO are:

- Nine vegetation community types were identified at NWTC; including five distinct grassland community types.

- A large wetland complex was observed that had previously been mapped as "mixed mesic grassland," indicating hydrology in this area has increased sufficiently enough from 2011 to support wetlands.

- Fourteen species on the Colorado Noxious Weed Lists were observed at NWTC. However, their abundance appears to have declined since 2011, particularly that of diffuse knapweed.

- The northern leopard frog was heard in wet areas adjacent to survey station A3 and at survey station A2 on the NWTC in 2016. This species had not been observed during previous baseline surveys and prior to 2015 was not known to occur at NWTC.

- Four out of six amphibian species that potentially occur within the NWTC property boundaries were documented during the 2016 surveys.

- Few large raptors were observed within and over the NWTC site, which could be due to the scarcity of perch and nest sites or other factors. American kestrels (Falco sparverius), which prey largely on small mammals, were observed frequently.

- The relatively high number of small mammals trapped on-site in 2016 reflects the high-quality small mammal foraging and breeding habitat at NWTC. The small mammal population likely supports several species of mammalian and avian predators.

- Avian species richness in 2016 was relatively high, which is consistent with previous findings. Species composition has changed since 2011 as follows:

- No horned larks (Eremophila alpestris) were observed in 2016, whereas they were among the most abundant species observed in 2011. This may be an indication of a shift in breeding habitat or a drop in population for this once widespread songbird, which has undergone a sharp decline throughout the United States in the last half century (Sauer et al. 2014).

- Killdeer (Charadrius vociferous) were observed during the 2016 surveys but not in the 2011 surveys. The presence of this species could indicate a subtle change in vegetative composition or structure. 


\section{INTRODUCTION}

The National Renewable Energy Laboratory (NREL) has been monitoring wildlife and vegetation characteristics at the National Wind Technology Center (NWTC) in Jefferson and Boulder Counties, Colorado since 1996. The most recent baseline surveys were conducted in 2010-2011 by Walsh (Walsh 2011a), Tetra Tech in 2010-2011 (Tetra Tech 2011). NWTC contracted ERO Resources Corporation (ERO) in 2016 to continue wildlife and vegetation monitoring in an effort to update the baseline wildlife and vegetation conditions present at the NWTC (Figure 1).

This report updates baseline conditions at the NWTC. Components of this work include sitewide surveys for vegetation, noxious weeds, small mammals, amphibians and reptiles, small owls, migratory birds, and bats.

The survey work achieved four main objectives:

1. Updated baseline conditions at the site (i.e., repeated previous surveys);

2. Compared results with 2011 wildlife and vegetation surveys and identified changes in vegetation communities and species composition (includes the Walsh and Tetra Tech surveys);

3. Provided supporting information for periodic National Environmental Policy Act (NEPA) analysis/documentation for NREL research activities; and

4. Identified high value or sensitive habitats where development impacts should be minimized.

\section{METHODS}

To provide effective and repeatable methods in the field, ERO reviewed species lists and adopted portions of methods described by Walsh (2011a). The 2010-2011 Vegetation and Wildlife Surveys at the National Renewable Energy Laboratory (Walsh 2011a) and the Avian Monitoring and Mortality Report (Tetra Tech 2011) were reviewed as part of the background research and fieldwork preparation for ERO's survey work at NWTC. ERO also reviewed Colorado Natural Heritage Program (CNHP) data for known locations of rare and/or imperiled plant and animal species at or within 2 miles of NWTC.

ERO completed wildlife and vegetation field surveys over a little more than three months (June through early September) in summer 2016. Vegetation and noxious weed surveys were conducted in early summer (June 21 and 22, 2016) and late summer (August 9, 2016) to account for differences in species flowering times. Point counts also were conducted during early and late summer to determine the presence of spring migrant and late summer/resident species (June 2, 3, and 10, 2016 and September 6 through 8,2016$)$. Small mammal live-trapping was conducted in mid-August to account for postbreeding season populations at the NWTC. Reptile, amphibian, and owl surveys were conducted the evenings of May 31 and June 2, 2016. 


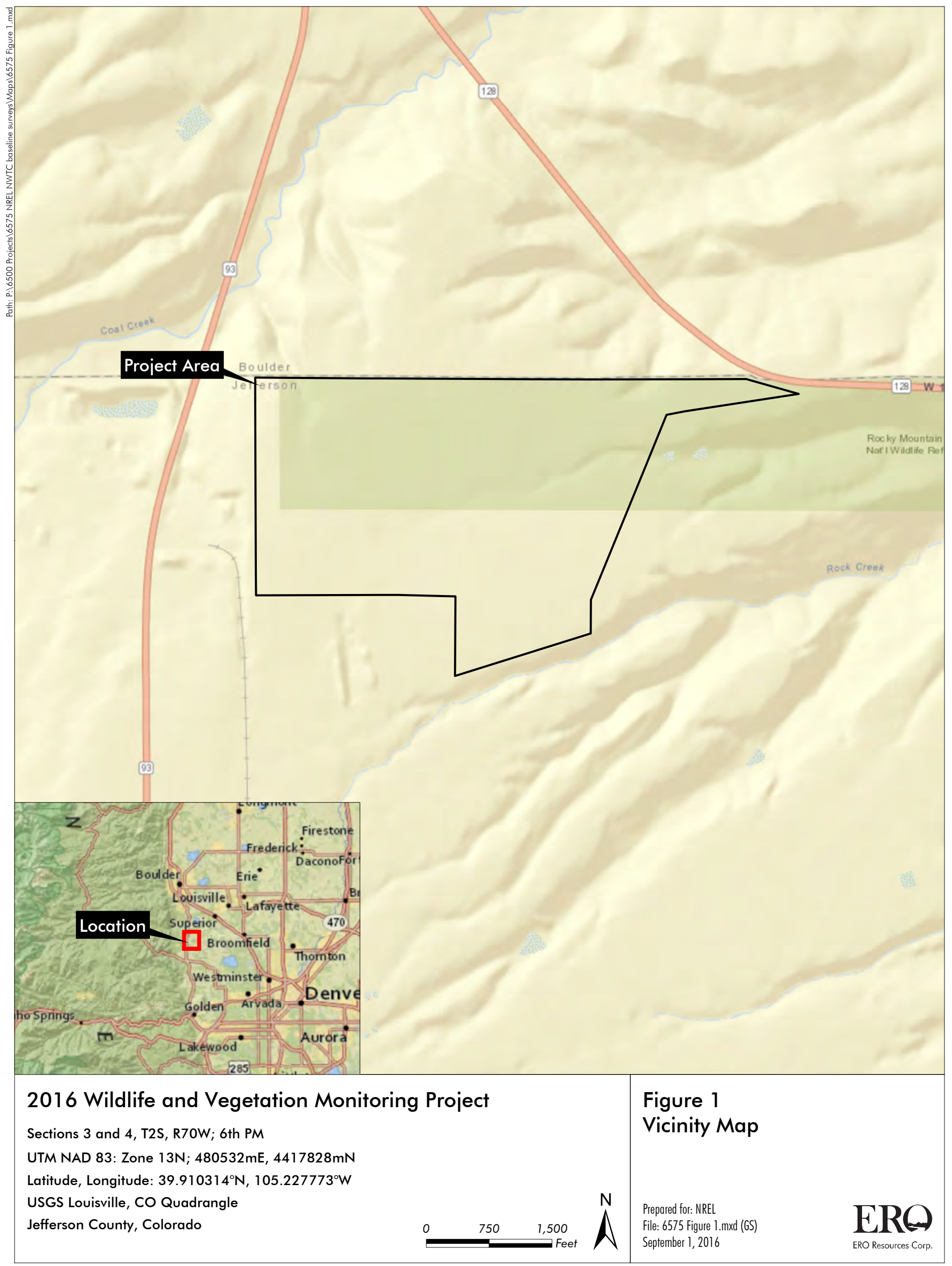

Portions of this document include intellectual property of ESRI and its licensors and are used herein under license. Copyright $\odot 2015$ ESRl and its licensors. All rights reserved.

This report is available at no cost from the National Renewable Energy Laboratory (NREL) at www.nrel.gov/publications 


\section{Vegetation and Noxious Weed Mapping}

\section{Vegetation Mapping}

ERO characterized the vegetation communities found at the NWTC site following a rapid assessment framework in which communities are differentiated by their species composition and structural layers. Emphasis was placed on dominant species when determining community boundaries. Prior to conducting fieldwork, ERO used aerial photography and topographic mapping to identify potential vegetation communities that would be ground-truthed during field surveys.

Surveyors walked meandering transects through the site to identify communities based on visual changes in species composition and structural layers. Vegetation inventory data forms were completed to document dominant species within each community (Appendix A). The data forms included visual estimates of relative species cover. The completed data forms reflect abundant and common species and are not a comprehensive species inventory. A list of all plant species observed during the surveys was compiled (Appendix B). Nomenclature follows PLANTS Database (U.S. Department of Agriculture/Natural Resource Conservation Service (USDA/NRCS) 2016).

To provide NREL with more information about isolated wetlands and seeps at NWTC, ERO conducted vegetation-based delineation and mapping of these communities. Formal U.S. Army Corps of Engineers jurisdictional delineation of wetlands was not conducted. ERO surveyed for occurrences of rare or imperiled plant species and communities during the vegetation mapping effort.

\section{Noxious Weed Mapping}

ERO mapped locations of noxious weeds that are listed on the State Noxious Weed Lists. During the 2016 weed surveys, emphasis was placed on areas previously identified by Walsh (2011a) as containing high-density populations of noxious weeds. Surveyors walked meandering transects throughout NWTC and locations of weeds were either drawn onto aerial photographs or mapped using a Global Positioning System (GPS) unit. High-density weed patches were mapped as individual polygons, while low-density and scattered populations are described and mapped at a broad scale. The density of noxious weed populations was estimated using the scale provided in Table 1. Noxious weed mapping was conducted concurrently with the vegetation community mapping.

Table 1. Dominance categories of noxious weeds.

\begin{tabular}{|c|l|c|}
\hline Dominance Category & \multicolumn{1}{|c|}{ Description } & Vegetative Cover \\
\hline 1 & Uncommon and scattered individuals & Less than $10 \%$ \\
\hline 2 & Infrequent and small populations & $10-20 \%$ \\
\hline 3 & Common, moderately dense populations & $20-50 \%$ \\
\hline 4 & Dominant within the community; dense populations & $50-80 \%$ \\
\hline 5 & Monotypic populations & Greater than $80 \%$ \\
\hline
\end{tabular}




\section{Wildlife Surveys}

Targeted surveys for small mammals, reptiles, amphibians, owls, and songbirds were conducted as outlined below. Observations of other wildlife, including small and large mammals and raptors, observed incidentally during targeted surveys were also recorded.

\section{Small Mammals}

Small mammal (rodent) live-trapping was conducted at six transect locations previously surveyed in 2010 and 2011 (Photo 1; Walsh 2011a). Transects were replicated to provide repeatability in analysis and allow comparison of results. These transects were selected to account for the small variation in vegetation communities found on-site. Over a period of 4 nights, 176 live-traps were set collectively, for a total of 704 trap nights. Traps were closed during daylight hours and opened shortly before sunset. All individual species captured were identified to genus and species, and age and sex were documented. Captured animals were marked on the right foot with nail polish. ERO conducted the trapping survey using protocol approved by the Animal Care and Use Committee of the American Society of Mammalogists from Guidelines of the American Society of Mammalogists for the Use of Wild Mammals in Research (Sikes 2016).

\section{Bats}

Acoustic recording devices were used to monitor bat activity at NWTC using a Song Meter SM2BAT+ at two locations; one at NWTC Site 4.4 met tower and on the Rocky Flats Refuge along the Lindsey Ranch tributary of Rock Creek. This effort was conducted by an NREL wildlife biologist and recording was conducted from mid-April to mid-September, 2015 in locations different than previous efforts (Walsh 2011a). The NWTC and the adjacent Rocky Flats Refuge are assumed to be within the roosting, foraging, and commuting ranges of bats in the general area and therefore observations at one site are likely at the other, limited only by specific habitats present. For example, the lack of trees on NWTC may limit roosting habitat, but not foraging habitat. Mist netting at NWTC and the Rocky Flats Refuge were conducted in 2016 under a separate effort (Rodriguez 2016).

\section{Mammalian Predators}

Observations of mammalian predators were made by the use of camera traps installed by NREL. Bushnell Model 119446 trophy trail cameras were used with unscented and scented posts within the field of view of the cameras. Cameras were set to deliver two photos within 2 seconds of each other once the camera sensor was triggered. Camera traps were located along the pine ridge in the northwestern portion of the NWTC and at the eastern boundary where the Rock Creek tributary crosses onto the Rocky Flats Refuge for the entire year, January 1, 2015 to December 31, 2015 and January 1, 2016 to September 15, 2016. These methods represent a monitoring effort greatly expanded from previous efforts (Walsh 2011a).

\section{Reptiles and Amphibians}

Nocturnal amphibian surveys were conducted on May 31 and June 2, 2016 using methods adapted from the U.S. Geological Survey Protocol (Droege 2010). Species were documented via vocalization and a 
calling index score was designated. Calling index scores range from 1 to 3 . An index score of 1 means that individual frog calls can be counted and there are quiet periods between calls. An index score of 2 means that calls of individual frogs can be counted - but there is some overlap, while an index score of 3 means that there is a full chorus of amphibian calls that are continuous and overlapping. Because amphibians are known to be attracted to roads at night, surveys also included searching roads in NWTC. Seven predesignated survey stations from 2011 surveys (Figure 2; Walsh 2011a) were visited near wetland areas in NWTC (A 1 through A7). Survey stations were visited 30 minutes after sunset over a period of two nights, instead of a period of three nights due to the late season start date.

Daytime surveys for reptiles and amphibians were conducted prior to nocturnal amphibian surveys and were focused on habitat features likely to be inhabited by reptiles or amphibians such as rocky outcrops, isolated wetlands, and riparian emergent wetland habitats. During the surveys, objects that could provide important habitat for amphibians and reptiles, such as logs, boards, and rocks, were searched. Amphibian habitat was surveyed for the presence of eggs, tadpoles, or adults. Any amphibians or reptiles observed were identified to species, and the general habitat in which they were found was recorded.

\section{Owls}

Nocturnal playback surveys for small owl species were conducted on May 31 and June 2, 2016 at three predesignated points from the 2011 surveys (Figure 2). Using methods adapted from Cilimburg (2007), a playback caller was used to attempt to locate any owls present in or near NWTC.

\section{Migratory Birds}

Songbird point counts were conducted in early summer and fall following methods adapted from Rocky Mountain Bird Observatory's 2009 point-transect protocol (Hanni et al. 2009). Previous point counts were conducted in 2010 and 2011. The six point count survey locations were replicated from the previous surveys (Figure 3; Photos 2 through 7). Points in 2010 and 2011 were assigned to allow for a survey within the various habitat types found in NWTC. Birds seen and heard at each point within a 20minute period once per morning were recorded. Species, age, sex, and number of individuals was noted. Sitewide diversity and evenness were estimated using the Shannon-Weiner Diversity Index and the Simpson's Index of Diversity. The Shannon-Weiner Index assumes that individuals are randomly sampled from an independent large population and all species are represented in the sample; this index is widely used for comparing diversity between various habitats (Hutchison 1970):

$$
H^{\prime}=\Sigma-\left(P_{i} * \ln P_{i}\right)
$$

Where $\mathrm{H}^{\prime}=$ Diversity Index; $\mathrm{P}=$ is the proportion of each species in the sample; $\ln \mathrm{P}_{\mathrm{i}}=$ natural $\operatorname{logarithm}$ of this proportion.

Typical values are generally between 1.5 and 3.5 in most ecological studies, and the index is rarely greater than 4 . The Shannon-Weiner index provides a simple synthetic summary of diversity and is most appropriate for comparing communities that do not differ greatly in richness. 







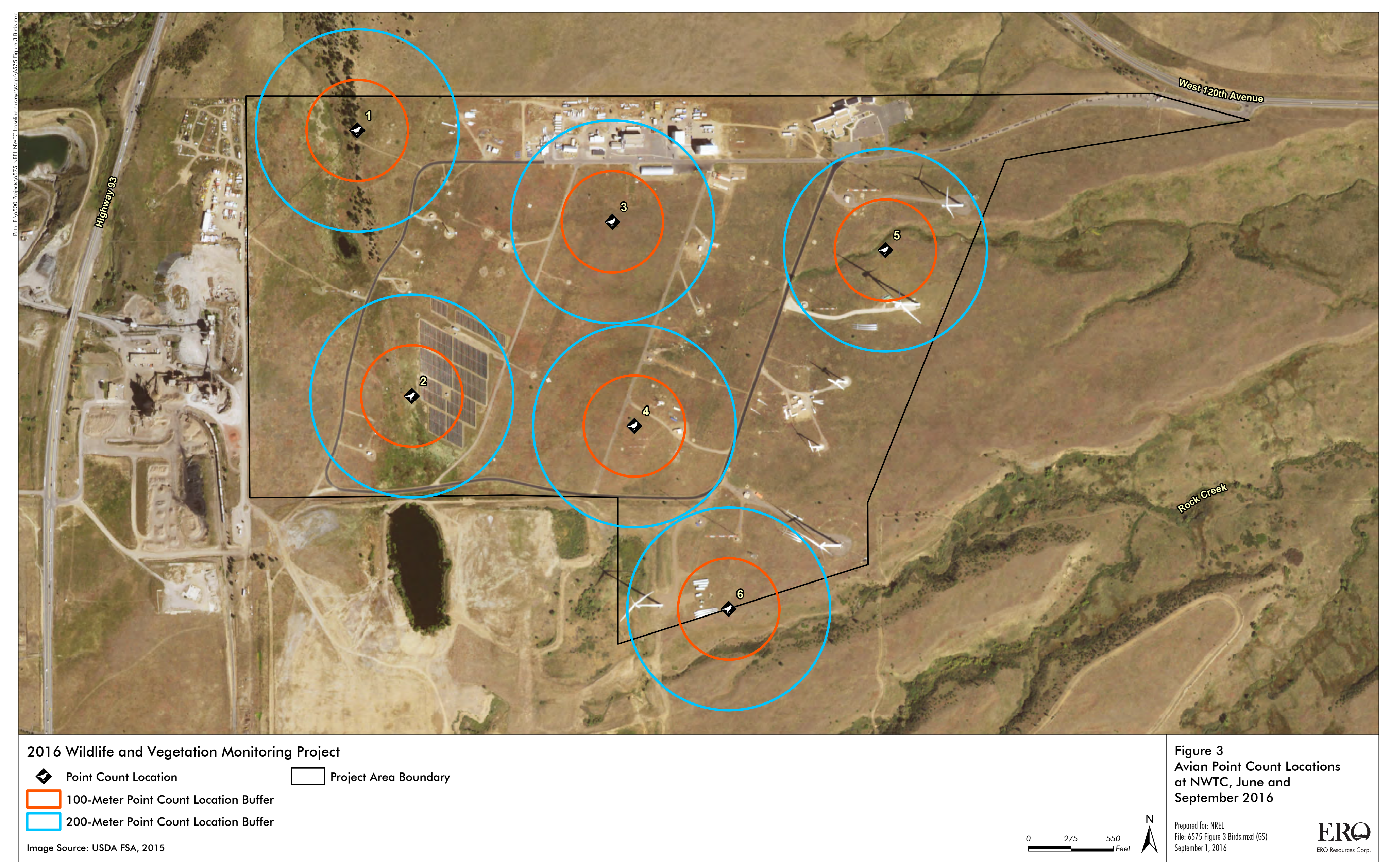


The Simpson's Index of Diversity measures the probability that two individuals randomly selected will belong to the same species (Peet 1975):

$$
D=1-\left\{\sum n(n-1) / N(N-1)\right\}
$$

Where $\mathrm{D}=$ Diversity index; $\mathrm{n}=$ the total number of birds of a particular species; and $\mathrm{N}=$ the total number of birds of all species.

The value of $D$ ranges between 0 and 1 , where 1 is complete equitability between the proportions of each species. Simpson's Index provides an intuitive proportional measure of diversity by giving more weight to the more abundant species in a sample and is much less sensitive to species richness.

The two diversity indices were calculated for the 2010-2011 and 2016 surveys to allow comparison in diversity between the two periods across all point count locations combined.

\section{RESULTS}

\section{Background Research}

Based on the CNHP database query, NWTC is within the Rocky Flats Grassland Network of Conservation Areas (NCA). The southeast section of NWTC is located within the Rocky Flats Potential Conservation Area (PCA). Within 2 miles of NWTC, 2 mammal, 3 bird, 1 amphibian, and 19 vascular plant species considered rare and/or imperiled have been documented (Table 2). Based on CNHP data, within NWTC, the ferruginous hawk (Buteo regalis), ottoe skipper (Hesperia ottoe), cross-line skipper (Polites origenes), and forktip three-awn (Aristada basiramea) are known or likely to occur within NWTC. The northern leopard frog was observed by NREL staff and ERO in NWTC and was not previously known to occur at this location.

Table 2. Rare and/or imperiled species and natural communities known from or likely to occur within a 2 -mile radius of NWTC.

\begin{tabular}{|l|l|}
\hline \multicolumn{1}{|c|}{ Scientific Name Common Name } \\
\hline MAMMALS & \multicolumn{1}{c|}{} \\
\hline Zapus hudsonius preblei & Preble's meadow jumping mouse \\
\hline Cynomys ludovicianus & Black-tailed prairie dog \\
\hline BIRDS & Bald eagle \\
\hline Haliaeetus leucocephalus & Ferruginous hawk* \\
\hline Buteo regalis* & Lewis's woodpecker \\
\hline Melanerpes lewis & \\
\hline AMPHIBIANS & Northern leopard frog \\
\hline Lithobates pipiens &
\end{tabular}


2016 Wildlife and Vegetation Monitoring Report

National Wind Technology Center

Jefferson County, Colorado

\begin{tabular}{|c|c|}
\hline Scientific Name & Common Name \\
\hline \multicolumn{2}{|l|}{ INSECTS } \\
\hline Speyeria idalia & Regal fritillary \\
\hline Atrytone arogos & Arogos skipper \\
\hline Callophrys mossii schryveri & Moss's elfin \\
\hline Erynnis martialis & Mottled dusky wing \\
\hline Hesperia ottoe* & Ottoe skipper* \\
\hline Polites origenes* & Cross-line skipper* \\
\hline Celastrina humulus & Hops feeding azure \\
\hline \multicolumn{2}{|l|}{ VASCULAR PLANTS } \\
\hline Amorpha nana & Dwarf wild indigo \\
\hline Carex oreocharis & Grassyslope Sedge \\
\hline Liatris ligulistylis & Meadow blazing star \\
\hline Mentzelia sinuata & Wavy-leaf stickleaf \\
\hline Aristada basiramea* & Forktip three-awn* \\
\hline Crataegus chrysocarpa & Yellow hawthorn \\
\hline Viola pedatifida & Prairie violet \\
\hline Oenothera coloradensis spp. coloradensis & Colorado butterfly plant \\
\hline Physaria vitulifera & Rydberg twinpod \\
\hline Spiranthes diluvialis & Ute ladies'-tresses orchid \\
\hline Carex saximontana & Rocky Mountain sedge \\
\hline Helianthemum bicknellii & Hoary frostweed \\
\hline \multicolumn{2}{|l|}{ NATURAL COMMUNITIES } \\
\hline Andropogon gerardii-Schizachyrium scoparium & Xeric tallgrass prairie \\
\hline Hesperostipa neomexicana & Great Plains mixed grass prairie \\
\hline Populus angustifolia/Salix irrorata & Foothills riparian woodland \\
\hline Pinus ponderosa/Cercocarpus montanus/Andropogon gerardii & Foothills ponderosa pine scrub woodlands \\
\hline
\end{tabular}

*Rare and/or imperiled species known or likely to occur within NWTC.

New species since 2011 are indicated in bold.

Source: CNHP 2016.

\section{Vegetation and Noxious Weed Mapping}

\section{Vegetation Mapping}

ERO identified nine vegetation community types within NWTC (Figure 4). Descriptions of vegetation communities are provided below. The majority of NWTC can broadly be described as xeric mixed grassland (Walsh 2011a). These areas are largely dominated by introduced pasture grasses including Kentucky bluegrass (Poa pratensis), Canada bluegrass (Poa compressa), and smooth brome (Bromus inermis). Common native species include purple threeawn (Aristida purpurea), big bluestem (Andropogon gerardii), and switchgrass (Panicum virgatum). To provide NREL with greater detail on the grasslands at NWTC, ERO identified five distinct grassland community types that are discussed in greater detail below. Several changes in the vegetation communities were observed since NWTC was last mapped (Walsh 2011a). Specific changes are discussed by community type. 





A total of 19 vegetation inventory data forms were completed and are provided in Appendix A. Locations corresponding to individual data forms are shown on Figure 4 . A list of all species observed during the 2016 field surveys is provided in Appendix B. This list is not comprehensive and primarily reflects abundant or common species. No rare or imperiled plant species or vegetation communities were observed during the 2016 field surveys (Table 2).

\section{Nonnative Grass/and}

The nonnative grassland community is the most common community type at NWTC (Photo 8). This community is dominated by introduced pasture grasses including smooth brome, Kentucky bluegrass, and Canada bluegrass. Nonnative species make up 65 to 90 percent of the vegetative cover in this community. Commonly observed forb species include alyssum (Alyssum simplex), Canada horseweed (Conyza canadensis), fringed sage (Artemisia frigida), prairie sage (Artemisia ludoviciana), scurfpea (Psoralidium tenuiflorum), and hairy golden aster (Heterotheca villosa). Native grasses within this community, particularly big bluestem and switchgrass, occur most frequently along roadside depressions. This may be due to higher soil moisture as a result of the roadsides capturing precipitation runoff. Datasheets $8,12,14,18$, and 19 correspond to this community type (Appendix A).

\section{Mixed Grassland}

This community is distinguished from the nonnative grassland community by the higher cover of native grasses and forbs (Photo 9). Native species typically make up 50 to 60 percent of the vegetative cover.

Common grasses in this community include smooth brome, Kentucky bluegrass, Canada bluegrass, big bluestem, little bluestem, switchgrass, and purple threeawn. Common forbs in this community include scurfpea, fringed sage, prairie sage, and hairy golden aster. Datasheets 15 and 17 correspond to this community type.

\section{Disturbed Native Grassland}

This community occurs along the northern fence line of NWTC. Total vegetative cover in this community ranges from 30 to 70 percent, and exposed soil in this community consists of coarse gravel. The proximity of this community to machinery and buildings, the abundance of exposed ground, and the gravelly soil texture indicate that this area has been significantly disturbed by human activity. However, this community had the highest vegetative cover of native grasses within NWTC (Photo 10). This community is dominated by purple threeawn, big bluestem, and switchgrass. Other commonly observed species in this community include nonnative grasses, such as smooth brome, and ruderal weed species including annual sunflower (Helianthus annuus), prickly lettuce (Lactuca serriola), common mullein (Verbascum thapsus), and bigbract verbena (Verbena bracteata). Datasheet 9 corresponds to this community type.

\section{Mixed Yucca and Nonnative Grassland}

This community is very similar in composition to the nonnative grassland community; however, it is distinguished by the presence of stands of yucca (Yucca glauca) shrubs (Photo 11). Yucca typically occurs 
as scattered individuals throughout the grassland communities at the NWTC. In the areas identified as mixed yucca and nonnative grassland, yucca occurs at a higher density than in the surrounding grassland, and the structural change from the surrounding grasslands warrants its inclusion as a separate community. Dominant grass species in this community include downy brome (Bromus tectorum), smooth brome, Kentucky bluegrass, and intermediate wheatgrass (Thinopyrum intermedium). Datasheet 2 corresponds to this community type.

\section{Degraded Grassland}

The degraded grassland community has been heavily influenced by human disturbance and is dominated by nonnative and noxious grass species with minimal native vegetation (typically less than 10 percent) (Photo 12). The dominant species in this community are downy brome and intermediate wheatgrass. Downy brome is a List C Noxious Weed in Colorado. Near the southwest corner of the NWTC is an area containing significant bare soil that is dominated by annual and biennial weed species including kochia (Bassia scoparia), downy brome, and common sunflower (Photo 13). The soil in this area has a distinctive red color that is visible on recent aerial imagery. The degraded grassland community along the western boundary of the NWTC is possibly influenced by historic and ongoing disturbance that originates from off-site activities. Datasheets 3, 4, and 16 correspond to this community type.

\section{Ponderosa Pine Woodland}

This community occurs along a granite outcrop located in the northwestern corner of the project area (Photo 14). Dominant tree and shrub species include ponderosa pine (Pinus ponderosa), skunkbrush sumac (Rhus trilobata), wax currant (Ribes cereum), and wild plum (Prunus americana). Understory vegetation consists of native and nonnative grass and forb species. Common species include smooth brome, crested wheatgrass (Agropyron cristatum), junegrass (Koeleria macrantha), sulphur cinquefoil (Potentilla recta), golden banner (Thermopsis rhombifolia), harebell (Campanula rotundifolia), and James' nailwort (Paronychia jamesii). Previous surveys of NWTC indicated that a large and dense population of diffuse knapweed (Centaurea diffusa), a List B noxious weed, occurred in this community (Plantae 2000; Walsh 2011a). ERO observed diffuse knapweed within this community as low-density patches and scattered individuals. Datasheet 7 corresponds to this community type.

\section{Mixed Shrubland}

The mixed shrubland community occurs on the southeast end of the same granite outcrop that supports the ponderosa pine woodland. The southeast end of this outcrop is lower and less exposed than where the ponderosa pine woodland occurs. Dominant shrub species include wax currant, skunkbrush sumac, chokecherry (Prunus virginiana), and western serviceberry (Amelanchier alnifolia) (Photo 15). This community supports higher cover and diversity of native grasses and forbs than the surrounding nonnative grassland community. Common grasses in this community include smooth brome, Kentucky bluegrass, big bluestem, junegrass, and sideoats grama (Bouteloua curtipendula). Common forbs include scurfpea, prairie sage, golden banner, hairy golden aster, and sulphur flower (Eriogonum umbellatum). Datasheet 5 corresponds to this community type. 


\section{Palustrine Emergent Wetland}

ERO identified six wetlands within NWTC that fall into the palustrine emergent category (Cowardin et al. 1979). Dominant species in this community type include broadleaf cattail (Typha latifolia), Arctic rush (Juncus arcticus), common spikerush (Eleocharis palustris), and Nebraska sedge (Carex nebrascensis). Other commonly observed species include foxtail barley (Hordeum jubatum), Torrey's rush (Juncus torreyi), cloaked bulrush (Scirpus pallidus), and willowherb (Epilobium) species. Patches of smooth brome, Kentucky bluegrass, big bluestem, and western wheatgrass (Pasocpyrum smithii) occur on the fringes of these wetland communities.

A large palustrine emergent wetland (PEM) occurs south of the solar array in Row 1 (Photo 16). The southernmost road separates this large wetland from a second smaller wetland located along the southern fence line of NWTC. These wetlands appear to be hydrologically connected and supported by seepage from a reservoir located south of the property boundary. Capture of surface water runoff may provide additional hydrology to these wetlands. The large wetland north of the road was previously identified by Plantae (2000); however, Walsh (2011a) mapped this area as "mixed mesic grassland" dominated by big bluestem. Hydrological support has evidently increased since 2011 as this area was dominated by obligate wetland species and surface water was present throughout the area during the 2016 field surveys. Datasheet 1 corresponds to this wetland.

A second large PEM occurs in a seasonal pond located southwest of the ponderosa pine woodland community (Photo 17). Walsh (2011a) indicated that wetlands at this location depend on an elevated spring and early summer water table to support the wetland community. ERO observed standing water in the pond during both of the 2016 field surveys. Dominant species in this wetland are common spikerush and broadleaf cattail. Canada bluegrass is the dominant grass species in the uplands adjacent to this wetland community. Canada thistle (Cirsium arvense) and common mullein, both noxious weeds, were abundant on the west-facing slope above the pond. Datasheet 6 corresponds to this community.

A third large PEM occurs south of the solar array in Row 3 (Photo 18). This wetland consists of a large stand of cattails (Typha species) and foxtail barley surrounded by sandbar willow (Salix exigua) and plains cottonwood (Populus deltoides) trees. Datasheet 13 corresponds to this community type.

Two small PEMs occur on slopes along the northern boundary of the project area. The first PEM is located in the northwest corner of NWTC (Photo 19), and the second occurs along the northern fence line adjacent to the parking lot of the administration and engineering building in the northeast portion of NWTC. Dominant species in the westernmost wetland are Nebraska sedge and Arctic rush. Prairie cordgrass and Arctic rush are dominant in the easternmost wetland. These wetlands occur on gentle slopes and appear to be supported by ground water seeps. Both of these wetlands were previously identified and mapped by Walsh (2011a). The community type for these two wetlands is most similar to datasheets 1 and 6 . 


\section{Riparian Emergent Wetland}

Riparian emergent wetland communities occur within the two prominent drainages located in the eastern half of NWTC (Figure 4; Photos 20 and 21). Both drainages show evidence of intermittent flow. The northernmost drainage is a tributary to Coal Creek, and the southern drainage is a tributary to Rock Creek. Dominant species within these wetlands include Arctic rush, foxtail barley, Nebraska sedge, and prairie cordgrass (Spartina pectinata). Significant patches of Canada thistle, bull thistle (Cirsium vulgare), and common teasel (Dipsacus fullonum), all List B noxious weeds, occur within the northernmost drainage. Other observed species include shortbeak sedge (Carex brevior), swordleaf rush (Juncus ensifolius), longstyle rush (Juncus longistylis), Torrey's rush, common spikerush, and switchgrass. Occasional plains cottonwood trees and sandbar willow shrubs occur along these drainages. Datasheets 10 and 11 correspond to this community type.

\section{Noxious Weed Mapping}

Locations of noxious weeds are shown on Figure 5, and a complete list of noxious weeds observed during the 2016 field surveys is provided below (Table 3). Downy brome, Canada thistle, common mullein, and musk thistle (Carduus nutans) were the most commonly observed noxious weed species at NWTC. Areas of high-density downy brome are captured in the degraded grassland community mapping (Figure 5). In general, noxious weeds occurred in a scattered low-density pattern throughout the project area. Dense patches of Canada thistle, bull thistle, and common teasel were observed within the large riparian drainage located east of the parking lot of the administration and engineering building (Photo 22). Dense patches of common mullein were observed on slopes in the vicinity of the seasonal pond, the ponderosa pine woodland, and the two large riparian drainages. Sulphur cinquefoil was only observed within the ponderosa pine woodland. Recent efforts to control diffuse knapweed appear to largely be successful. Diffuse knapweed was only observed in scattered low-density patches throughout the project area.

Table 3. Noxious weeds observed at NWTC.

\begin{tabular}{|l|l|l|}
\hline \multicolumn{1}{|c|}{ Common Name } & \multicolumn{1}{c|}{ Scientific Name } & \multicolumn{1}{c|}{ Status } \\
\hline Bull thistle & Cirsium vulgare & List B \\
\hline Canada thistle & Cirsium arvense & List B \\
\hline Common mullein & Verbascum thapsus & List C \\
\hline Common St. Johnswort & Hypericum perforatum & List C \\
\hline Common teasel & Dipsacus fullonum & List B \\
\hline Dalmation toadflax & Linaria dalmatica & List B \\
\hline Diffuse knapweed & Centaurea diffusa & List B \\
\hline Downy brome & Bromus tectorum & List B \\
\hline Field bindweed & Convolvulus arvensis & List C \\
\hline Moth mullein & Verbascum blattaria & List B \\
\hline Musk thistle & Carduus nutans & List B \\
\hline Quackgrass & Elymus repens & List C \\
\hline Redstem filaree & Erodium cicutarium & List C \\
\hline Sulphur cinquefoil & Potentilla recta & List B \\
\hline
\end{tabular}




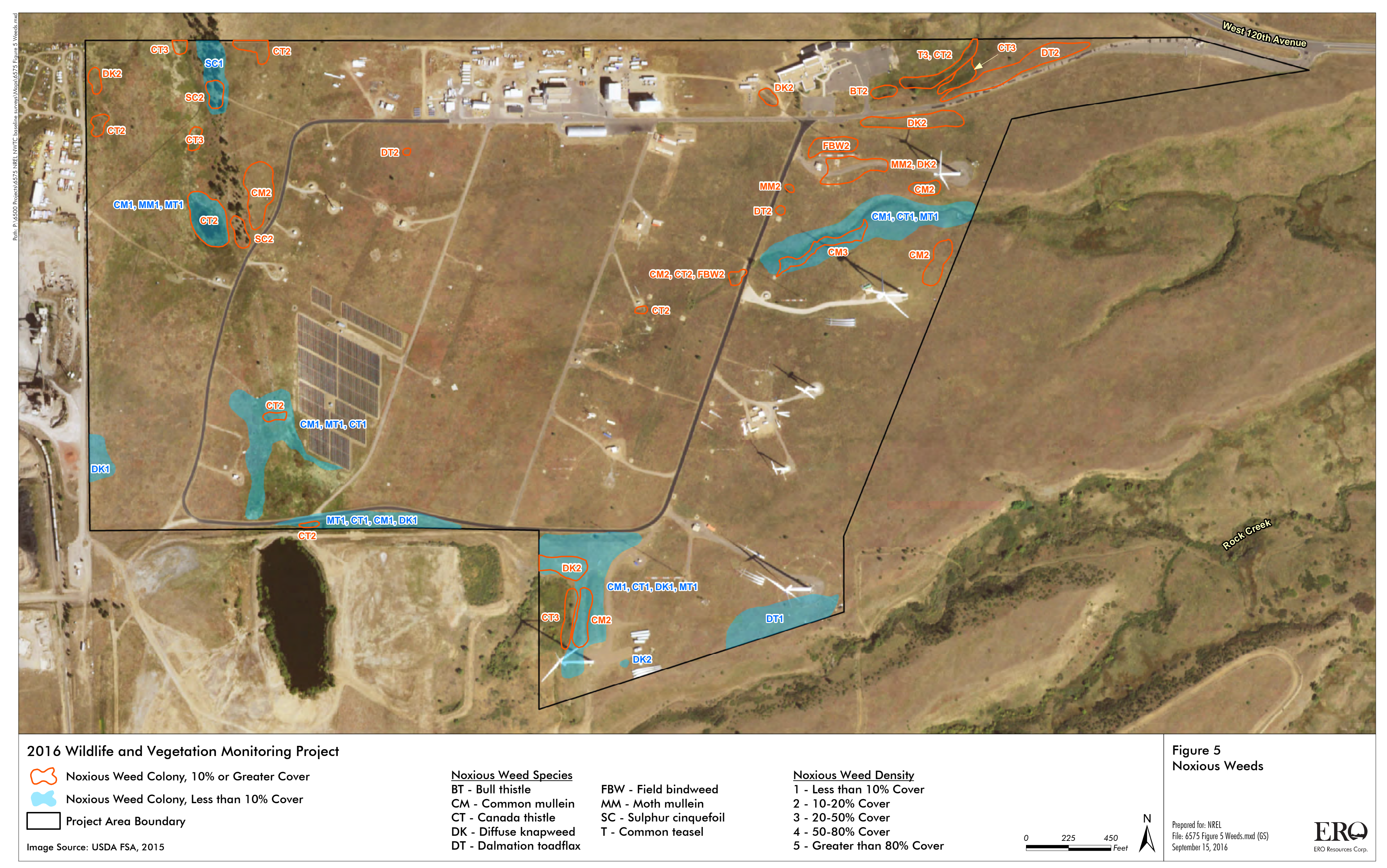




\section{Wildlife Surveys}

\section{General Wildlife}

Wildlife observed incidentally at NWTC during targeted surveys included desert cottontail (Sy/vilagus audubonii), coyote (Canis latrans), mule deer (Odocoileus hemionus), and American elk (Cervus elaphus). These species had been previously observed on-site. American elk were observed with calves in June 2016 in NWTC, photographed with trail cameras in July, August, and September, and observed calling in early September 2016 in the area directly south of NWTC. In the process of conducting point counts, a variety of bird species were observed as flyovers including great egret (Ardea alba), common raven (Corvus corax), and double-crested cormorant (Phalacrocorax auritus).

\section{Small Mammals}

Small mammal trapping was conducted over a period of 4 nights, resulting in a total of 704 trap nights during late summer (August) of 2016. Trapping revealed 5 different species of small mammals, with 92 individual mammals trapped on-site (Table 4). Deer mice (Peromyscus maniculatus) were the most common species trapped, followed by meadow voles (Microtus pennsylvanicus). Four of the captured species were observed in previous surveys, with the exception of the least shrew (Cryptotis parva) found along a wet seep located in the northwest section of NWTC. This shrew was found with worn teeth, indicating an older individual. A total of 19 recaptures were recorded (deer mice and meadow voles).

Table 4. Small mammal species captured within the NREL NWTC Area of Interest, August 2016.

\begin{tabular}{|c|c|c|}
\hline Species & Total & Recaptured \\
\hline Deer mouse (Peromyscus maniculatus) & 83 & 16 \\
\hline Female Adult & 32 & \\
\hline Female Juvenile & 15 & \\
\hline Male Adult & 24 & \\
\hline Male Juvenile & 12 & \\
\hline Meadow vole (Microtus pennsylvanicus) & 18 & 3 \\
\hline Female Adult & 6 & \\
\hline Female Juvenile & 1 & \\
\hline Male Adult & 9 & \\
\hline Male Juvenile & 2 & \\
\hline Prairie vole (Microtus ochrogaster) & 3 & 0 \\
\hline Female Adult & 1 & \\
\hline Female Juvenile & 0 & \\
\hline Male Adult & 2 & \\
\hline Male Juvenile & 0 & \\
\hline Mexican woodrat (Neotoma Mexicana) & 6 & 0 \\
\hline Least shrew (Cryptotis parva) & 1 & 0 \\
\hline Female Adult & 1 & \\
\hline TOTAL & 111 & \\
\hline
\end{tabular}

Deer mice captures resulted in a greater number of females ( 56 percent) than males ( 44 percent), with a total of 50 percent juveniles (both females and males). Captures of meadow voles resulted in a greater 
number of males (61 percent) than females (39 percent), with a total of 16 percent juveniles (both females and males). Woodrats were not sexed due to difficulty of handling.

\section{Bats}

Bat acoustic monitoring was conducted by NREL in 2015 and mist netting was conducted by Zotz Ecological Consulting (Rodriguez 2016). Seven species of bats have been observed at NWTC and the Rocky Flats Refuge using a combination of continuous acoustic monitoring and mist netting (Table 5). The species of myotis that are known to inhabit this region (Adams 2003) include western small-footed myotis (Myotis ciliolabrum), western long-eared myotis (Myotis evotis), little brown myotis (Myotis lucifugus), and long-legged myotis (Myotis volans).

No federal- or state-listed threatened, endangered, or candidate species or species of special concern were positively identified during surveys (USFWS 2016; CPW 2016).

Table 5. Bat monitoring results conducted by NREL, 2015-2016.

\begin{tabular}{|c|c|c|c|c|}
\hline Species & $\begin{array}{c}\text { Acoustic } \\
\text { Monitoring at } \\
\text { NWTC, } 2015\end{array}$ & $\begin{array}{l}\text { Mist Netting at } \\
\text { NWTC and Rocky } \\
\text { Flats Refuge, } \\
2016\end{array}$ & $\begin{array}{l}\text { Observed by } \\
\text { Walsh } 2011\end{array}$ & $\begin{array}{c}\text { Observed by } \\
\text { Schmidt et } \\
\text { al. } 2003\end{array}$ \\
\hline $\begin{array}{l}\text { Western small-footed myotis (Myotis } \\
\text { ciliolabrum) }\end{array}$ & $\mathrm{X}$ & $x$ & & $x$ \\
\hline Western long-eared myotis (Myotis evotis) & & & $P$ & \\
\hline Little brown myotis (Myotis lucifugus) & $\mathrm{x}$ & $\mathrm{X}$ & $x$ & $\mathrm{X}$ \\
\hline Fringed myotis (Myotis thysanodes) & & $\mathrm{X}$ & $x$ & \\
\hline Long-legged myotis (Myotis volans) & & & $\mathrm{P}$ & $x$ \\
\hline Eastern red bat (Lasiurus borealis) & $\mathrm{X}$ & $x$ & $x$ & \\
\hline Hoary bat (Lasiurus cinereus) & $\mathrm{x}$ & $\mathrm{X}$ & $\mathrm{X}$ & $\mathrm{X}$ \\
\hline Silver-hair bat (Lasionycteris noctivagans) & $\mathrm{x}$ & $x$ & $\mathrm{x}$ & $x$ \\
\hline Big brown bat (Eptesicus fuscus) & $\mathrm{X}$ & $\mathrm{X}$ & $\mathrm{x}$ & \\
\hline $\begin{array}{l}\text { Townsend's big-eared bat (Corynorhinus } \\
\text { townsendii) }\end{array}$ & $P$ & & & \\
\hline $\begin{array}{l}\text { Mexican (Brazilian) free-tailed bat } \\
\text { (Tadarida brasiliensis) }\end{array}$ & $\mathrm{P}$ & & & $\mathrm{P}$ \\
\hline
\end{tabular}

$\mathrm{P}$ - Possible occurrence, but not confirmed.

\section{Mammalian Predators}

Coyotes were observed at the scented and unscented camera traps during all seasons sampled. A bobcat was observed periodically in April and July at scented camera trap locations and only at night. In August 2015, a mountain lion was photographed moving through the pine ridge area at night.

Other non-predator observations in 2015 and 2016 include elk and mule deer. A white-tailed deer was also observed in the spring of 2016. 


\section{Reptiles and Amphibians}

Nocturnal amphibian surveys at NWTC revealed the presence of three frog species and one salamander species - western chorus frog (Pseudacris triseriata), Woodhouse's toad (Anaxyrus woodhousii), northern leopard frog (Lithobates pipiens), and tiger salamander (Ambystoma tigrinum). During the May 31, 2016 surveys, western chorus frog adults, tadpoles, and egg masses were identified visually or aurally at six of the seven listening stations at NWTC. No other amphibian species were detected on May 31, 2016. On June 2, 2016, western chorus frog, northern leopard frog, and Woodhouse's toad were all heard calling simultaneously from a pond located immediately southwest of call station A3. A larval tiger salamander was also observed in the same pond. Additionally, western chorus frogs and a single northern leopard frog were heard calling near a small pond in the northwestern portion of NWTC (near call station A2). Adult western chorus frogs and Woodhouse's toads were also visually identified on June 2. Table 6 summarizes the results of amphibian surveys conducted on May 31 and June 2, 2016. Table 7 shows calling index scores recorded during surveys.

Table 6. Amphibian survey results from 2016 on the NWTC property.

\begin{tabular}{|l|l|l|l|l|}
\hline \multicolumn{1}{|c|}{ Common Name } & \multicolumn{1}{|c|}{ Call Station } & \multicolumn{1}{c|}{ Date } & \multicolumn{1}{c|}{ Detection Method } & \multicolumn{1}{c|}{ Life Stage } \\
\hline Western chorus frog & A2, A3, A4, A5, A6, A7 & $5-31-16$ & Aural & Adult \\
\hline Western chorus frog & A5 & $5-31-16$ & Visual & Adult \\
\hline Western chorus frog & A2, A3, A5 & $5-31-16$ & Visual & Tadpole \\
\hline Western chorus frog & A5 & $5-31-16$ & Visual & Egg mass \\
\hline Western chorus frog & A2 & $6-2-16$ & Visual & Adult, tadpoles \\
\hline Northern leopard frog & A2, A3 & $6-2-16$ & Aural & Adult \\
\hline Woodhouse's toad & A3 & $6-2-16$ & Aural & Adult \\
\hline Woodhouse's toad & $\begin{array}{l}\text { On road between A3 } \\
\text { and A4 }\end{array}$ & $6-2-16$ & Visual & Adult \\
\hline Tiger salamander & Pond southwest of A3 & $6-2-16$ & Visual & Larva \\
\hline
\end{tabular}


2016 Wildlife and Vegetation Monitoring Report National Wind Technology Center Jefferson County, Colorado

Table 7. Amphibian call index scores.

\begin{tabular}{|c|c|c|}
\hline Station & Species Identified* & Index Score ${ }^{1}$ \\
\hline \multicolumn{3}{|c|}{ May 31, 2016} \\
\hline A1 & $\mathrm{N} / \mathrm{A}$ & 0 \\
\hline A2 & Western chorus frog & $2-3$ \\
\hline A3 & Western chorus frog & 2 \\
\hline A4 & Western chorus frog & 3 \\
\hline A5 & Western chorus frog & 3 \\
\hline A6 & Western chorus frog & 2 \\
\hline A7 & Western chorus frog & 1 \\
\hline \multicolumn{3}{|c|}{ June 2, 2016} \\
\hline A1 & $\mathrm{N} / \mathrm{A}$ & 0 \\
\hline $\mathrm{A} 2$ & Western chorus frog; Northern leopard frog & $\mathrm{WCF}=3 ; \mathrm{NOLF}=1$ \\
\hline A3 & Western chorus frog; Woodhouse's toad & $\mathrm{WCF}=2 ; \mathrm{WT}=1$ \\
\hline A4 & Western chorus frog; Northern leopard frog; Woodhouse's toad & $\mathrm{WCF}=3 ; \mathrm{NOLF}=3 ; \mathrm{WT}=3$ \\
\hline A5 & Western chorus frog & 3 \\
\hline A6 & Western chorus frog & 2 \\
\hline A7 & Western chorus frog & 1 \\
\hline
\end{tabular}

${ }^{*} \mathrm{~N} / \mathrm{A}-$ no amphibians detected; ${ }^{1}$ Index Scores: 0 = no calling heard; 1 =individual calls with silence between calls; $2=$ individual calls with overlap between calls; $3=$ Full chorus with constant overlap between calls.

WCF $=$ western chorus frog.

NOLF $=$ northern leopard frog.

WT $=$ Woodhouse's toad.

A single snake was photographed by NWTC staff on June 27, 2016 after the field survey date. ERO later identified the snake as an eastern yellow-bellied racer (Coluber constrictor). NREL staff also observed a painted turtle crossing the main access road on June 7, 2015 and northern leopard frogs in a wetland area in the southwest part of the NWTC in October 2015 (see Palustrine Emergent Wetlands in the Vegetation section).

\section{Owls}

During June 2016, nocturnal surveys revealed no owl species via callback method. One great-horned owl was observed at NWTC during an early morning point count. A great-horned owl was photographed at the pine ridge camera trap location.

\section{Migratory Birds}

Early summer point counts revealed 30 species of birds within NWTC (Table 8). Of these species, western meadowlarks were the most prevalent songbird, followed by vesper sparrows and red-winged blackbirds. During the second point survey conducted in early September, 18 bird species were observed primarily through visual detection due to the late season time frame (Table 9). In September, the most common bird found was the barn swallow, followed by the western meadowlark, vesper sparrow, and black-billed magpie. In total, 242 individual birds were heard or seen in June and 180 individual birds were observed in September. 
2016 Wildlife and Vegetation Monitoring Report

National Wind Technology Center

Jefferson County, Colorado

Table 8. Avian species observed at NWTC, June 2, 3, and 10, 2016.

\begin{tabular}{|c|c|c|c|}
\hline Common Name & Scientific Name & Code & Total \\
\hline American kestrel & Falco sparverius & AMKE & 6 \\
\hline American robin & Turdus migratorius & AMRO & 1 \\
\hline Barn swallow & Hirundo rustica & BARS & 13 \\
\hline Black-billed magpie & Pica hudsonia & BBMA & 16 \\
\hline Blue-grey gnatcatcher & Polioptila caerulea & BGGN & 4 \\
\hline Brewer's blackbird & Euphagus cyanocephalus & BRBL & 4 \\
\hline Broad-tailed hummingbird & Selasphorus platycercus & BTAH & 1 \\
\hline Bullock's oriole & Icterus bullockii & BUOR & 1 \\
\hline Canada goose & Branta canadensis & CANG & 1 \\
\hline Common nighthawk & Chordeilis minor & CONI & 1 \\
\hline Common raven & Corvus corax & CORA* & 1 \\
\hline Double-crested cormorant & Phalacrocorax auritus & $\mathrm{DCCO}^{*}$ & 3 \\
\hline European starling & Sturnus vulgaris & EUST & 3 \\
\hline Grasshopper sparrow & Ammodramus savannarum & GRSP & 1 \\
\hline Great egret & Ardea alba & GREG* & 4 \\
\hline Great-horned owl & Bubo virginianus & GHOW & 1 \\
\hline Green-tailed towhee & Pipilo chlorurus & GTTO & 5 \\
\hline House wren & Troglodytes aedon & HOWR & 5 \\
\hline Killdeer & Charadrius vociferous & KILL & 8 \\
\hline Lark sparrow & Chondestes grammacus & LASP & 1 \\
\hline Mourning dove & Zenaida macroura & MODO & 4 \\
\hline Red-winged blackbird & Agelaius phoeniceus & RWBL & 23 \\
\hline Say's phoebe & Sayornis saya & SAPH & 11 \\
\hline Spotted towhee & Pipilo maculatus & SPTO & 14 \\
\hline Unidentified duck & & UNDU* & 1 \\
\hline Vesper sparrow & Pooecetes gramineus & VESP & 35 \\
\hline Western kingbird & Tyrannus verticalis & WEKI & 12 \\
\hline Western meadowlark & Sturnella neglecta & WEME & 59 \\
\hline Western wood pewee & Contopus sordidulus & WEWP & 1 \\
\hline Wilson's snipe & Gallinago delicata & WISN & 2 \\
\hline TOTAL & & & 242 \\
\hline
\end{tabular}

*Birds observed flying through NWTC. 
Table 9. Avian species observed at NWTC, September 2016.

\begin{tabular}{|l|l|l|l|}
\hline \multicolumn{1}{|c|}{ Common Name } & \multicolumn{1}{|c|}{ Scientific Name } & \multicolumn{1}{c|}{ Code } & \multicolumn{1}{c|}{ Total } \\
\hline American kestrel & Falco sparverius & AMRO & 1 \\
\hline American robin & Turdus migratorius & BARS & 51 \\
\hline Barn swallow & Hirundo rustica & BBMA & 18 \\
\hline Black-billed magpie & Pica hudsonia & BRBL & \multicolumn{1}{c|}{1} \\
\hline Brewer's blackbird & Euphagus cyanocephalus & BTAH & 1 \\
\hline Broad-tailed hummingbird & Selasphorus platycercus & CANG & 10 \\
\hline Canada goose & Branta canadensis & DCCO* & 3 \\
\hline Double-crested cormorant & Phalacrocorax auritus & EUST & \\
\hline European starling & Sturnus vulgaris & GRCA & 2 \\
\hline Gray catbird & Dumetella carolinensis & LASP & 5 \\
\hline Lark sparrow & Chondestes grammacus & MODO & 1 \\
\hline Mourning dove & Zenaida macroura & REHA & 13 \\
\hline Red-tailed hawk & Buteo jamaicensis & SAPH & 2 \\
\hline Say's phoebe & Sayornis saya & SOSP & 12 \\
\hline Song sparrow & Melospiza melodia & UNFI* & 1 \\
\hline Unidentified finch* & & VESP & 9 \\
\hline Vesper sparrow & Pooecetes gramineus & WEME & 18 \\
\hline Western meadowlark & Sturnella neglecta & 21 \\
\hline TOTAL & & 180 \\
\hline
\end{tabular}

*Birds observed flying through NWTC.

The Shannon -Weiner diversity index and the Simpson's diversity index were calculated for the 2010/2011 surveys and the 2016 surveys and are shown below (Table 10).

Table 10. Comparison of diversity of bird species in NWTC, 2010-2011 and 2016.

\begin{tabular}{|l|c|c|}
\hline \multicolumn{1}{|c|}{ Diversity Index } & Years & Results \\
\hline Shannon-Weiner Index & 2016 & $\mathrm{H}^{\prime}=2.77$ \\
\hline & $2010-11$ & $\mathrm{H}^{\prime}=2.92$ \\
\hline Simpson's Index & 2016 & $\mathrm{D}=0.91$ \\
\hline & $2010-11$ & $\mathrm{D}=0.93$ \\
\hline
\end{tabular}

\section{DISCUSSION AND MANAGEMENT RECOMMENDATIONS}

\section{Vegetation and Noxious Weed Mapping}

\section{Vegetation Mapping}

The vegetation communities observed during the 2016 field surveys were largely consistent with previous mapping efforts (Walsh 2011a). The majority of NWTC consists of nonnative grasslands dominated by introduced pasture grasses such as smooth brome, Kentucky bluegrass, and Canada bluegrass. Patches of native grasses, such as big bluestem and switchgrass, occur throughout the project area, particularly along roadsides where soil moisture may be higher than in surrounding areas. The palustrine emergent and riparian emergent wetland communities typically had greater species diversity than the surrounding grasslands. The wetland communities also provide important habitat for amphibian species found at NWTC. The mixed shrubland and ponderosa pine woodlands contained the 
greatest diversity of forbs at NWTC and these communities provide important habitat for wildlife, particularly songbird species. The above communities should be protected from future development or disturbance and efforts should be made to encourage native vegetation within these communities.

Degraded grasslands, which are dominated by downy brome, occur along the western boundary of NWTC and are the result of historic and ongoing disturbances caused by off-site activities. Restoring degraded grassland areas and increasing the cover of native vegetation would benefit the surrounding grassland communities. Downy brome can be controlled through mechanical means such as grazing, tilling, or prescribed burn strategies. Chemical control can also be effective but may not be desirable for large populations. If cheatgrass has been established for several years the soil will likely have a large bank of cheatgrass seeds, and as a result, these strategies will require intensive control and reseeding efforts to prevent reestablishment of cheatgrass (Colorado Natural Areas Program 1998). Ongoing disturbance from off-site activities may make restoration of these communities challenging.

ERO identified a large PEM wetland south of the large solar array at NWTC. This wetland complex was previously identified by Plantae (2000); however, Walsh (2011a) indicated this area had dried substantially and that it consisted of a big bluestem-dominated grassland at the time of that study. The presence of wetlands at this location during the 2016 field surveys indicates that hydrology has increased substantially since 2011 . The hydrological regime of this wetland appears to be dynamic, and installation of ground water wells at this location would facilitate long-term monitoring of these fluctuations.

To date, the vegetation studies at NWTC have been largely qualitative in design. As a result, discussions of changes to the vegetation must be broad in nature. Future quantitative studies would facilitate more detailed discussions of long-term vegetation trends at NWTC. Establishing a series of permanent monitoring transects throughout the vegetation communities of NWTC, such as point-intercept transects, would provide an efficient and repeatable method of measuring changes in vegetation cover and community composition over time.

\section{Noxious Weeds}

ERO observed 14 noxious weed species at NWTC. No List A species were observed during the 2016 field surveys. In general, weeds occur in low-density patches or as scattered individuals. High-density patches of common teasel and Canada thistle were concentrated within the riparian drainages. Large patches of common mullein occurred on the slopes above the riparian drainages and on the slopes above the seasonal pond. Recent weed-control efforts appear to have largely been successful at reducing the density of weed populations, particularly populations of diffuse knapweed. Walsh (2011a) identified a high-density population of diffuse knapweed within the ponderosa pine woodland. During the 2016 field surveys, diffuse knapweed was observed throughout the site as scattered individuals or in low-density patches. At a minimum, ERO recommends continuing the current weed-control program at NWTC. Additional weed-control efforts within the riparian drainages would be beneficial to reduce the highdensity populations of common teasel and Canada thistle at these locations. Increasing weed control within the ponderosa pine woodland community would also be beneficial. This community had higher 
forb diversity than the surrounding grasslands and reducing competition from noxious weeds would help support the diversity of native forbs and grasses. In most cases, combining weed treatments with reseeding efforts is more effective than weed control alone, and using a more comprehensive restoration approach on specific communities and locations at NWTC may greatly improve the overall habitat quality and ecological integrity of the site.

\section{Wild life Surveys}

Wildlife incidentally observed during the 2016 field surveys had been previously observed at NWTC during the 2011 surveys. The observation of bugling elk (Cervus canadensis) in the vicinity of NWTC, along with the presence of young in early June within NWTC and photographs from trail cameras in July, August, and September, indicate that elk use NWTC and the surrounding area for mating grounds. This is not unexpected due the known presence of elk on the Rocky Flats National Wildlife Refuge southeast of NWTC.

\section{Small Mammals}

Live-trapping of small mammals resulted in a capture rate of 27 percent with a total of 92 individuals captured from five different species, indicating that small mammals are abundant in NWTC. Transects located near seeps and drainages (T5 and T6) resulted in the greatest diversity of small mammals, suggesting that the presence of water and tall vegetation cover not present in the other transects supports a wider variety of species and should be protected.

Deer mice and meadow voles were prevalent and these species were also observed in previous surveys. A single least shrew was trapped along a seep, which was the first documented occurrence on-site. Based on tooth wear, the shrew was likely about one year old. Colorado is the western limit of the distribution of the least shew, and they are not considered rare on the Colorado Piedmont from Denver to Fort Collins. The least shrew probably is a fairly recent arrival in Colorado and the current distribution of this shrew may be a consequence of perennially moist habitats created by irrigation and riparian vegetation associated with flood control (Armstrong 1972). Compared with previous studies conducted in 2010-2011 (Walsh 2011a), small mammal species composition was generally similar with a few differences - masked shrews and western harvest mice were captured in 2010 and 2011, respectively, and not in 2016, whereas a least shrew was captured in 2016 (Table 11).

Table 11. Comparison of small mammals species captured in NWTC, 2010-2011 and 2016.

\begin{tabular}{|l|c|c|}
\hline \multicolumn{1}{|c|}{ Species } & $\mathbf{2 0 1 0 - 2 0 1 1}$ & $\mathbf{2 0 1 6}$ \\
\hline Deer mouse (Peromyscus maniculatus) & $\checkmark$ & $\checkmark$ \\
\hline Least shrew (Cryptotis parva) & $\mathbf{x}$ & $\checkmark$ \\
\hline Masked shrew (Sorex cinereus) & $\checkmark$ & $\mathrm{x}$ \\
\hline Meadow vole (Microtus pennsy/vanicus) & $\checkmark$ & $\checkmark$ \\
\hline Mexican woodrat (Neotoma Mexicana) & $\checkmark$ & $\checkmark$ \\
\hline Prairie vole (Microtus ochrogaster) & $\checkmark$ & \\
\hline Western harvest mouse (Reithrodontomys megalotis) & $\checkmark$ \\
\hline
\end{tabular}

$\checkmark=$ species captured, $\boldsymbol{x}=$ species not captured. 
Overall, the success of trapping can depend on a number of factors, such as evening and morning temperatures, precipitation, and ease of trap activation. Weather during the trapping session was mostly mild, with a few scattered rain showers in the evening, and likely had a minor influence on trapping success.

\section{Bats}

Seven species of bats have been observed on or adjacent to the NWTC and have had their calls recorded on the NWTC. The only exception is the fringed myotis which has not been recorded on NWTC but has been captured there. These seven species make up the typical bat community at NWTC and either roost or forage at the site with the eastern red bat occurring only occasionally (Adams 2003). Other species are probable as presented in Table 5 with the Townsend's big-eared bat being the only species of concern that could potentially frequent the NWTC. These bats are most often found at higher elevations and are associated with caves or abandoned mines where they roost daily and hibernate.

All species observed by Walsh (Walsh 2011b), were observed in 2016 with mist netting efforts helping to confirm these species, especially Myotis species, in the area. Myotis calls are very similar and are difficult to differentiate. For example, the Walsh Bat Survey Report (Walsh 2011b) suspected that fringed myotis were present but did not get representative calls recorded and could not conclude that these bats were present.

\section{Mammalian Predators}

Camera traps on NWTC helped to reveal coyotes and bobcats that are rarely observed. Coyotes were photographed day and night, all months of the year and are the primary mammalian predator at NWTC. Occasionally, a bobcat was observed (April and July) but only at night.

\section{Reptiles and Amphibians}

Four amphibian species were identified during field surveys on May 31, 2016 and June 2, 2016 - western chorus frog, northern leopard frog, Woodhouse's toad, and tiger salamander. During the May 31, 2016 field survey, all life stages (egg masses, larval, and adult) of the western chorus frog were observed in a wetland near survey station A5 and were heard calling at six of the seven listening stations (A2 through A7). No other amphibian species were detected during the May 31, 2016 field survey. On June 2, 2016, western chorus frog, northern leopard frog, Woodhouse's toad, and a tiger salamander larva were identified. Chorus frogs, northern leopard frogs, and Woodhouse's toads were heard calling simultaneously from a pond southwest of survey station A3. Additionally, two adult Woodhouse's toads were also identified on roads on the NWTC between 9:30 and 10:30 p.m.

Northern leopard frogs were not recorded on NWTC prior to 2015. This amphibian, although not currently listed as threatened or endangered by the U.S. Fish and Wildlife Service, is experiencing declines in populations and range due to the introduction of invasive species, habitat degradation, overharvesting, and disease (U.S. Fish and Wildlife Service 2009). The northern leopard frog is considered a state species of concern and its protection should be considered in future NWTC land use decisions. 
Amphibian diversity on the NWTC is relatively high for this location in Colorado. There are a total of six native species of amphibian that potentially occur in this portion of the county. In addition to the four species observed during the 2016 surveys, only the plains spadefoot toad (Spea bombifrons) and the Great Plains toad (Anaxyrus cognatus) have the potential to occur on the NWTC, and were not documented during the 2016 surveys.

No reptiles were observed during the 2016 field surveys. NWTC staff have observed at least five reptile species in the past including (painted turtle (Chrysemys picta), garter snake (Thamnophis sp.), eastern yellow-bellied racer (Coluber constrictor), western rattlesnake (Crotalus viridis), and bullsnake (Pituophis catenifer). Several other species including mountain short-horned lizard (Phrynosoma hernandesi), sixlined racerunner (Aspidoscelis sexlineata), and central plains milksnake (Lampropeltis triangulum) potentially occur on the NWTC property.

Numerous factors, including climate change, expansion of invasive species into NWTC, and surrounding changes in land use such as increased commercial and residential development, could contribute to changes in species composition - especially amphibian species which are declining worldwide (Gascon et al. 2005). Conducting future surveys may reveal changes in species composition or overall abundance over time.

The widest variety of reptiles and amphibians were observed in wetlands, ponds, streams and rocky outcrops. Establishing a buffer around sensitive habitats such as wetlands, rock outcrops, streams, and ponds where development or disturbance would be avoided would help preserve herpetile diversity.

\section{Owls}

Prior to ERO's work at the NWTC, NREL staff reported an owl perching on a utility building and one perching on a fence post west of the pine ridge area at NWTC (Ryon, pers. comm. 2016). Owl pellets had also been found at the base of a utility building on-site. During a point count in June, a great-horned owl was seen flying from the direction of the building across NWTC to a tree just outside the boundary to the south. This owl is most likely hunting on or near the site.

\section{Migratory Birds}

NWTC supports a rich diversity of birds, with songbirds making up the majority of the species. The point counts conducted by ERO during the mid-summer and early fall resulted in a total of 30 different species of birds, both migratory and resident. Tetra Tech's 2010/2011 surveys were conducted in all seasons for one year, whereas the 2016 field surveys were conducted only once in early summer and once in late summer. The differences in duration and frequency of the surveys limit direct comparison of the data, but comparison of values for the Shannon -Weiner diversity index and Simpson's diversity index gives some indication of the relative diversity and species composition. Values for both diversity indices were comparable between the 2010/2011 surveys and the 2016 surveys (Table 10) and demonstrate that species diversity at NWTC is relatively high and the numbers of individuals of all species were evenly distributed. The similar number of different species in late spring/early summer surveys by ERO and Tetra Tech shows a consistency in viable habitat and resources available to local grassland and migratory 
2016 Wildlife and Vegetation Monitoring Report

National Wind Technology Center

Jefferson County, Colorado

birds. Of the 6 point count locations in ERO's June 2016 survey, the greatest diversity of migratory birds was recorded in the mixed shrubland and ponderosa pine woodlands (Point 1) located in the northwest part of the NWTC; this area provides a patch of tree cover amidst a predominantly grassland community in an area where grasslands are dominated by grasslands predominantly grassland community. If possible, disturbance of the mixed shrubland and ponderosa pine woodlands should be avoided to preserve the ecological integrity of the NWTC

The survey conducted in September 2016 yielded a total of 18 different species and a total of 180 individual birds, compared with a total of 205 individual birds observed in fall 2010. The difference in the number of birds observed is likely the result of differences in frequency and duration of surveys. ERO completed 3 consecutive mornings in early September, while the previous survey was completed over the course of 12 mornings in September and October 2010.

Of the species observed during the 2010/2011 and 2016 surveys, 30 were unique to either the 2010/2011 or 2016 survey period, suggesting a possible shift in species composition at NWTC (Table 12). In 2016, most bird species using the site for breeding were likely observed during the early June surveys; however, an additional survey earlier in the season (i.e., late May) in future studies would allow observation of more migratory birds. Additional surveys during fall and winter would also allow a more complete evaluation of bird use of NWTC and a more thorough analysis of site-specific trends. Numerous factors, including climate change, expansion of invasive species into NWTC, and surrounding changes in land use, could contribute to changes in species composition. Comparing vegetation structure over time may also reveal some potential sources of change in species composition.

Table 12. Comparison of all bird species observed in NWTC, 2010-2011 and 2016.

\begin{tabular}{|l|c|c|}
\hline \multicolumn{1}{|c|}{ Species } & $\mathbf{2 0 1 0 - 2 0 1 1}$ & $\mathbf{2 0 1 6}$ \\
\hline American kestrel & $\checkmark$ & $\mathbf{x}$ \\
\hline American crow & $\checkmark$ & $\mathbf{x}$ \\
\hline American goldfinch & $\checkmark$ & $\checkmark$ \\
\hline American robin & $\checkmark$ & $\mathbf{x}$ \\
\hline American tree sparrow & $\checkmark$ & $\checkmark$ \\
\hline Barn swallow & $\checkmark$ & $\checkmark$ \\
\hline Black-billed magpie & $\checkmark$ & $\mathbf{x}$ \\
\hline Black-capped chickadee & $\mathbf{x}$ & $\checkmark$ \\
\hline Blue-grey gnatcatcher & $\checkmark$ & $\mathbf{x}$ \\
\hline Brewer's blackbird & $\checkmark$ & $\checkmark$ \\
\hline Brewer's sparrow & $\checkmark$ & $\checkmark$ \\
\hline Broad-tailed hummingbird & $\mathbf{x}$ & $\checkmark$ \\
\hline Bullock's oriole & $\mathbf{x}$ & $\mathbf{x}$ \\
\hline Canada goose & $\checkmark$ & $\checkmark$ \\
\hline Chipping sparrow & $\mathbf{x}$ & $\checkmark$ \\
\hline Common nighthawk & $\checkmark$ & $\mathbf{x}$ \\
\hline Common raven & $\checkmark$ & $\checkmark$ \\
\hline Dark-eyed junco & $\checkmark$ & \\
\hline Double-crested cormorant & $\checkmark$ & \\
\hline Downy woodpecker & & \\
\hline
\end{tabular}


2016 Wildlife and Vegetation Monitoring Report

National Wind Technology Center

Jefferson County, Colorado

\begin{tabular}{|c|c|c|}
\hline Species & $2010-2011$ & 2016 \\
\hline Eurasian collared dove & $\checkmark$ & $x$ \\
\hline European starling & $\checkmark$ & $\checkmark$ \\
\hline Grasshopper sparrow & $\checkmark$ & $\checkmark$ \\
\hline Gray catbird & $\checkmark$ & $\checkmark$ \\
\hline Great egret & $x$ & $\checkmark$ \\
\hline Great-horned owl & $x$ & $\checkmark$ \\
\hline Green-tailed towhee & $x$ & $\checkmark$ \\
\hline Horned lark & $\checkmark$ & $x$ \\
\hline House finch & $\checkmark$ & $\checkmark$ \\
\hline House wren & $x$ & $\checkmark$ \\
\hline Killdeer & $x$ & $\checkmark$ \\
\hline Lark sparrow & $x$ & $\checkmark$ \\
\hline Loggerhead shrike & $\checkmark$ & $x$ \\
\hline Mountain chickadee & $\checkmark$ & $x$ \\
\hline Mourning dove & $\checkmark$ & $\checkmark$ \\
\hline Northern flicker & $\checkmark$ & $x$ \\
\hline Red winged blackbird & $\checkmark$ & $\checkmark$ \\
\hline Red-tailed hawk & $\checkmark$ & $\checkmark$ \\
\hline Sandhill crane & $\checkmark$ & $x$ \\
\hline Say's phoebe & $\checkmark$ & $\checkmark$ \\
\hline Sharp-shinned hawk & $\checkmark$ & $x$ \\
\hline Song sparrow & $\checkmark$ & $\checkmark$ \\
\hline Spotted towhee & $x$ & $\checkmark$ \\
\hline Townsends solitaire & $\checkmark$ & $x$ \\
\hline Tree swallow & $\checkmark$ & $x$ \\
\hline Vesper sparrow & $\checkmark$ & $\checkmark$ \\
\hline Western kingbird & $\checkmark$ & $\checkmark$ \\
\hline Western meadowlark & $\checkmark$ & $\checkmark$ \\
\hline Western wood pewee & $x$ & $\checkmark$ \\
\hline Wilson's snipe & $x$ & $\checkmark$ \\
\hline
\end{tabular}

$\checkmark=$ bird present, $\mathbf{x}=$ bird absent.

The most notable difference between the 2010 and 2016 surveys was the total lack of horned larks in 2016. Horned larks were observed during all seasons in 2011, with the highest mean use occurring during summer. Horned larks are year-round residents of Colorado and are social birds, foraging in pairs or small groups during the breeding season, and are sometimes found in huge flocks outside of the breeding season (Beason 1995). They are considered numerous but their populations throughout the United States have declined by 71 percent since 1966 (Sauer et al. 2014). The horned lark was noted as a Common Bird in Steep Decline in the 2014 State of the Birds Report (North American Bird Conservation Initiative 2014). Overall, the declining trend in population is not fully understood.

Species abundance varies seasonally and from year to year and is influenced by a multitude of local and regional factors, including precipitation, disease, etc. Larks prefer bare ground in open space with very short or no vegetation, including bare agricultural ground. Subtle changes in vegetative structure that may have occurred at NWTC since 2011 could be a contributing factor to the absence of horned larks in 2016. It is also possible that horned larks may be avoiding the wind turbines. Shaffer and Buhl (2015) 
found that seven of the nine grassland species they studied in North Dakota (which did not include horned larks) avoided wind turbines. However; Johnson et al. (2000) found that horned lark use of turbine plots in Minnesota was higher than expected, while in Oregon (Erickson et al. 2004) found no evidence that horned larks were either attracted to or displaced by wind turbines. The analysis of the distribution of horned larks with respect to wind turbines at NWTC conducted by Walsh (2011) was limited by a small sample size. Based on the information available for NWTC, it is not possible to draw any conclusions about the effects of wind turbines on horned larks at NWTC.

A bird present in 2016 but absent from NWTC in 2011 is the killdeer. This plover often observed far from beaches and shorelines is considered common in open ground with low or no vegetation (Jackson and Jackson 2000). The presence of killdeer in 2016 is an indication that they are making use of the bare ground areas and dirt roads in NWTC that may have increased from 2011. Shaffer et al. (2016) found that killdeer densities increased nearest to newly constructed turbines, which probably reflects their attraction to the associated habitat disturbance.

Relatively few large raptors were observed within and around NWTC, which could be due to the lack of suitable perches or nesting habitat. Another possibility is that raptors are avoiding the wind turbines; Tetra Tech recorded low encounter rates in their 2010/2011 surveys. American kestrels were commonly observed during surveys. This small falcon hunts for insects and small mammals in open territory and perches on wires or poles, all of which are prevalent in the NWTC (Smallwood and Bird, 2002). The kestrel is the most common and widespread falcon in North America but populations have declined $66 \%$ since 1966 (NABCl, 2014). Current declines stem from clearing of land and felling of snags these birds depend on for nesting, loss of prey sources due to "clean" farming practices which remove hedgerows, trees, and brush, and exposure to pesticides, which can reduce clutch size and hatching success and destroy insects and other prey species (USGS 2014). Available prey and perch sites at NWTC support what appears to be a healthy American kestrel population.

\section{REFERENCES}

Adams, R.A. 2003. Bats of the Rocky Mountain West: natural history, ecology, and conservation. University Press of Colorado, Boulder.

Armstrong, D.M. 1972. Distribution of mammals in Colorado. Monogr., Univ. Kansas Mus. Natu Hist. 3:1415.

Beason, R.C. 1995. Horned Lark (Eremophila alpestris), The Birds of North America (P.G. Rodewald, ed.). Ithaca: Cornell Lab of Ornithology. Retrieved from the Birds of North America: https://birdsna.org/Species-Account/bna/species/horlar.

Cilimburg, A. 2007. Flammulated Owl Protocol. Northern Region Landbird Monitoring Program, Flammulated Owl Protocol. Avian Science Center, Division of Biological Sciences, University of Montana, Missoula, MT. 12pp.

Colorado Natural Areas Program. 1998. Native Plant Revegetation Guide for Colorado. Denver, CO. 
Colorado Natural Heritage Program (CNHP). 2016. Results of database query for rare and/or imperiled species and natural communities known from or likely to occur within a two-mile radius of the NWTC. June.

Colorado Parks and Wildlife (CPW). 2016. List of federal and state threatened and endangered species in Colorado. Available at: http://cpw.state.co.us/learn/Pages/SOC-ThreatenedEndangeredList.aspx. Last accessed: October 13, 2016.

Cowardin, L.M., V. Carter, F.C. Golet, and E.T. LaRoe. 1979. Classification of Wetlands and Deepwater Habitats of the U.S. Library of Congress, Washington, DC.

Droege, S. 2010. Amphibian Calling Surveys. USGS Patuxent Wildlife Research Center, Laurel, MD. Available at: http://www.pwrc.usgs.gov/monmanual/techniques/amphibcallingsurveys.htm. Last accessed: March 2010.

Elphick, C., J.B. Dunning, Jr., and D.A. Sibley. 2001. National Audubon Society Guide to Bird Life \& Behavior. Alfred A. Knopf, New York.

Erickson W.P., J. Jeffrey, K. Kronner, and K. Bay. 2004. Stateline Wind Project wildlife monitoring final report July 2001-December 2003. Western EcoSystems Technology, Cheyenne, WY and Northwest Wildlife Consultants, Pendleton, OR.

Gascon, C., T.P. Collins, R.D. Moore, D.R. Church, J.E. McKay, and J.R. Mendelson III (eds.). 2005. Amphibian Conservation Action Plan. Proceedings: IUNC/SSC Amphibian Conservation Summit 2005. Largo, MD.

Hanni, D.J., C.M. White, J.A. Blakesley, G.J. Levandoski, and J.J. Birek. 2009. Point Transect Protocol. Unpublished report. Rocky Mountain Bird Observatory, Brighton, CO. 37 pp.

Hutchison, K. 1970. A test for comparing diversity based on the Shannon formula. J. of Theoretical Biology 29:151-154.

Johnson G.D., W.P. Erickson, M.D. Strickland, M.F. Shepherd, and D.A. Shepherd. 2000. Avian monitoring studies at the Buffalo Ridge Wind Resource Area, Minnesota: results of a four-year study. Technical report prepared for Northern States Power Co., Minneapolis, MN. Western EcoSystems Technology, Inc., Cheyenne, WY.

Jackson, B.J. and J.A. Jackson. 2000. Killdeer (Charadrius vociferus), The Birds of North America (P.G. Rodewald, ed.). Ithaca: Cornell Lab of Ornithology; Retrieved from the Birds of North America: https://birdsna.org/Species-Account/bna/species/killde.

Monahan, M.W. 1996. Raptor presence in and around the National Wind Technology Center: An assessment of risks and management alternatives. National Renewable Energy Laboratory, Golden, CO.

North American Bird Conservation Initiative, U.S. Committee (NABC). 2014. The State of the Birds 2014 Report. U.S. Department of the Interior, Washington, DC. 16 pages.

Peet, R.K. 1975. Relative Diversity Indices. Ecology 56(2):496-498.

Plantae Consulting Services. 2000. Vegetation Survey Report. National Renewable Energy Laboratory National Wind Technology Center. September 30.

Ryon, T. 2016. Email from Tom Ryon, Senior Environmental Scientist, NREL to Karen Baud, Wildlife Biologist at ERO Resources Corporation. May 26. 
Sauer, J.R., J.E. Hines, J.E. Fallon, K.L. Pardieck, D.J. Ziolkowski, Jr., and W.A. Link. 2014. The North American Breeding Bird Survey, Results and Analysis 1966 - 2013. Version 01.30.2015 USGS Patuxent Wildlife Research Center, Laurel, MD.

Schmidt, E., A.J. Piaggio, C.E. Bock, and D.M. Armstrong. 2003. National Wind Technology Center Site Environmental Assessment: Bird and Bat Use and Fatalities-Final Report. NREL/SR-500-32981.

Sikes. R.S. and the Animal Care and Use Committee of the American Society of Mammalogists. 2016. Journal of Mammalogy 97(3):663-688.

Shaffer, J.A. and D.A. Buhl. 2015. Effects of wind-energy facilities on breeding grassland bird distributions. Conservation Biology 30; 59-71.

Smallwood, J.A. and D.M. Bird. 2002. American Kestrel (Falco sparverius), The Birds of North America (P. G. Rodewald, ed.). Ithaca: Cornell Lab of Ornithology; Retrieved from the Birds of North America: https://birdsna.org/Species-Account/bna/species/amekes.

Tetra Tech EC, Inc. (Tetra Tech). 2011. Avian Monitoring and Mortality Report. National Wind Technology Center. Prepared for National Renewable Energy Laboratory. 81 pp.

U.S. Department of Agriculture (USDA), Natural Resource Conservation Service (NRCS). 2016. The PLANTS Database. Available at: http://plants.usda.gov. National Plant Data Team, Greensboro, NC 27401-4901 USA. September 26.

U.S. Fish and Wildlife Service (USFWS). 2015. Listed species believed to or known to occur in Colorado. Environmental Conservation Online System. Available at: http://ecos.fws.gov/ecp0/reports/specieslisted-by-state-report?state=CO\&status=listed.

U.S. Fish and Wildlife Service (USFWS). 2009. Endangered and threatened wildlife and plants; 90-day finding on a petition to list the northern leopard frog (Lithobates [=Rana] pipiens) in the western United States as Threatened. Federal Register 63:31389-31401.

U.S. Geological Survey (USGS) Patuxent Wildlife Research Center. 2014. North American Breeding Bird Survey 1966-2014 Analysis.

Walsh Environmental Scientists and Engineers (Walsh). 2011a. 2010-2011 Vegetation and Wildlife Surveys at the National Renewable Energy Laboratory National Wind Technology Center, Jefferson County, CO. Prepared for the National Renewable Energy Laboratory. Golden, CO. 127 pp.

Walsh Environmental Scientists and Engineers (Walsh). 2011b. Bat Acoustical Surveys at the National Renewable Energy Laboratory, National Wind Technology Center, Jefferson County, CO. Prepared for the National Renewable Energy Laboratory. Golden, CO. 81 pp. 
2016 Wildlife and Vegetation Monitoring Report

National Wind Technology Center

Jefferson County, Colorado

Appendix A Vegetation Inventory Data Forms

ERO Resources Corporation

This report is available at no cost from the National Renewable Energy Laboratory (NREL) at www.nrel.gov/publications 
DATA FORM - Vegetation Inventory

Site 1

Project/Site: $\quad$ NWTC

Investigator: $\quad$ Tony Romano

Date: $8 / 9 / 2016$

County/State_ CO

\begin{tabular}{|c|c|}
\hline Dom. Plant Species & Rel. \% \\
\hline 1 Poa pratensis & 15 \\
\hline 2 Bromus inermis & 15 \\
\hline 3 Juncus arcticus & 10 \\
\hline 4 Eleocharis palustris & 10 \\
\hline 5 Carex nebrascensis & 7 \\
\hline 6 Scirpus pallidus & 7 \\
\hline 7 Typha latifolia & 6 \\
\hline 8 Andropogon gerardii & 5 \\
\hline 9 Pascopyrum smithii & 5 \\
\hline 10 Hordeum jubatum & 3 \\
\hline 11 Oenothera elata & 3 \\
\hline 12 Verbascum thapsus & 2 \\
\hline
\end{tabular}

\begin{tabular}{|l|l|}
\hline Dom. Plant Species & Rel. $\%$ \\
\hline 13 Polypogon monspeliensis & 2 \\
\hline 14 Echinochloa crus-galli & 2 \\
\hline 15 Juncus torreyi & 2 \\
\hline 16 Cirsium arvense & 2 \\
\hline 17 Asclepias incarnata & 1 \\
\hline 18 Epilobium sp. & 1 \\
\hline 19 Juncus ensifolius & 1 \\
\hline 20 Juncus sp. & 1 \\
\hline 21 & \\
\hline 22 & \\
\hline 23 & \\
\hline 24 & \\
\hline
\end{tabular}

Remarks: Wetland/mesic prairie complex. Areas of inundation adjacent to upland mesic grasslands.

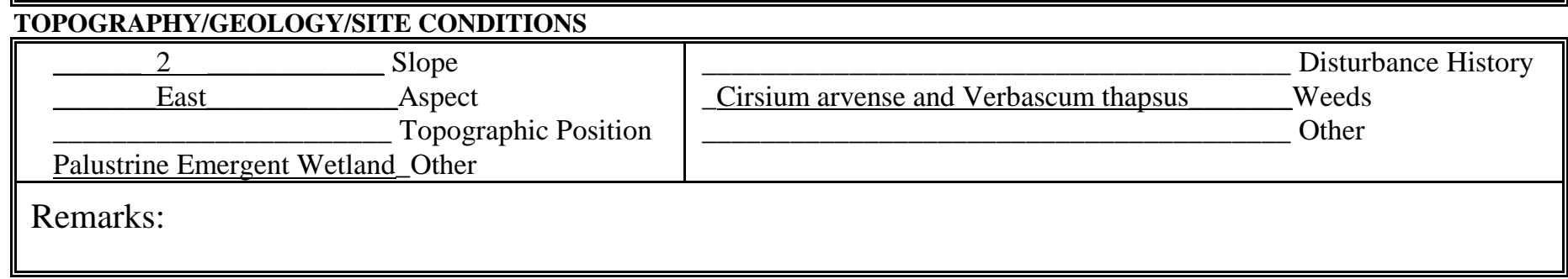

SOILS

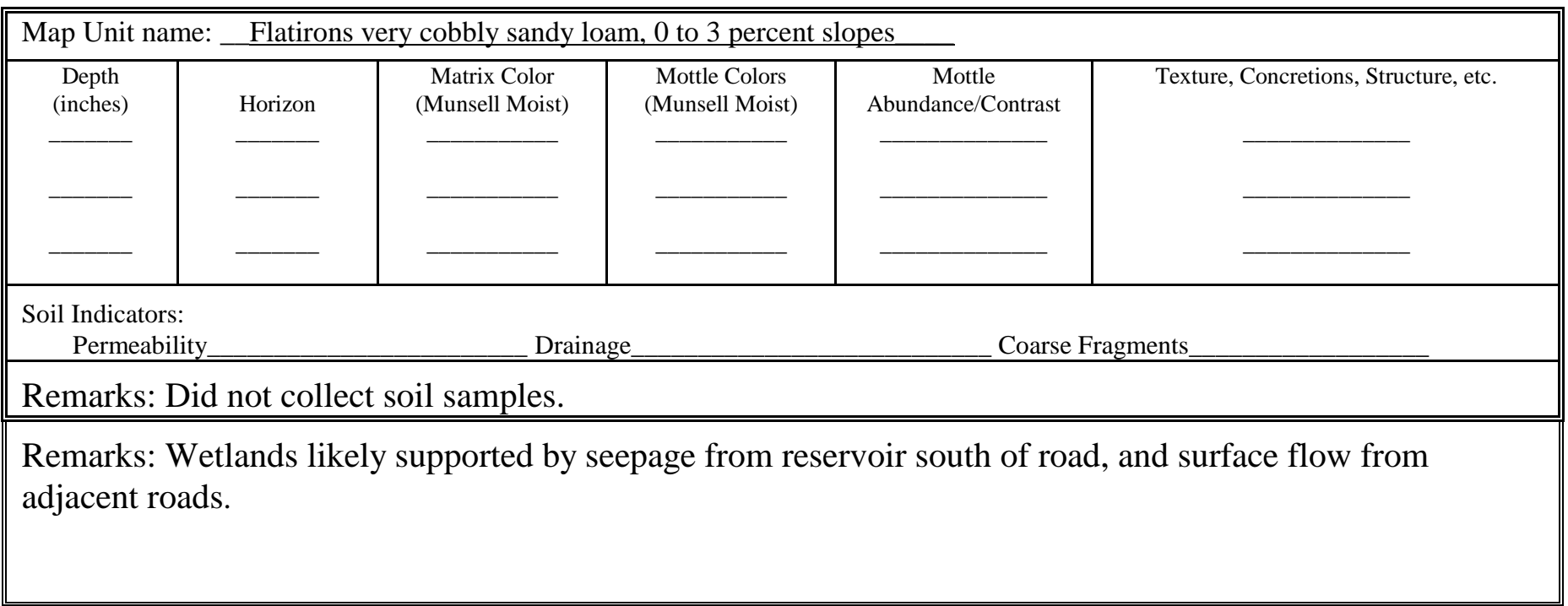


DATA FORM - Vegetation Inventory

Site 2

\begin{tabular}{|ll|l||}
\hline $\begin{array}{l}\text { Project/Site: } \\
\text { Investigator: }\end{array}$ & NWTC & $\begin{array}{l}\text { Date: 8/9/2016 } \\
\text { County/State_CO Romano }\end{array}$ \\
\hline \hline
\end{tabular}

\begin{tabular}{|c|c|c|c|}
\hline \multicolumn{4}{|l|}{ VEGETATION } \\
\hline Dom. Plant Species & Rel. \% & Dom. Plant Species & Rel. \% \\
\hline 1 Bromus tectorum & 40 & 13 Heterotheca villosa & 1 \\
\hline 2 Yucca glauca & 15 & 14 Helianthus pumilus & 1 \\
\hline 3 Poa compressa & 10 & 15 Artemisia frigida & 1 \\
\hline 4 Bromus inermis & 10 & 16 Eriogonum alatum & 1 \\
\hline 5 Poa pratensis & 5 & 17 Ambrosia psilostachya & 1 \\
\hline 6 Andropogon gerardii & 3 & 18 & \\
\hline 7 Koeleria macrantha & 2 & 19 & \\
\hline 8 Verbascum thapsus & 2 & 20 & \\
\hline 9 Artemisia ludoviciana & 2 & 21 & \\
\hline 10 Centaurea diffusa & 2 & 22 & \\
\hline 11 Psoralidium tenuiflorum & 2 & 23 & \\
\hline 12 Thinopyrum intermedium & 2 & 24 & \\
\hline \multicolumn{4}{|c|}{$\begin{array}{l}\text { Remarks: Xeric grassland, distinguished by presence of Yucca which is largely absent from surrounding } \\
\text { prairie. }\end{array}$} \\
\hline \multicolumn{4}{|l|}{ TOPOGRAPHY/GEOLOGY/SITE CONDITIONS } \\
\hline $\begin{array}{ll} & \text { Slope } \\
& \text { Aspect } \\
\text { Topographic Position } \\
\text { Other }\end{array}$ & \multicolumn{3}{|c|}{$\begin{array}{cl} & \text { Disturbance History } \\
\text { C. arvense, A. diffusa, V. thapsus } & \text { Weeds } \\
\text { Non-native Yucca Grassland } & \text { Community Type }\end{array}$} \\
\hline
\end{tabular}

SOILS

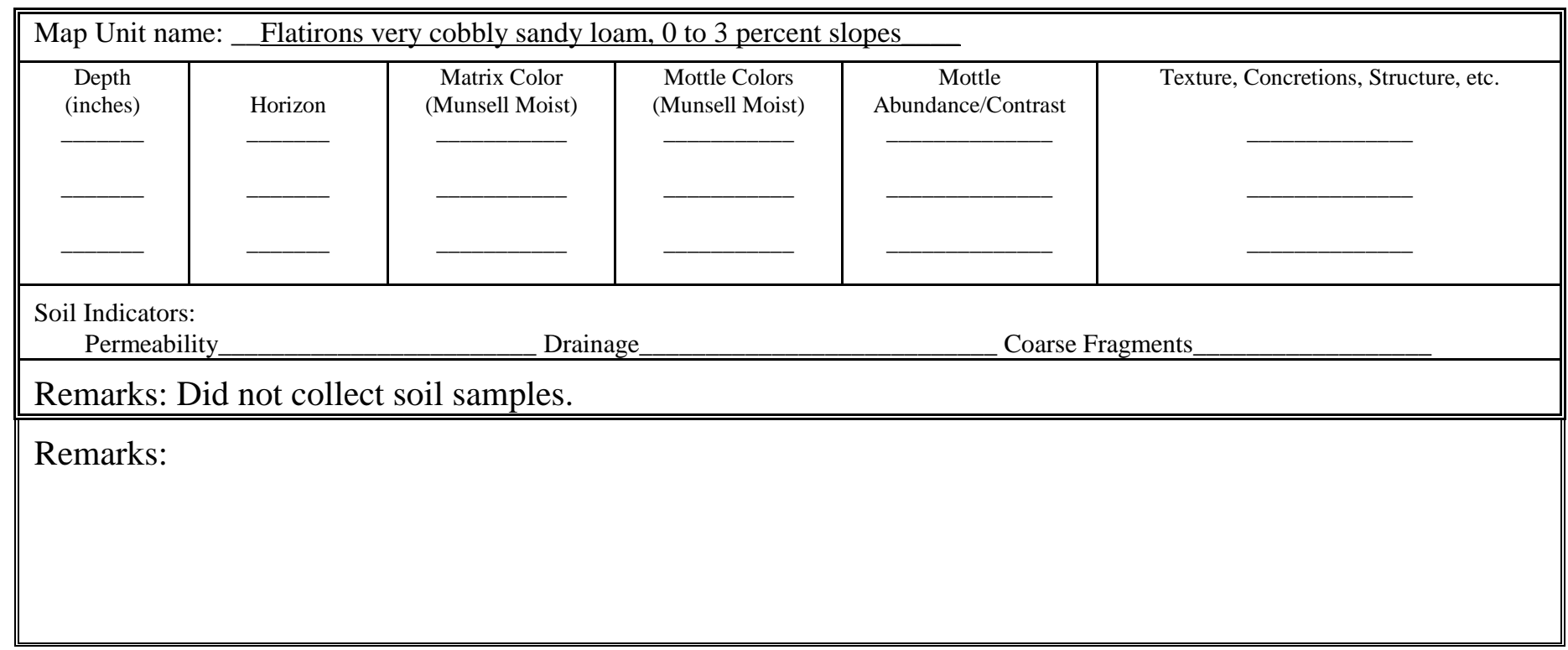


DATA FORM - Vegetation Inventory

Site 3

\begin{tabular}{||l|l|l||}
\hline $\begin{array}{l}\text { Project/Site: } \\
\text { Investigator: }\end{array}$ & NWTC & $\begin{array}{l}\text { Date: 8/9/2016 } \\
\text { County/State_CO Romano }\end{array}$ \\
\hline \hline
\end{tabular}

\begin{tabular}{|c|c|c|c|}
\hline \multicolumn{4}{|l|}{ VEGETATION } \\
\hline Dom. Plant Species & Rel. \% & Dom. Plant Species & Rel. \% \\
\hline 1 Bromus tectorum & 35 & 13 Heterotheca villosa & 1 \\
\hline 2 Thinopyrum intermedium & 25 & 14 Ambrosia psilostachya & 1 \\
\hline 3 Bromus inermis & 12 & 15 Artemisia frigida & 1 \\
\hline 4 Poa pratensis & 9 & 16 & \\
\hline 5 Poa compressa & 5 & 17 & \\
\hline 6 Alyssum simplex & 3 & 18 & \\
\hline 7 Yucca glauca & 2 & 19 & \\
\hline 8 Verbascum thapsus & 2 & 20 & \\
\hline 9 Artemisia ludoviciana & 1 & 21 & \\
\hline 10 Apocynum cannabinum & 1 & 22 & \\
\hline 11 Psoralidium tenuiflorum & 1 & 23 & \\
\hline 12 Hypericum perforatum & 1 & 24 & \\
\hline \multicolumn{4}{|c|}{ Remarks: Disturbed grassland dominated by Bromus tectorum and Thinopyrum intermedium. } \\
\hline \multicolumn{4}{|l|}{ TOPOGRAPHY/GEOLOGY/SITE CONDITIONS } \\
\hline $\begin{array}{ll} & \text { Slope } \\
& \text { Aspect } \\
\text { Topographic Position } & \text { Other } \\
\end{array}$ & $-\frac{\text { Cirs }}{I}$ & $\begin{array}{ll}\text { arvense, } \quad \text { V. thapsus } \\
\text { arbed Grassland }\end{array}$ & $\begin{array}{l}\text { Disturbance History } \\
\text {-Weeds } \\
\text { _ Community Type }\end{array}$ \\
\hline \multicolumn{4}{|l|}{ Remarks: } \\
\hline
\end{tabular}

SOILS

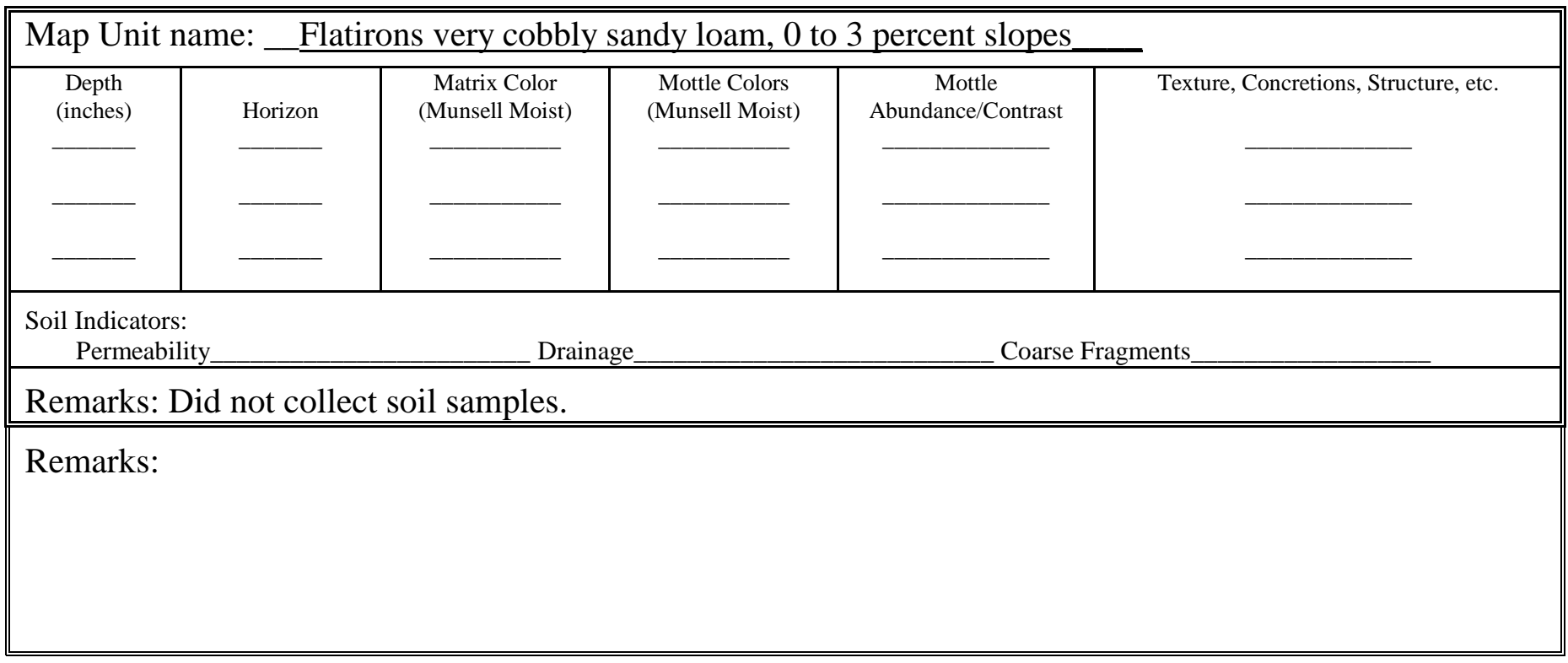


DATA FORM - Vegetation Inventory

Site 4

\begin{tabular}{|ll|l||}
\hline $\begin{array}{l}\text { Project/Site: } \\
\text { Investigator: }\end{array}$ & NWTC & $\begin{array}{l}\text { Date: 8/9/2016 } \\
\text { County/State_CO Romano }\end{array}$ \\
\hline \hline
\end{tabular}

VEGETATION
\begin{tabular}{|l|l||}
\hline Dom. Plant Species & Rel. \% \\
\hline 1 Thinopyrum intermedium & 30 \\
\hline 2 Helianthus annuus & 20 \\
\hline 3 Bassia scoparia & 20 \\
\hline 4 Bromus tectorum & 15 \\
\hline 5 Bromus inermis & 5 \\
\hline 6 Elymus canadensis & 3 \\
\hline 7 Mentzelia nuda & 2 \\
\hline 8 Elymus lanceolatus & 2 \\
\hline 9 Centaurea diffusa & 2 \\
\hline 10 Oenothera elata & 1 \\
\hline 11 & \\
\hline 12 & \\
\hline Remarks: Highly disturbed area with sign
\end{tabular}

\begin{tabular}{|l|l||}
\hline Dom. Plant Species & Rel. \% \\
\hline 13 & \\
\hline 14 & \\
\hline 16 & \\
\hline 17 & \\
\hline 18 & \\
\hline 19 & \\
\hline 20 & \\
\hline 21 & \\
\hline 22 & \\
\hline 23 & \\
\hline 24 & \\
\hline
\end{tabular}

Remarks: Highly disturbed area with significant bare ground. Dominated by annual/biennial weed species.

TOPOGRAPHY/GEOLOGY/SITE CONDITIONS

\begin{tabular}{||l|ll||}
\hline $\begin{array}{l}\text { Slope } \\
\text { Aspect } \\
\text { Topographic Position } \\
\text { Other }\end{array}$ & $\begin{array}{l}\text { Disturbance History } \\
\text { Westa diffusa, Bromus tectorum }\end{array}$ \\
\hline Remarks: & \\
\hline
\end{tabular}

\section{SOILS}

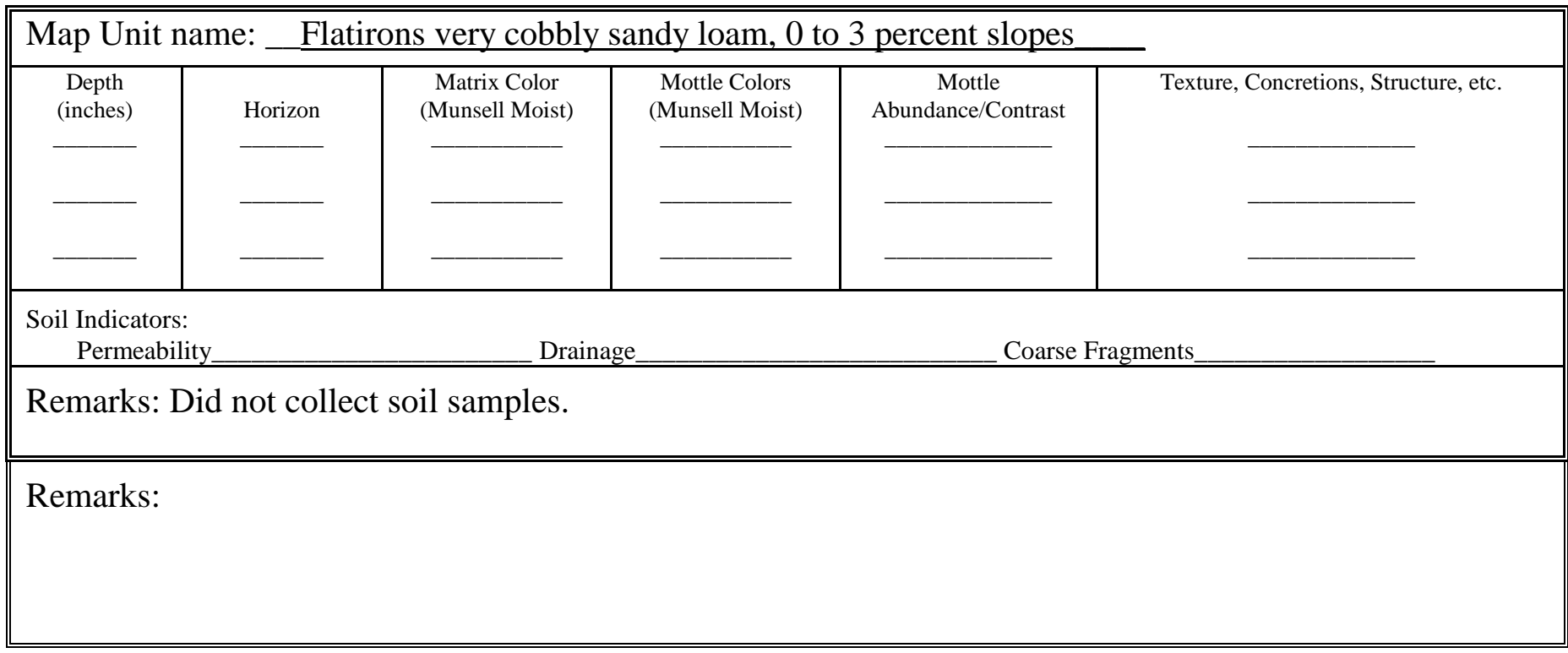


DATA FORM - Vegetation Inventory

Site 5

\begin{tabular}{|ll|l|}
\hline $\begin{array}{l}\text { Project/Site: } \\
\text { Investigator: }\end{array}$ & NWTC & $\begin{array}{l}\text { Date: 8/9/2016 } \\
\text { County/State_CO Romano }\end{array}$ \\
\hline
\end{tabular}

VEGETATION
\begin{tabular}{|l|l||}
\hline Dom. Plant Species & Rel. \% \\
\hline 1 Bromus inermis & 15 \\
\hline 2 Poa pratensis & 15 \\
\hline 3 Rhus trilobata & 15 \\
\hline 4 Prunus virginiana & 10 \\
\hline 5 Ribes cereum & 10 \\
\hline 6 Amelanchier alnifolia & 5 \\
\hline 7 Andropogon gerardii & 5 \\
\hline 8 Toxicodendron rydbergii & 5 \\
\hline 9 Poa compressa & 3 \\
\hline 10 Symphoricarpos occidentalis & 3 \\
\hline 11 Psoralidium tenuiflora & 1 \\
\hline 12 Hypericum perforatum & 1 \\
\hline Remarks: Mixed shrubland on rocky outcop. Underst
\end{tabular}

\begin{tabular}{|l|l||}
\hline Dom. Plant Species & Rel. \% \\
\hline 13 Rosa woodsii & 1 \\
\hline 14 Artemisia ludoviciana & 1 \\
\hline 15 Eriogonum umbellatum & 1 \\
\hline 16 Opuntia polyacantha & 1 \\
\hline 17 Heterotheca villosa & 1 \\
\hline 18 Solidago sp. & 1 \\
\hline 19 Prunus americana & 1 \\
\hline 20 Thermopsis rhombifolia & 1 \\
\hline 21 Bouteloua curtipendula & 1 \\
\hline 22 Bromus tectorum & 1 \\
\hline 23 Verbascum thapsus & 1 \\
\hline 24 Koeleria macrantha & 1 \\
\hline
\end{tabular}

Remarks: Mixed shrubland on rocky outcrop. Understory is Bromus inermis/poa pratensis dominated but native grasses and forbs have higher cover than in surrounding grasslands.

\begin{tabular}{|c|c|c|}
\hline TOPOGRAPHY/GEOLOGY/SITE CONDITIONS & & \\
\hline Slope & & Disturbance History \\
\hline Aspect & Multiple species & _Weeds \\
\hline _Topographic Position & Mixed Shrubland & Community Type \\
\hline Other & & \\
\hline
\end{tabular}

Remarks:

SOILS

\begin{tabular}{||c|c|c|c|c|c||}
\hline \hline \multicolumn{2}{||l}{ Map Unit name: _ Rock outcrop, sedimentary } \\
\hline $\begin{array}{c}\text { Depth } \\
\text { (inches) }\end{array}$ & Horizon & $\begin{array}{c}\text { Matrix Color } \\
\text { (Munsell Moist) }\end{array}$ & $\begin{array}{c}\text { Mottle Colors } \\
\text { (Munsell Moist) }\end{array}$ & $\begin{array}{c}\text { Mottle } \\
\text { Abundance/Contrast }\end{array}$ & Texture, Concretions, Structure, etc. \\
- & - & - & - & - & - \\
- & - & - & - & - & - \\
\hline
\end{tabular}

Soil Indicators:

Permeability

Drainage

Coarse Fragments

Remarks: Did not collect soil samples.

Remarks: 
DATA FORM - Vegetation Inventory

Site 6

\begin{tabular}{|ll|l|}
\hline $\begin{array}{l}\text { Project/Site: } \\
\text { Investigator: }\end{array}$ & NWTC & $\begin{array}{l}\text { Date: 8/9/2016 } \\
\text { County/State_CO Romano }\end{array}$ \\
\hline
\end{tabular}

\begin{tabular}{|c|c|}
\hline EGETATION & \\
\hline Dom. Plant Species & Rel. \% \\
\hline 1 Eleocharis palustris & 25 \\
\hline 2 Typha latifolia & 20 \\
\hline 3 Poa compressa & 10 \\
\hline 4 Poa pratensis & 10 \\
\hline 5 Bromus inermis & 8 \\
\hline 6 Juncus arcticus & 5 \\
\hline 7 Carex nebrascensis & 5 \\
\hline 8 Pascopyrum smithii & 3 \\
\hline 9 Hordeum jubatum & 3 \\
\hline 10 Polygonum punctatum & 3 \\
\hline 11 Andropogon gerardii & 2 \\
\hline 12 Verbascum thapsus & 2 \\
\hline
\end{tabular}

\begin{tabular}{|l|l||}
\hline Dom. Plant Species & Rel. $\%$ \\
\hline 13 Lactuca serriola & 1 \\
\hline 14 Cirsium arvense & 1 \\
\hline 16 Conyza canadensis & 1 \\
\hline 17 & 1 \\
\hline 18 & \\
\hline 19 & \\
\hline 20 & \\
\hline 22 & \\
\hline 23 & \\
\hline 24 & \\
\hline
\end{tabular}

Remarks: Wetlands within the shallow pond, mesic grasses and occasional weeds occur on slopes surrounding pond.

TOPOGRAPHY/GEOLOGY/SITE CONDITIONS

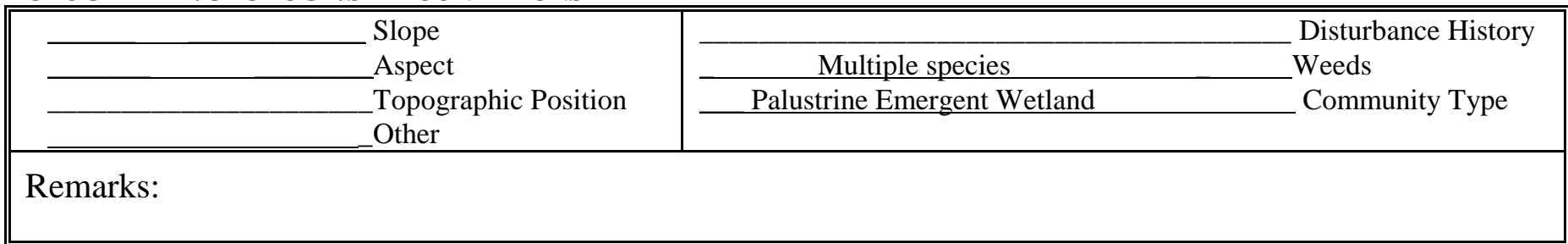

SOILS

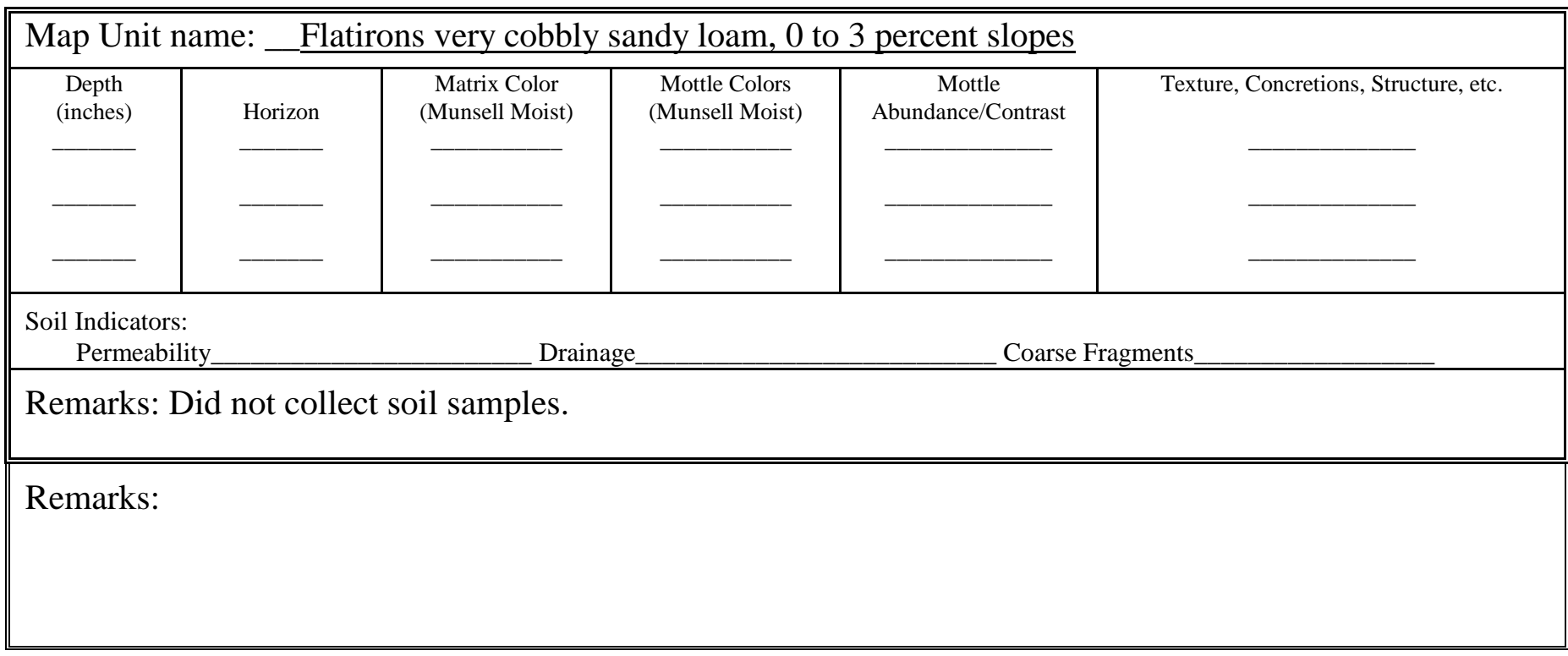


DATA FORM - Vegetation Inventory

Site 7

\begin{tabular}{ll}
\hline Project/Site: & NWTC \\
Investigator: & Tony Romano
\end{tabular}

Date: $8 / 9 / 2016$

County/State_ $\mathrm{CO}$

\begin{tabular}{|c|c|}
\hline Dom. Plant Species & Rel. \% \\
\hline 1 Pinus ponderosa & 20 \\
\hline 2 Rhus trilobata & 15 \\
\hline 3 Ribes cereum & 10 \\
\hline 4 Rosa woodsii & 7 \\
\hline 5 Prunus virginiana & 7 \\
\hline 6 Bromus inermis & 7 \\
\hline 7 Bromus tectorum & 5 \\
\hline 8 Symphoricarpos occidentalis & 5 \\
\hline 9 Koeleria macrantha & 5 \\
\hline 10 Agropyron cristatum & 3 \\
\hline 11 Andropogon gerardii & 2 \\
\hline 12 Verbascum thapsus & 2 \\
\hline
\end{tabular}

\begin{tabular}{|l|l||}
\hline Dom. Plant Species & Rel. \% \\
\hline 13 Poa pratensis & 1 \\
\hline 14 Centaurea diffusa & 1 \\
\hline 15 Potentilla recta & 1 \\
\hline 16 Thermopsis rhombifolia & 1 \\
\hline 17 Opuntia macrorhiza & 1 \\
\hline 18 Yucca glauca & 1 \\
\hline 19 Grindelia squarrosa & 1 \\
\hline 20 Heterotheca villosa & 1 \\
\hline 21 Liatris punctata & 1 \\
\hline 22 Cirsium arvense & 1 \\
\hline 23 Carduus nutans & 1 \\
\hline 24 Paronychia jamesii & 1 \\
\hline e/non-native understory. Highest concentration of
\end{tabular}

Remarks: Ponderosa pine woodland with mixed native/non-native understory. Highest concentration of Sulfur cinquefoil in the study area.

\section{TOPOGRAPHY/GEOLOGY/SITE CONDITIONS}

\begin{tabular}{||l|l||}
\hline \multicolumn{1}{|c|}{$\begin{array}{c}\text { Slope } \\
\text { Aspect } \\
\text { Topographic Position }\end{array}$} & Disturbance History \\
\hline Other & Weeds \\
\hline Remarks: & \\
\hline
\end{tabular}

SOILS

\begin{tabular}{|c|c|c|c|c|c|}
\hline \multicolumn{6}{|c|}{ Map Unit name: __ Rock outcrop, sedimentary } \\
\hline $\begin{array}{c}\begin{array}{c}\text { Depth } \\
\text { (inches) }\end{array} \\
\end{array}$ & Horizon & $\begin{array}{c}\text { Matrix Color } \\
\text { (Munsell Moist) }\end{array}$ & $\begin{array}{l}\text { Mottle Colors } \\
\text { (Munsell Moist) }\end{array}$ & $\begin{array}{c}\text { Mottle } \\
\text { Abundance/Contrast }\end{array}$ & Texture, Concretions, Structure, etc. \\
\hline $\begin{array}{r}\text { Soil Indicat } \\
\text { Perme }\end{array}$ & \multicolumn{3}{|c|}{ Drainage } & \multicolumn{2}{|c|}{ Coarse Fragments } \\
\hline \multicolumn{6}{|c|}{ Remarks: Did not collect soil samples. } \\
\hline \multicolumn{6}{|c|}{ Remarks: } \\
\hline
\end{tabular}


DATA FORM - Vegetation Inventory

Site 8

\begin{tabular}{|ll|l|}
\hline $\begin{array}{l}\text { Project/Site: } \\
\text { Investigator: }\end{array}$ & NWTC & $\begin{array}{l}\text { Date: 8/9/2016 } \\
\text { County/State_CO Romano }\end{array}$ \\
\hline
\end{tabular}

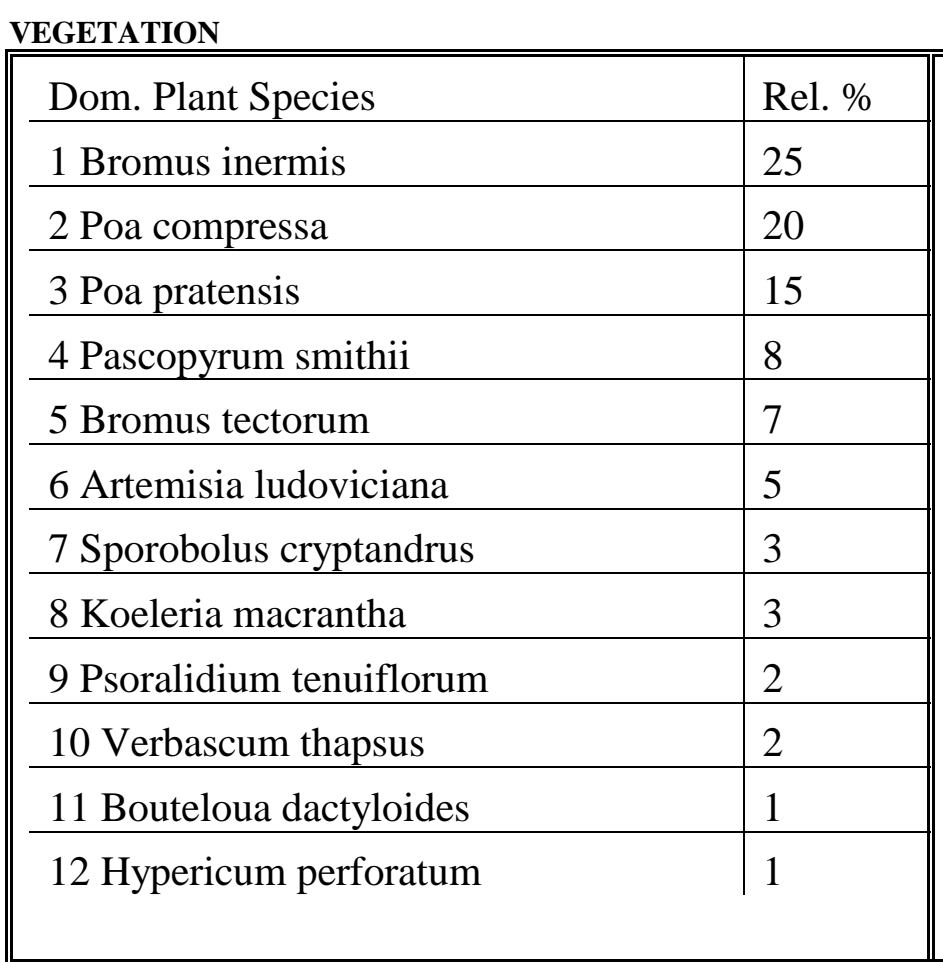

\begin{tabular}{|l|l||}
\hline Dom. Plant Species & Rel. \% \\
\hline 13 Yucca glauca & 1 \\
\hline 14 Cirsium arvense & 1 \\
\hline 15 Centaurea diffusa & 1 \\
\hline 16 Alyssum simplex & 1 \\
\hline 17 Convolvulus arvensis & 1 \\
\hline $\begin{array}{l}18 \text { Symphoricarpos } \\
\text { occidentalis }\end{array}$ & 1 \\
\hline 19 Thinopyrum intermedium & 1 \\
\hline 20 Onosmodium bejariense & 1 \\
\hline 21 & \\
\hline 22 & \\
\hline 23 & \\
\hline 24 & \\
\hline
\end{tabular}

Remarks: Non-native grassland dominated by smooth brome, Canada bluegrass, and Kentucky bluegrass.

\section{TOPOGRAPHY/GEOLOGY/SITE CONDITIONS}

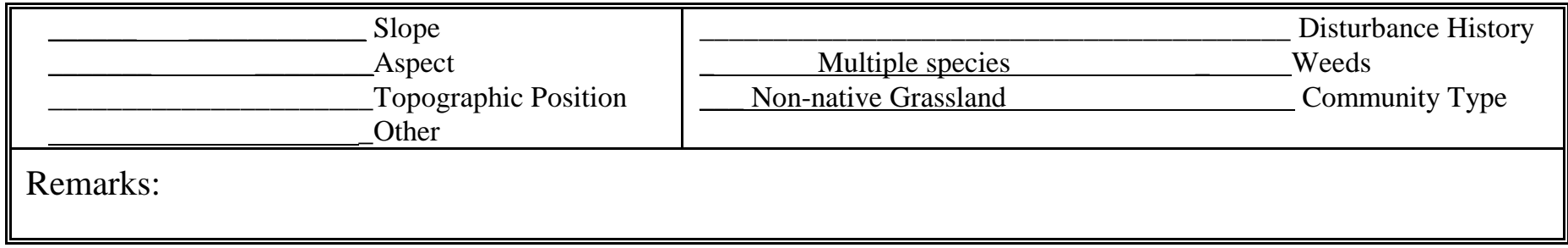

SOILS

Map Unit name: __ Flatirons very cobbly sandy loam, 0 to 3 percent slopes and Yoder variant-Midway complex, 15 to 60 percent slopes.

\begin{tabular}{|c|c|c|c|c|c}
\hline $\begin{array}{c}\text { Depth } \\
\text { (inches) }\end{array}$ & Horizon & $\begin{array}{c}\text { Matrix Color } \\
\text { (Munsell Moist) }\end{array}$ & $\begin{array}{c}\text { Mottle Colors } \\
\text { (Munsell Moist) }\end{array}$ & $\begin{array}{c}\text { Mottle } \\
\text { Abundance/Contrast }\end{array}$ & Texture, Concretions, Structure, etc. \\
- & - & - & - & - \\
- & - & - & - & - \\
\hline
\end{tabular}

Soil Indicators:

Permeability

Drainage

Coarse Fragments

Remarks: Did not collect soil samples.

Remarks: 


\begin{tabular}{||l|l||}
\hline \hline $\begin{array}{l}\text { Project/Site: } \\
\text { Investigator: }\end{array}$ & NWTC \\
\hline \hline
\end{tabular}

VEGETATION
\begin{tabular}{||l|l||}
\hline Dom. Plant Species & Rel. \% \\
\hline 1 Aristida purpurea & 30 \\
\hline 2 Andropogon gerardii & 20 \\
\hline 3 Panicum virgatum & 10 \\
\hline 4 Grindelia squarrosa & 10 \\
\hline 5 Helianthus annuus & 5 \\
\hline 6 Bouteloua gracilis & 5 \\
\hline 7 Centaurea diffusa & 3 \\
\hline 8 Ambrosia psilostachya & 3 \\
\hline 9 Bassia scoparia & 3 \\
\hline 10 Verbascum thapsus & 2 \\
\hline 11 Bromus tectorum & 1 \\
\hline 12 Bromus inermis & 1 \\
\hline Remis & \\
\hline
\end{tabular}

\begin{tabular}{||l|l||}
\hline Dom. Plant Species & Rel. \% \\
\hline 13 Juncus sp. & 1 \\
\hline 14 Verbascum blattaria & 1 \\
\hline 15 Heterotheca villosa & 1 \\
\hline 16 Lactuca serriola & 1 \\
\hline 17 Solanum rostratum & 1 \\
\hline 18 Verbena bracteata & 1 \\
\hline 19 Conyza canadensis & 1 \\
\hline 20 & \\
\hline 21 & \\
\hline 22 & \\
\hline 23 & $\mid$ \\
\hline 24 & \\
\hline
\end{tabular}

Remarks: Disturbed Native Grassland. High coverage of native plants, lots of bare ground, and scattered weed species.

\section{TOPOGRAPHY/GEOLOGY/SITE CONDITIONS}

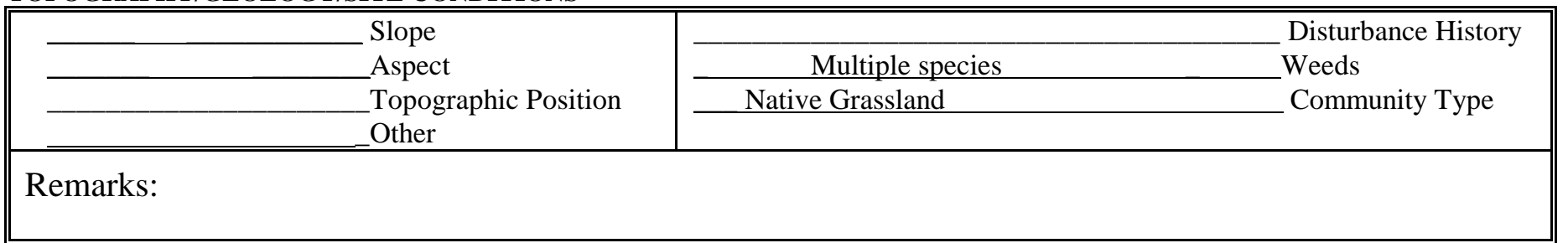

\section{SOILS}

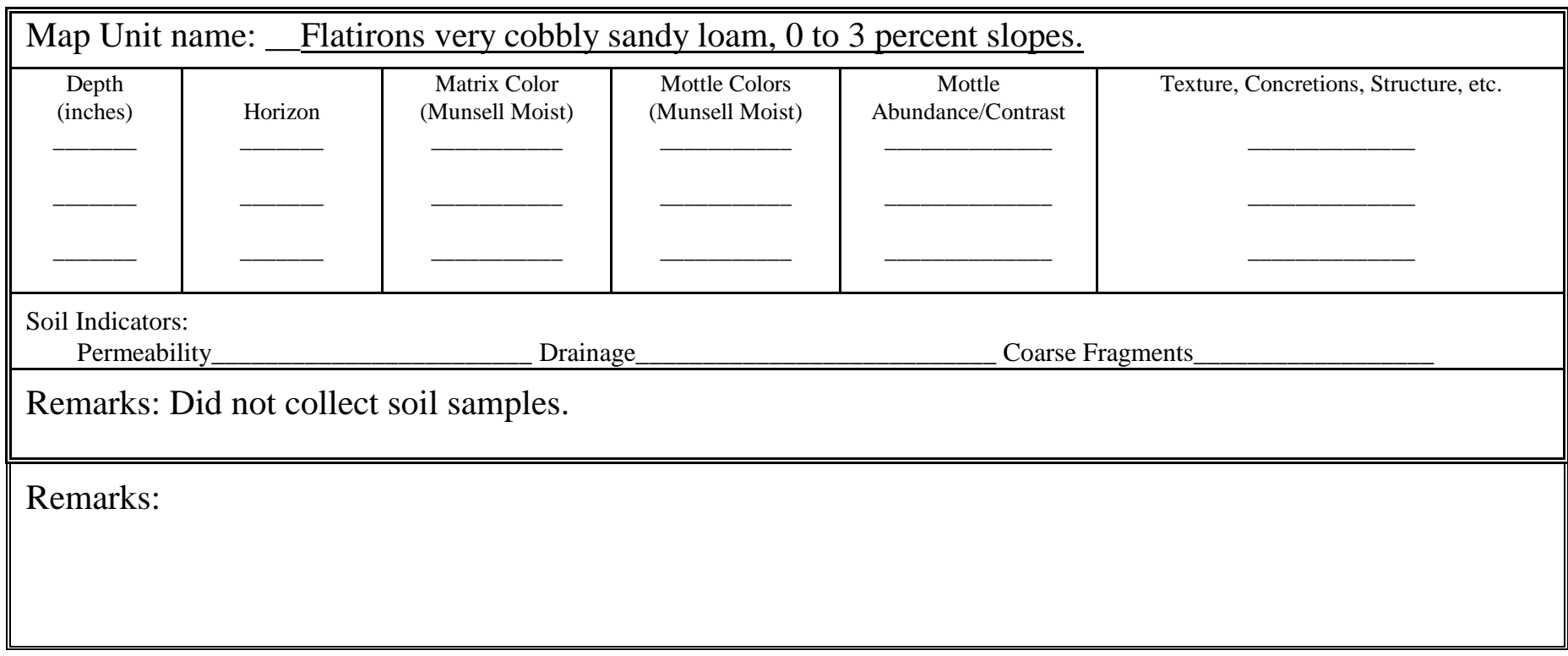


DATA FORM - Vegetation Inventory

\begin{tabular}{||l|l|l||}
\hline $\begin{array}{l}\text { Project/Site: } \\
\text { Investigator: }\end{array}$ & NWTC & $\begin{array}{l}\text { Date: 8/9/2016 } \\
\text { County/State_CO Romano }\end{array}$ \\
\hline \hline
\end{tabular}

VEGETATION
\begin{tabular}{||l|l||}
\hline Dom. Plant Species & Rel. \% \\
\hline 1 Juncus arcticus & 30 \\
\hline 2 Spartina pectinata & 20 \\
\hline 3 Typha angustifolia & 10 \\
\hline 4 Hordeum jubatum & 10 \\
\hline 5 Dipsacus fullonum & 5 \\
\hline 6 Bromus inermis & 5 \\
\hline 7 Asclepias speciosa & 3 \\
\hline 8 Cirsium arvense & 3 \\
\hline 9 Glycyrrhiza lepidota & 3 \\
\hline 10 Oenothera curtiflora & 2 \\
\hline 11 Epilobium sp. & 1 \\
\hline 12 Asclepias incarnata & 1 \\
\hline
\end{tabular}

\begin{tabular}{|l|l||}
\hline Dom. Plant Species & Rel. \% \\
\hline 13 Carex nebrascensis & 1 \\
\hline 14 Nepeta cataria & 1 \\
\hline 15 Populus deltoides & 1 \\
\hline 16 Salix exigua & 1 \\
\hline 17 Cirsium vulgare & 1 \\
\hline 18 Oenothera elata & 1 \\
\hline $\begin{array}{l}19 \text { Symphoricarpos } \\
\text { occidentalis }\end{array}$ & 1 \\
\hline 20 Verbascum thapsus & \\
\hline 21 Geum aleppicum & \\
\hline 22 Poa pratensis & \\
\hline 23 Panicum virgatum & \\
\hline 24 & \\
\hline
\end{tabular}

Remarks: Riparian emergent wetlands in a drainage near northern boundary of the site.

\section{TOPOGRAPHY/GEOLOGY/SITE CONDITIONS}

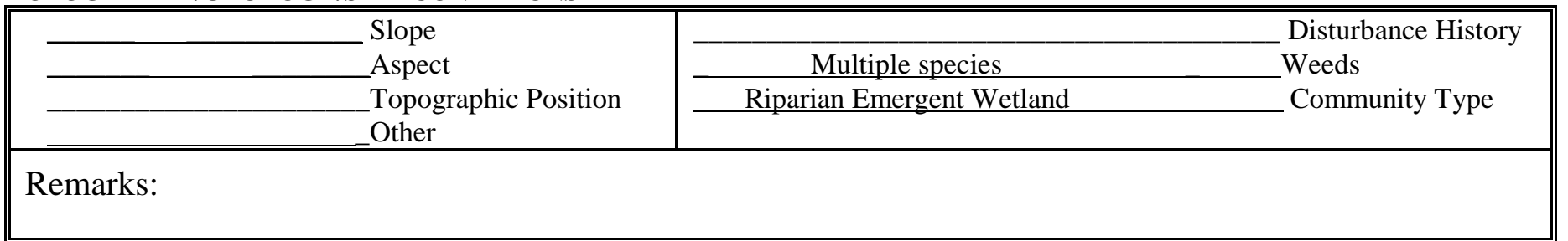

\section{SOILS}

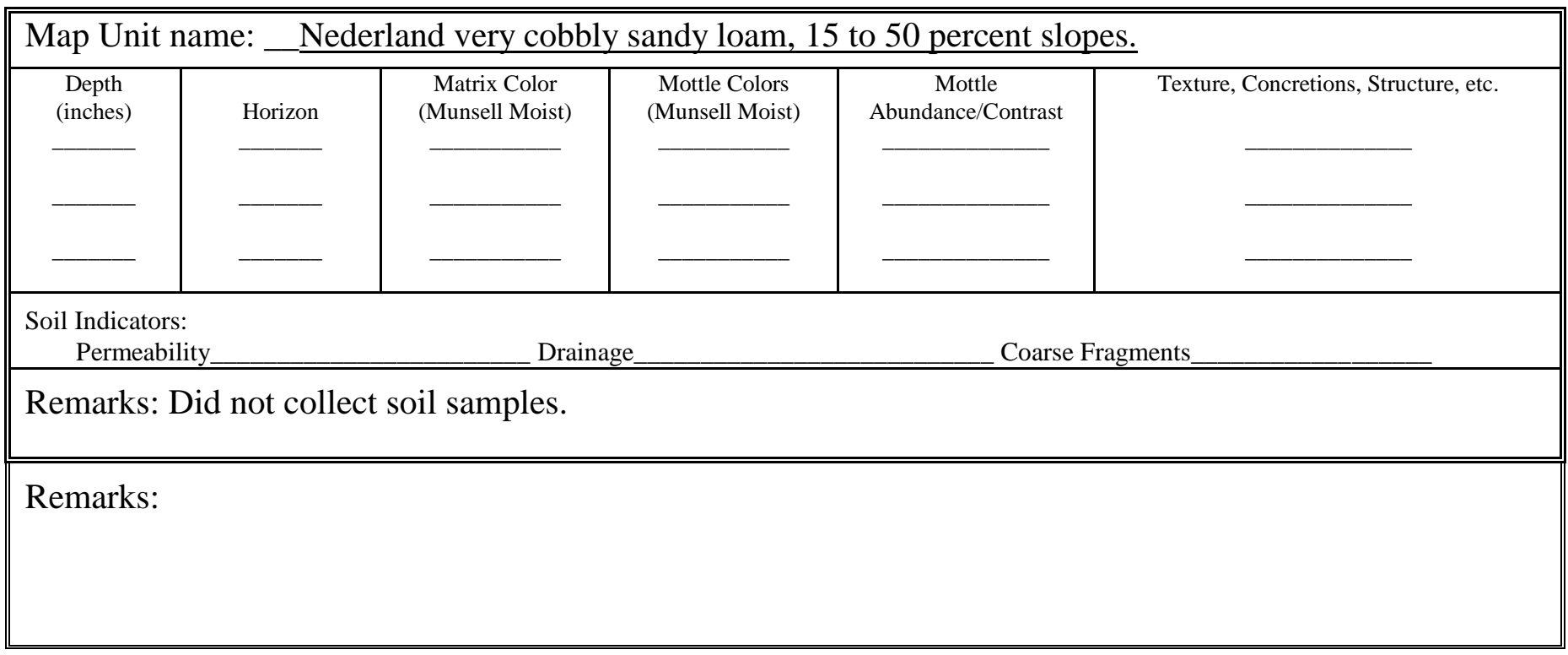


DATA FORM - Vegetation Inventory

\begin{tabular}{|ll|l|}
\hline $\begin{array}{l}\text { Project/Site: } \\
\text { Investigator: }\end{array}$ & Tony Romano & $\begin{array}{l}\text { Date: 8/9/2016 } \\
\text { County/State_CO }\end{array}$ \\
\hline
\end{tabular}

VEGETATION
\begin{tabular}{||l|l||}
\hline Dom. Plant Species & Rel. \% \\
\hline 1 Bromus inermis & 20 \\
\hline 2 Poa pratensis & 15 \\
\hline 3 Carex nebrascensis & 15 \\
\hline 4 Eleocharis palustris & 15 \\
\hline 5 Juncus arcticus & 5 \\
\hline 6 Carex brevior & 3 \\
\hline 7 Polygonum punctatum & 3 \\
\hline 8 Panicum virgatum & 3 \\
\hline 9 Pascopyrum smithii & 2 \\
\hline 10 Juncus ensifolius & 2 \\
\hline 11 Juncus longistylis & 2 \\
\hline 12 Thinopyrum intermedium & 2 \\
\hline
\end{tabular}

\begin{tabular}{|l|l|}
\hline Dom. Plant Species & Rel. \% \\
\hline 13 Agropyron cristatum & 2 \\
\hline 14 Nepeta cataria & 1 \\
\hline 15 Bromus tectorum & 1 \\
\hline 16 Oenothera elata & 1 \\
\hline 17 Cirsium arvense & 1 \\
\hline 18 Verbascum thapsus & 1 \\
\hline 19 Verbascum blattaria & 1 \\
\hline 20 Dactylis glomerata & 1 \\
\hline 21 Asclepias speciosa & 1 \\
\hline 22 Epilobium sp. & 1 \\
\hline 23 Glycyrrhiza lepidota & 1 \\
\hline 24 Typha latifolia & 1 \\
\hline
\end{tabular}

Remarks: Riparian emergent wetlands in a drainage. Mullein and Canada thistle occurs in large patches on the slopes down to the drainage.

\section{TOPOGRAPHY/GEOLOGY/SITE CONDITIONS}

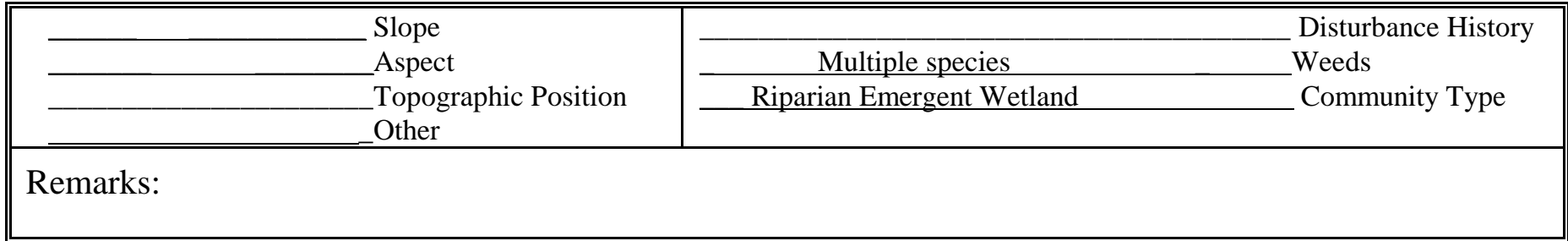

SOILS

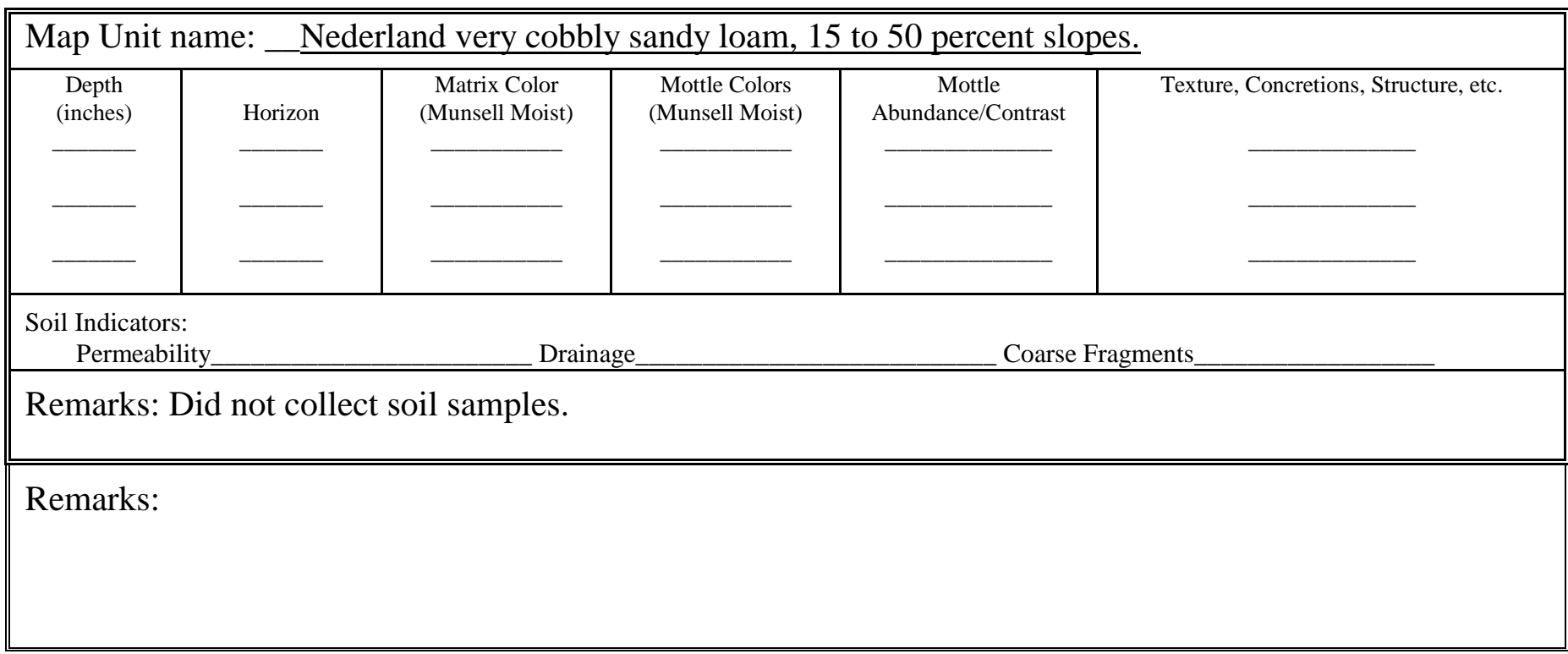




\begin{tabular}{|ll|l||}
\hline $\begin{array}{l}\text { Project/Site: } \\
\text { Investigator: }\end{array}$ & NWTC & $\begin{array}{l}\text { Date: 8/9/2016 } \\
\text { County/State_CO Romano }\end{array}$ \\
\hline \hline
\end{tabular}

\begin{tabular}{|c|c|}
\hline EGETATION & \\
\hline Dom. Plant Species & Rel. \% \\
\hline 1 Bromus inermis & 35 \\
\hline 2 Poa pratensis & 20 \\
\hline 3 Poa compressa & 7 \\
\hline 4 Andropogon gerardii & 5 \\
\hline 5 Koeleria macrantha & 5 \\
\hline 6 Verbascum thapsus & 5 \\
\hline 7 Bromus tectorum & 3 \\
\hline 8 Panicum virgatum & 3 \\
\hline 9 Thinopyrum intermedium & 2 \\
\hline 10 Yucca glauca & 2 \\
\hline 11 Alyssum simplex & 2 \\
\hline 12 Opuntia macrorhiza & 1 \\
\hline
\end{tabular}

\begin{tabular}{|l|l||}
\hline Dom. Plant Species & Rel. \% \\
\hline 13 Psoralidium tenuiflorum & 1 \\
\hline 14 Elymus elymoides & 1 \\
\hline 15 Verbascum blattaria & 1 \\
\hline 16 Artemisia ludoviciana & 1 \\
\hline 17 Ribes trilobatum & 1 \\
\hline 18 Lactuca serriola & 1 \\
\hline 19 Helianthus annuus & 1 \\
\hline 20 Conyza canadensis & 1 \\
\hline 21 Symphoricarpos & 1 \\
occidentalis & 1 \\
\hline 22 Juncus sp. & \\
\hline 23 & \\
\hline 24 & 1 \\
\hline
\end{tabular}

Remarks: Typical non-native/mixed prairie. Smooth brome dominated with scattered patches of native vegetation.

\begin{tabular}{l} 
TOPOGRAPHY/GEOLOGY/SITE CONDITIONS \\
\begin{tabular}{|l}
\hline Slope \\
Aspect \\
Topographic Position \\
Other
\end{tabular} \\
\hline
\end{tabular}

\begin{tabular}{rr}
\hline & Disturbance History \\
\hline Multiple species & Weeds \\
Non-Native Grassland & Community Type \\
\hline
\end{tabular}

Remarks:

\section{SOILS}

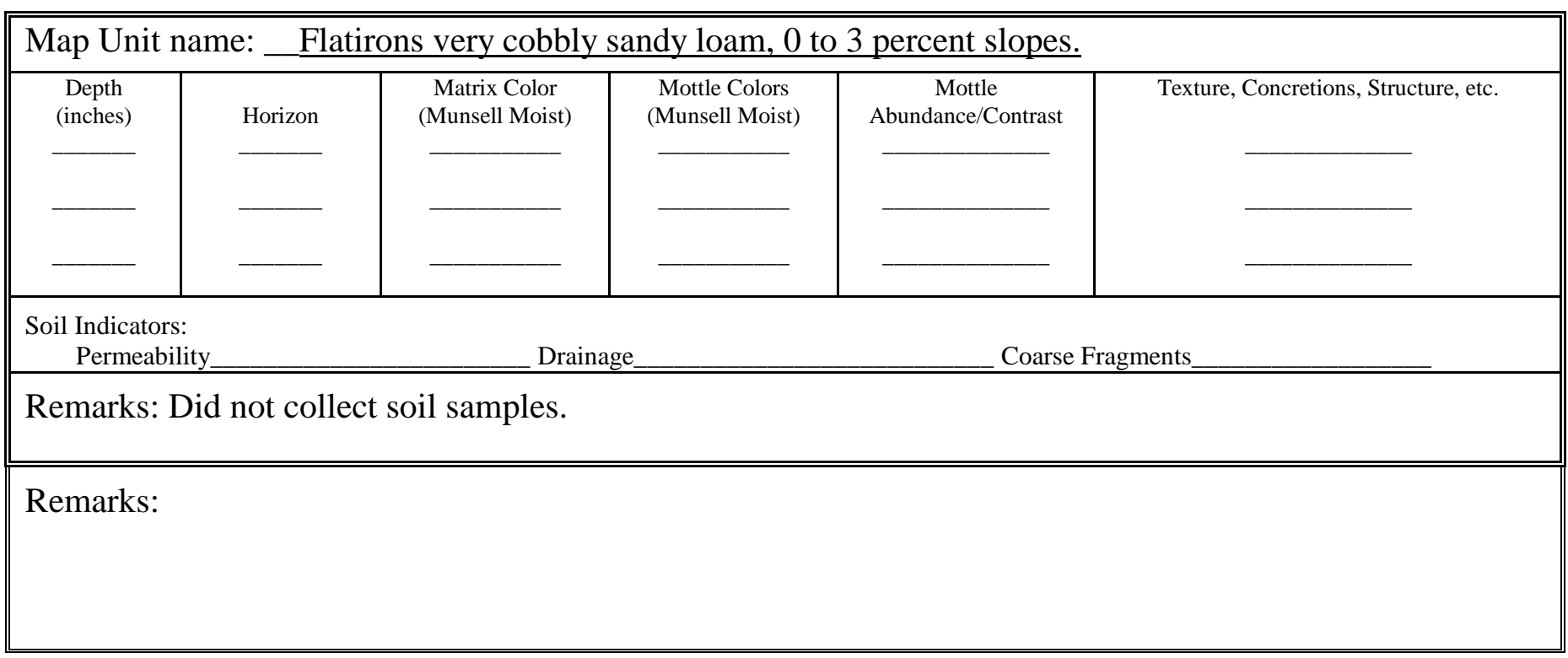


DATA FORM - Vegetation Inventory

\begin{tabular}{|ll|l||}
\hline $\begin{array}{l}\text { Project/Site: } \\
\text { Investigator: }\end{array}$ & NWTC & $\begin{array}{l}\text { Date: 8/9/2016 } \\
\text { County/State_CO Romano }\end{array}$ \\
\hline \hline
\end{tabular}

VEGETATION
\begin{tabular}{|l|l||}
\hline Dom. Plant Species & Rel. \% \\
\hline 1 Typha latifolia & 40 \\
\hline 2 Salix exigua & 20 \\
\hline 3 Populus deltoides & 15 \\
\hline 4 Hordeum jubatum & 10 \\
\hline 5 Bromus inermis & 5 \\
\hline 6 Poa pratensis & 5 \\
\hline 7 Cirsium arvense & 5 \\
\hline 8 & \\
\hline 9 & \\
\hline 10 & \\
\hline 11 & \\
\hline 12 & \\
\hline R & \\
\hline
\end{tabular}

\begin{tabular}{|l|l||}
\hline Dom. Plant Species & Rel. \% \\
\hline 13 & \\
\hline 14 & \\
\hline 16 & \\
\hline 17 & \\
\hline 18 & \\
\hline 19 & \\
\hline 20 & \\
\hline 21 & \\
\hline 22 & \\
\hline 23 & \\
\hline 24 & \\
\hline
\end{tabular}

Remarks: Scrub-Shrub/cattail wetland near southern boundary of the study area.

\section{TOPOGRAPHY/GEOLOGY/SITE CONDITIONS}

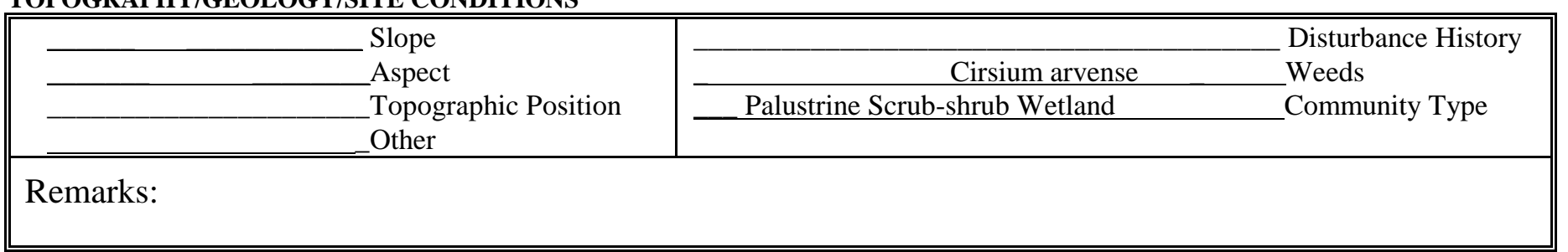

\section{SOILS}

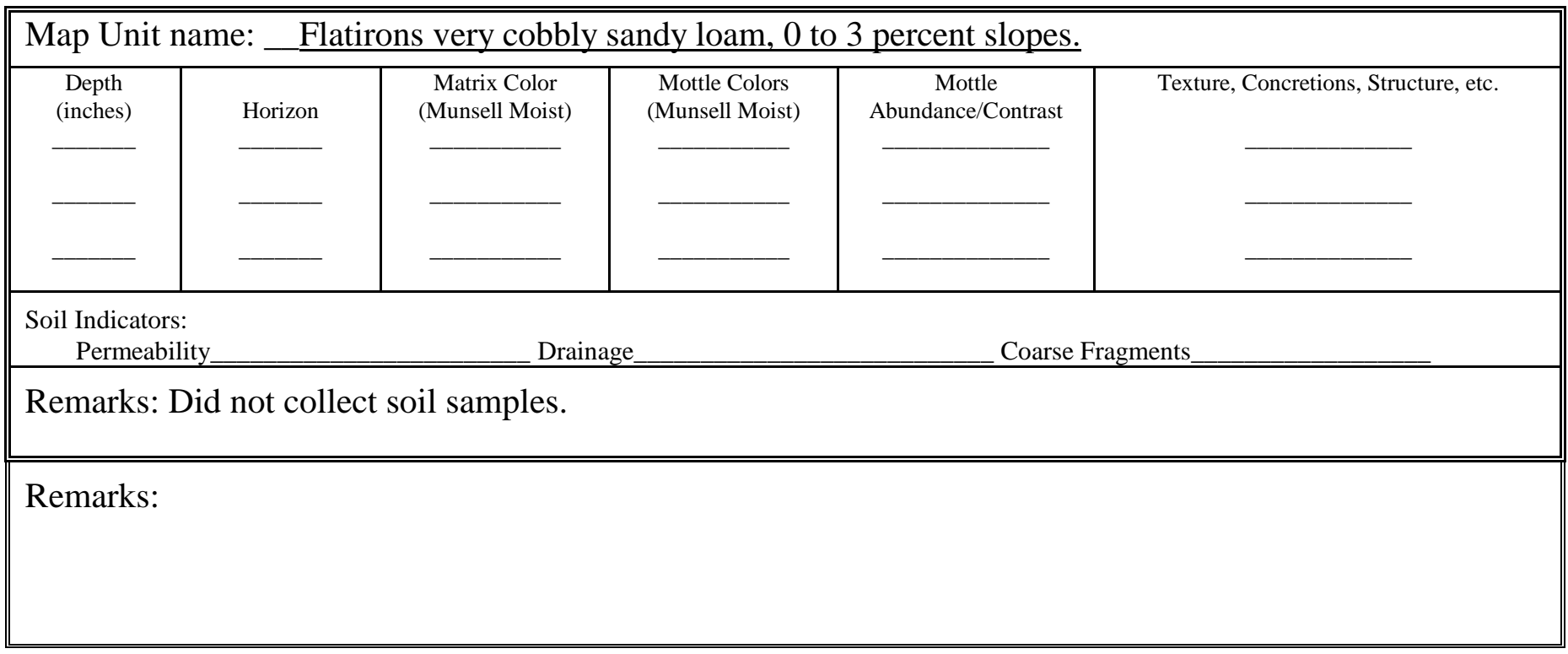


DATA FORM - Vegetation Inventory

\begin{tabular}{|ll|l||}
\hline $\begin{array}{l}\text { Project/Site: } \\
\text { Investigator: }\end{array}$ & NWTC & $\begin{array}{l}\text { Date: 8/9/2016 } \\
\text { County/State_CO Romano }\end{array}$ \\
\hline \hline
\end{tabular}

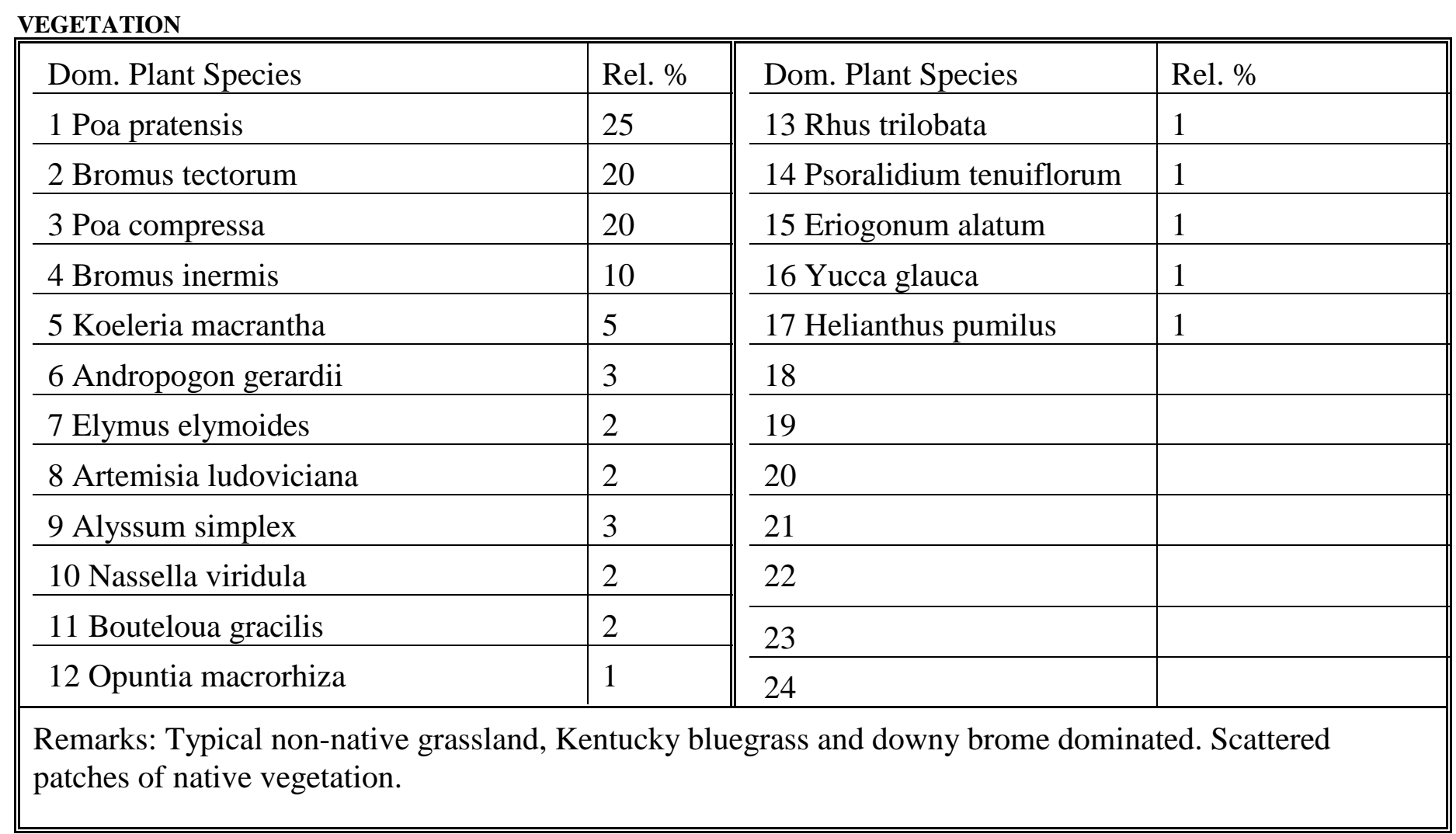

TOPOGRAPHY/GEOLOGY/SITE CONDITIONS

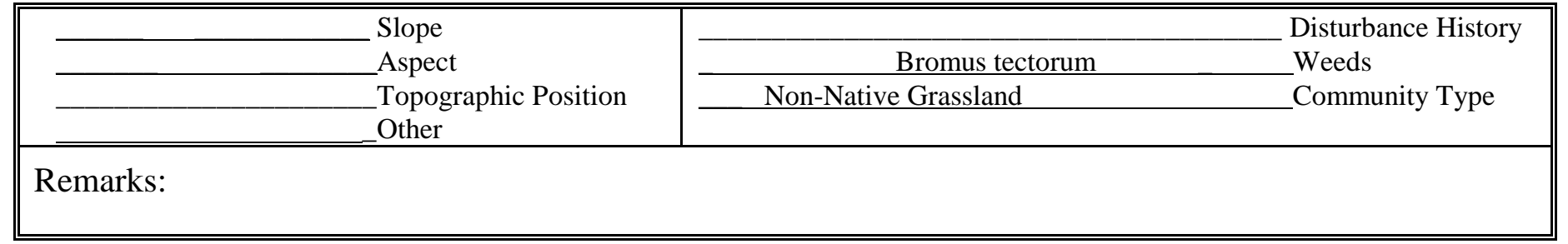

\section{SOILS}

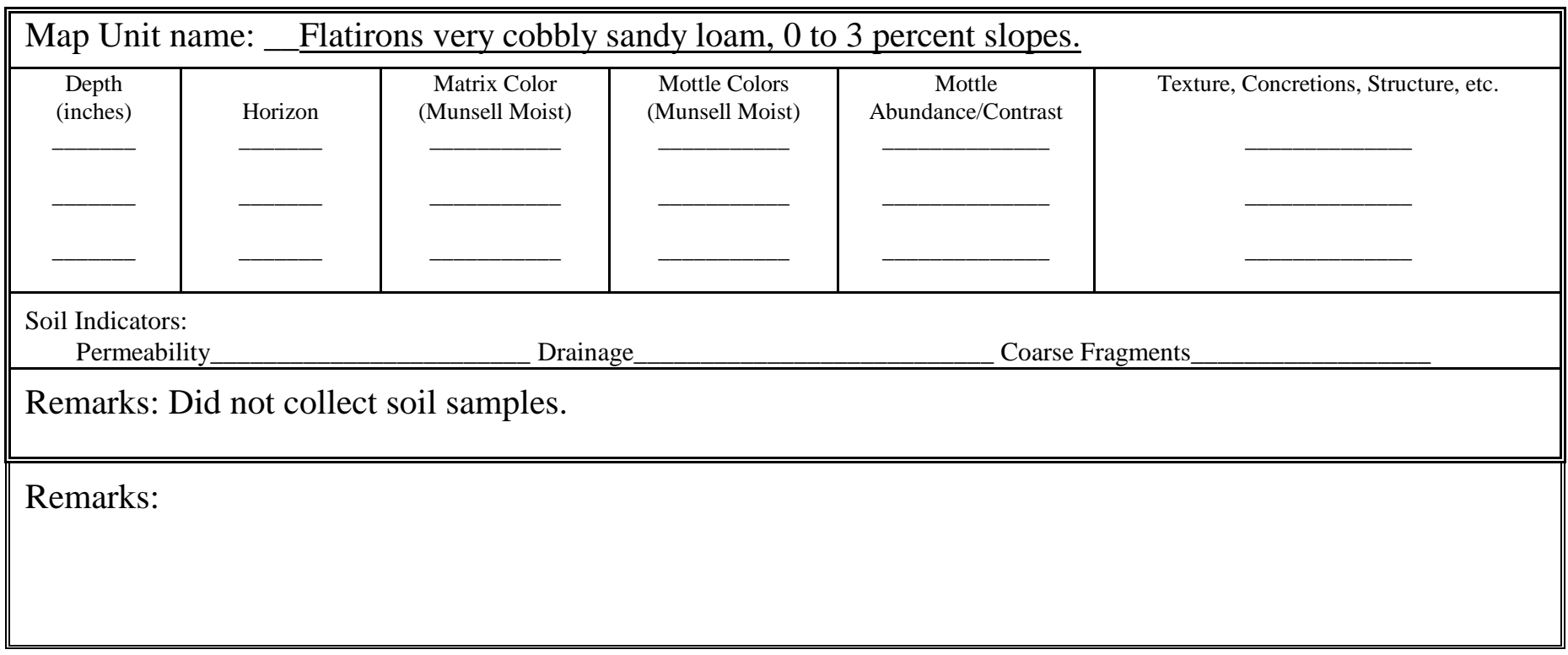




\begin{tabular}{||l|l|l||}
\hline $\begin{array}{l}\text { Project/Site: } \\
\text { Investigator: }\end{array}$ & Tony Romano & $\begin{array}{l}\text { Date: 8/9/2016 } \\
\text { County/State_CO }\end{array}$ \\
\hline \hline
\end{tabular}

VEGETATION
\begin{tabular}{||l|l||}
\hline Dom. Plant Species & Rel. \% \\
\hline 1 Poa pratensis & 25 \\
\hline 2 Bromus inermis & 15 \\
\hline 3 Aristida purpurea & 10 \\
\hline 4 Bromus tectorum & 7 \\
\hline 5 Panicum virgatum & 7 \\
\hline 6 Andropogon gerardii & 7 \\
\hline 7 Bouteloua gracilis & 7 \\
\hline 8 Psoralidium tenuiflorum & 3 \\
\hline 9 Koeleria macrantha & 3 \\
\hline 10 Heterotheca villosa & 3 \\
\hline 11 Rhus trilobata & 3 \\
\hline 12 Artemisia ludoviciana & 2 \\
\hline
\end{tabular}

\begin{tabular}{|l|l||}
\hline Dom. Plant Species & Rel. \% \\
\hline 13 Ratibida columnifera & 2 \\
\hline 14 Centaurea diffusa & 2 \\
\hline $\begin{array}{l}15 \text { Thelesperma } \\
\text { megapotamicum }\end{array}$ & 1 \\
\hline 16 Elymus elymoides & 1 \\
\hline 17 Helianthus pumilus & 1 \\
\hline 18 Liatris punctata & 1 \\
\hline 19 & \\
\hline 20 & \\
\hline 21 & \\
\hline 22 & \\
\hline 23 & \\
\hline 24 & \\
\hline
\end{tabular}

Remarks: Mixed Grassland, Kentucky Bluegrass is dominant, but much higher native cover than in other areas.

\section{TOPOGRAPHY/GEOLOGY/SITE CONDITIONS}

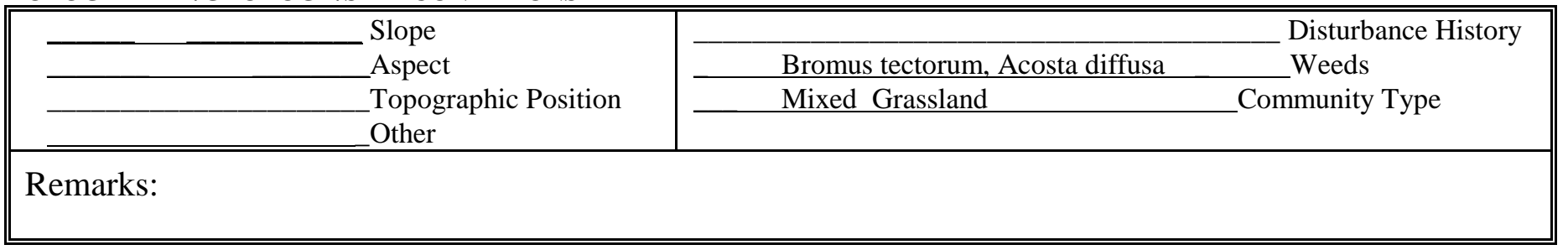

\section{SOILS}

\begin{tabular}{|c|c|c|c|c|c|}
\hline \multicolumn{6}{|c|}{ Map Unit name: __ Flatirons very cobbly sandy loam, 0 to 3 percent slopes. } \\
\hline $\begin{array}{c}\text { Depth } \\
\text { (inches) }\end{array}$ & Horizon & $\begin{array}{l}\text { Matrix Color } \\
\text { (Munsell Moist) }\end{array}$ & $\begin{array}{l}\text { Mottle Colors } \\
\text { (Munsell Moist) }\end{array}$ & $\begin{array}{c}\text { Mottle } \\
\text { Abundance/Contrast }\end{array}$ & Texture, Concretions, Structure, etc. \\
\hline \multirow{2}{*}{\multicolumn{6}{|c|}{$\begin{array}{l}\text { Soil Indicators: } \\
\text { Permeability }\end{array}$}} \\
\hline & & & & & \\
\hline \multicolumn{6}{|c|}{ Remarks: Did not collect soil samples. } \\
\hline \multicolumn{6}{|c|}{ Remarks: } \\
\hline
\end{tabular}


DATA FORM - Vegetation Inventory

\begin{tabular}{||l|l|l||}
\hline $\begin{array}{l}\text { Project/Site: } \\
\text { Investigator: }\end{array}$ & NWTC & $\begin{array}{l}\text { Date: 8/9/2016 } \\
\text { County/State_CO Romano }\end{array}$ \\
\hline \hline
\end{tabular}

VEGETATION
\begin{tabular}{|l|l||}
\hline Dom. Plant Species & Rel. \% \\
\hline 1 Bromus tectorum & 35 \\
\hline 2 Poa pratensis & 15 \\
\hline 3 Bromus inermis & 10 \\
\hline 4 Poa compressa & 10 \\
\hline 5 Aristida purpurea & 7 \\
\hline 6 Verbascum thapsus & 7 \\
\hline 7 Yucca glauca & 3 \\
\hline 8 Psoralidium tenuiflorum & 3 \\
\hline 9 Ratibida columnifera & 2 \\
\hline 10 Heterotheca villosa & 2 \\
\hline 11 Thelesperma megapotamicum & 2 \\
\hline 12 Artemisia ludoviciana & 2 \\
\hline
\end{tabular}

\begin{tabular}{|l|l||}
\hline Dom. Plant Species & Rel. $\%$ \\
\hline 13 Centaurea diffusa & 2 \\
\hline 14 & \\
\hline 16 & \\
\hline 17 & \\
\hline 18 & \\
\hline 19 & \\
\hline 20 & \\
\hline 21 & \\
\hline 22 & \\
\hline 23 & \\
\hline 24 & \\
\hline
\end{tabular}

\section{TOPOGRAPHY/GEOLOGY/SITE CONDITIONS}

\begin{tabular}{|c|c|}
\hline $\begin{array}{ll} & \text { Slope } \\
\text { Aspect } \\
\text { Topographic Position } \\
\text { Other }\end{array}$ & $\begin{array}{ll} & \text { Disturbance History } \\
\text { Bromus tectorum, Acosta diffusa } & \text { Weeds } \\
\text { Disturbed Grassland } & \text { Community Type }\end{array}$ \\
\hline marks: & \\
\hline
\end{tabular}

\section{SOILS}

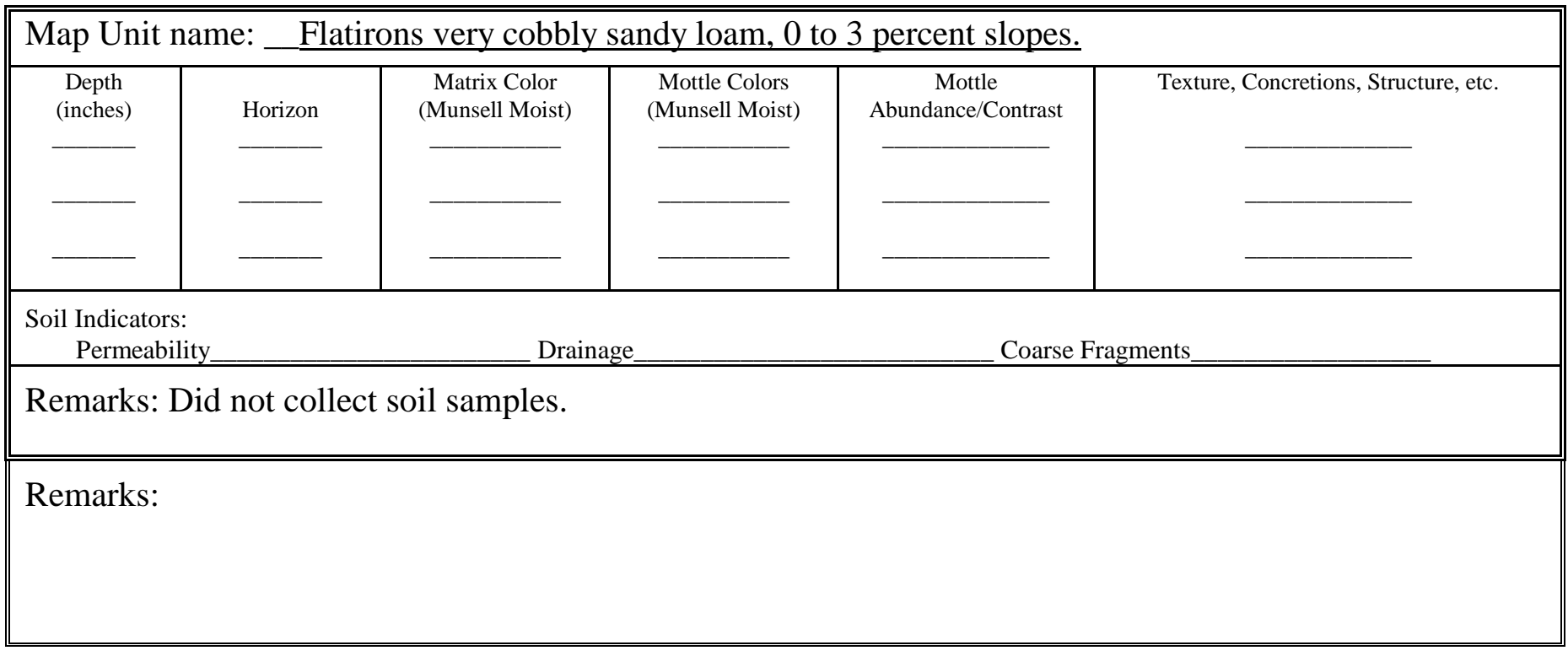


DATA FORM - Vegetation Inventory

\begin{tabular}{||l|l|l||}
\hline $\begin{array}{l}\text { Project/Site: } \\
\text { Investigator: }\end{array}$ & NWTC & $\begin{array}{l}\text { Date: 8/9/2016 } \\
\text { County/State_CO Romano }\end{array}$ \\
\hline \hline
\end{tabular}

VEGETATION
\begin{tabular}{||l|l||}
\hline Dom. Plant Species & Rel. \% \\
\hline 1 Panicum virgatum & 15 \\
\hline 2 Poa compressa & 15 \\
\hline 3 Aristida purpurea & 15 \\
\hline 4 Poa pratensis & 10 \\
\hline 5 Bromus inermis & 10 \\
\hline 6 Andropogon gerardii & 7 \\
\hline 7 Schizachyrium scoparium & 5 \\
\hline 8 Sorghastrum nutans & 5 \\
\hline 9 Hesperostipa comata & 5 \\
\hline 10 Dactylis glomerata & 3 \\
\hline 11 Heterotheca villosa & 2 \\
\hline 12 Artemisia frigida & 2 \\
\hline
\end{tabular}

\begin{tabular}{|l|l||}
\hline Dom. Plant Species & Rel. \% \\
\hline 13 Nassella viridula & 2 \\
\hline 14 Eriogonum alatum & 1 \\
\hline 15 Liatris punctata & 1 \\
\hline $\begin{array}{l}16 \text { Thelesperma } \\
\text { megapotamicum }\end{array}$ & 1 \\
\hline 17 Psoralidium tenuiflorum & 1 \\
\hline 18 & \\
\hline 19 & \\
\hline 20 & \\
\hline 21 & \\
\hline 22 & \\
\hline 23 & \\
\hline 24 & \\
\hline
\end{tabular}

Remarks: Mixed Grassland with higher native cover than in other areas.

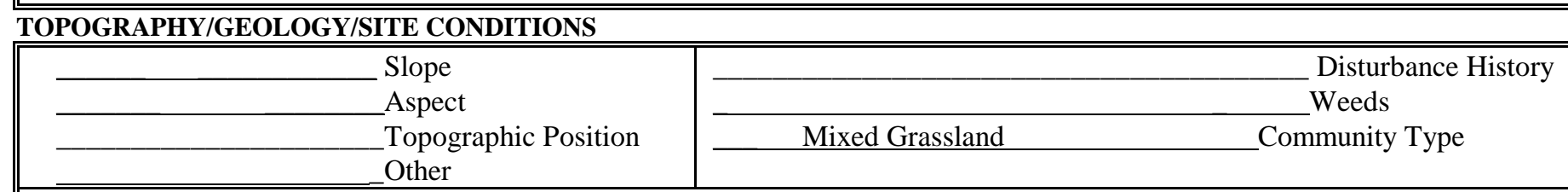

Remarks:

\section{SOILS}

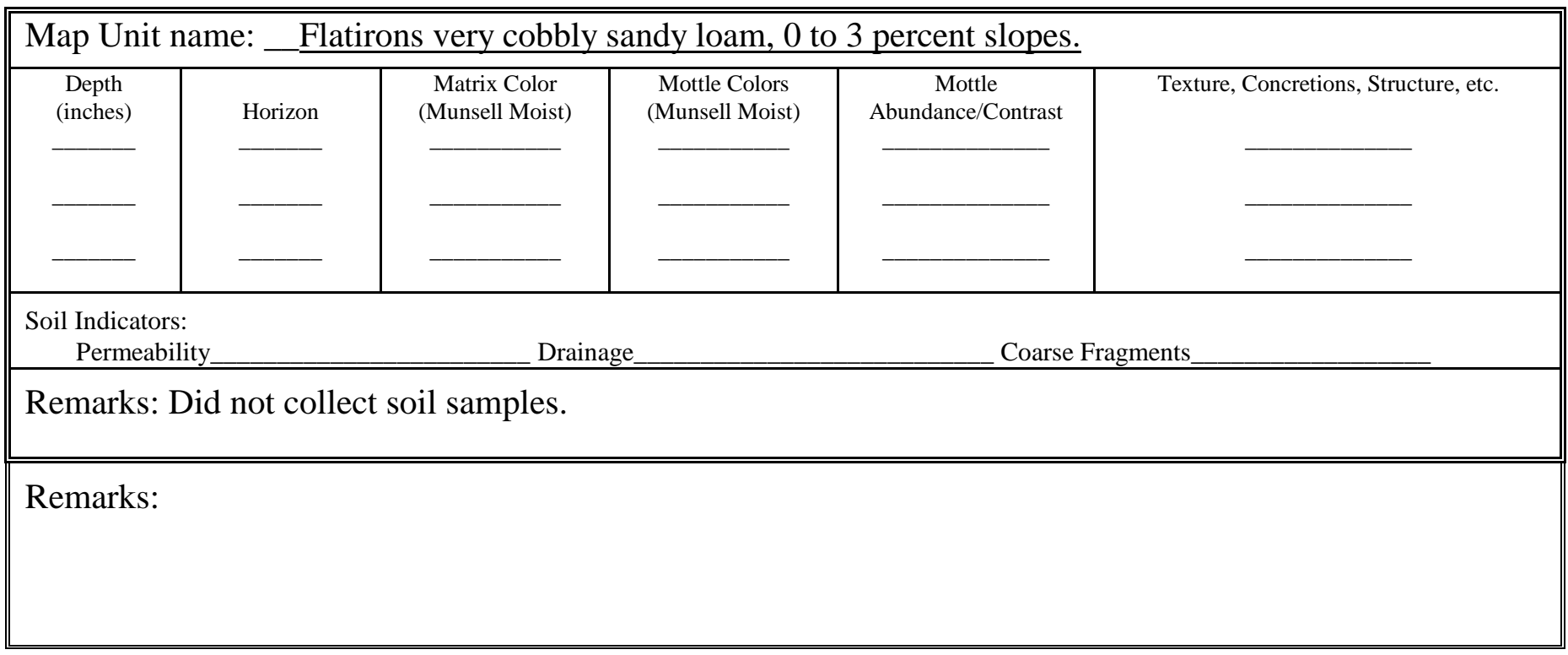


DATA FORM - Vegetation Inventory

Project/Site: $\quad$ NWTC

Investigator: $\quad$ Tony Romano

Date: $8 / 9 / 2016$

County/State_ $\mathrm{CO}$

\begin{tabular}{|c|c|}
\hline Dom. Plant Species & Rel. \% \\
\hline 1 Poa pratensis & 25 \\
\hline 2 Bromus inermis & 15 \\
\hline 3 Poa compressa & 10 \\
\hline 4 Aristida purpurea & 10 \\
\hline 5 Andropogon gerardii & 5 \\
\hline 6 Panicum virgatum & 5 \\
\hline 7 Thinopyrum intermedium & 5 \\
\hline 8 Artemisia ludoviciana & 3 \\
\hline 9 Psoralidium tenuiflorum & 3 \\
\hline 10 Opuntia macrorhiza & 3 \\
\hline 11 Koeleria macrantha & 2 \\
\hline 12 Pascopyrum smithii & 2 \\
\hline
\end{tabular}

\begin{tabular}{||l|l||}
\hline Dom. Plant Species & Rel. \% \\
\hline 13 Yucca glauca & 2 \\
\hline 15 Linaria dalmatica & 1 \\
\hline 16 Heterotheca villosa & 1 \\
\hline 17 Liatris punctata & 1 \\
\hline 18 Prunus virginiana & 1 \\
\hline 19 Elymus elymoides & 1 \\
\hline 20 Bouteloua curtipendula & 1 \\
\hline 21 Dactylis glomerata & 1 \\
\hline 22 Hesperostipa comata & 1 \\
\hline 23 & \\
\hline 24 & \\
\hline
\end{tabular}

Remarks: Mixed Grassland, Kentucky Bluegrass is dominant, but much higher native cover than in other areas.

\section{TOPOGRAPHY/GEOLOGY/SITE CONDITIONS}

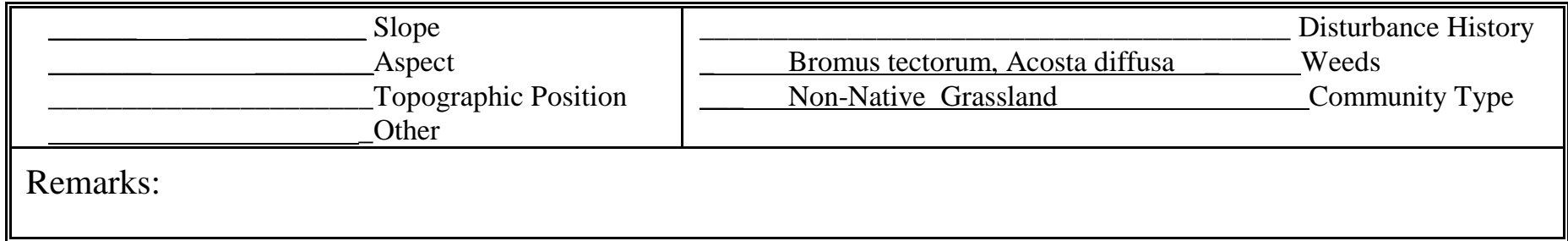

SOILS

Map Unit name: __ Flatirons very cobbly sandy loam, 0 to 3 percent slopes.

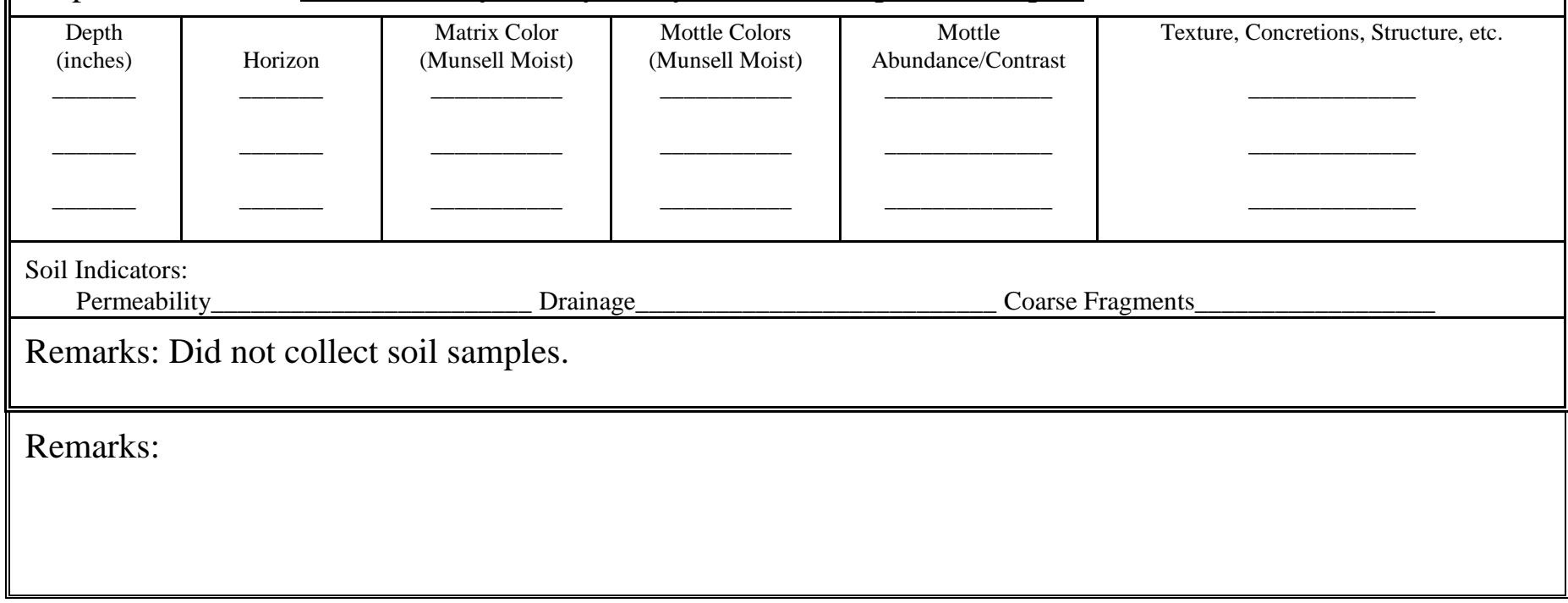


Project/Site: $\quad$ NWTC

Investigator: $\quad$ Tony Romano

Date: $8 / 9 / 2016$

County/State_ $\mathrm{CO}$

VEGETATION
\begin{tabular}{||l|l||}
\hline Dom. Plant Species & Rel. \% \\
\hline 1 Poa pratensis & 20 \\
\hline 2 Bromus inermis & 15 \\
\hline 3 Poa compressa & 15 \\
\hline 4 Aristida purpurea & 10 \\
\hline 5 Andropogon gerardii & 5 \\
\hline 6 Panicum virgatum & 5 \\
\hline 7 Thinopyrum intermedium & 5 \\
\hline 8 Artemisia ludoviciana & 3 \\
\hline 9 Psoralidium tenuiflorum & 2 \\
\hline 10 Opuntia macrorhiza & 2 \\
\hline 11 Koeleria macrantha & 2 \\
\hline 12 Pascopyrum smithii & 2 \\
\hline Remarks Mixed Grassand Kentucky B
\end{tabular}

\begin{tabular}{|l|l||}
\hline Dom. Plant Species & Rel. \% \\
\hline 13 Yucca glauca & 2 \\
\hline 14 Eriogonum alatum & 1 \\
\hline 15 Linaria dalmatica & 1 \\
\hline 16 Heterotheca villosa & 1 \\
\hline 17 Liatris punctata & 1 \\
\hline 18 Prunus virginiana & 1 \\
\hline 19 Elymus elymoides & 1 \\
\hline 20 Bouteloua curtipendula & 1 \\
\hline 21 Dactylis glomerata & 1 \\
\hline 22 Hesperostipa comata & 1 \\
\hline 23 Lactuca serriola & 1 \\
\hline 24 Sorghastrum nutans & 1 \\
\hline minant, but much higher native cover than in other
\end{tabular}

Remarks: Mixed Grassland, Kentucky Bluegrass is dominant, but much higher native cover than in other areas.

\section{TOPOGRAPHY/GEOLOGY/SITE CONDITIONS}

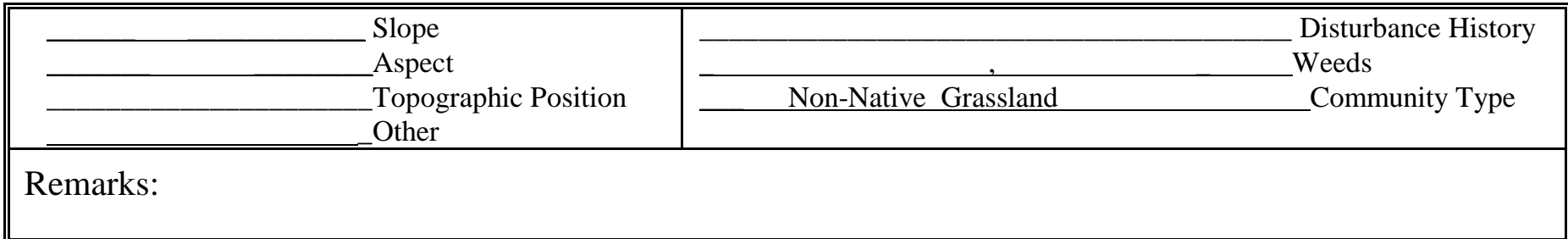

SOILS

Map Unit name: __ Flatirons very cobbly sandy loam, 0 to 3 percent slopes.

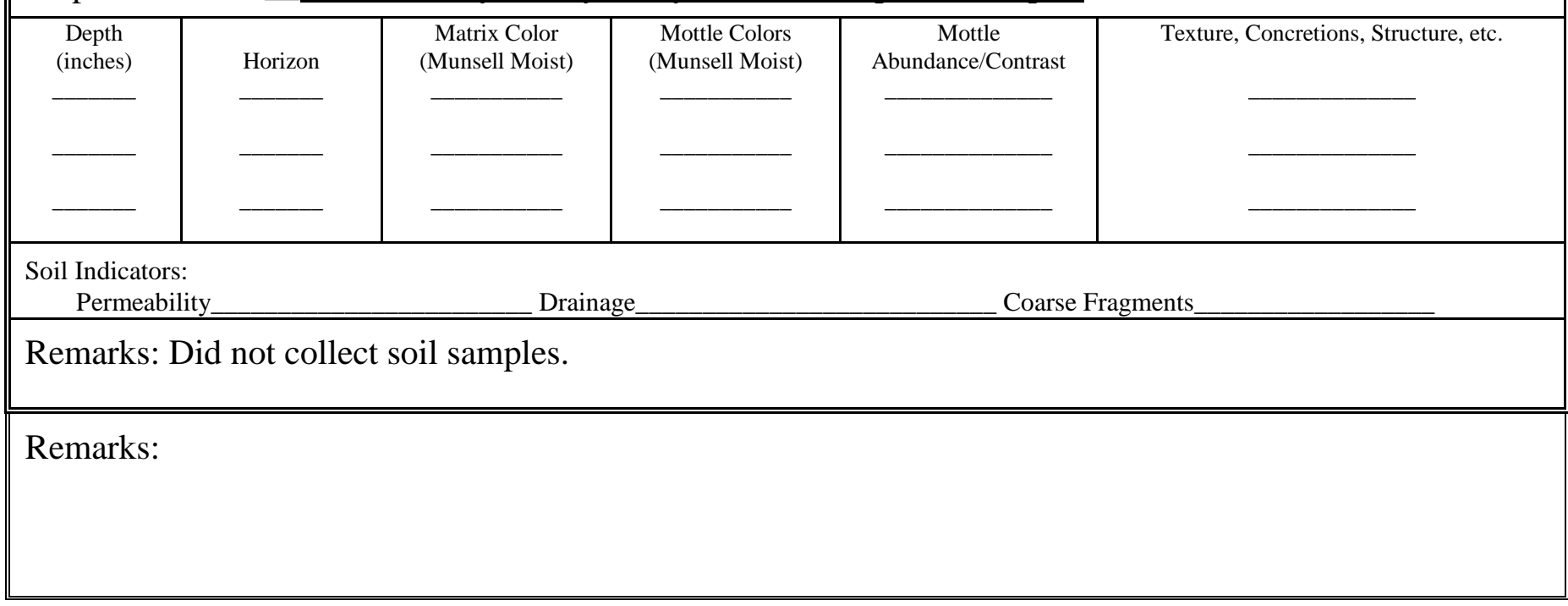


2016 Wildlife and Vegetation Monitoring Report

National Wind Technology Center

Jefferson County, Colorado

Appendix B List of Species Observed During the 2016 Field Surveys

ERO Resources Corporation

This report is available at no cost from the National Renewable Energy Laboratory (NREL) at www.nrel.gov/publications 


\begin{tabular}{|c|c|c|}
\hline Common Name & Scientific Name & Status \\
\hline \multicolumn{3}{|l|}{ Trees } \\
\hline Plains cottonwood & Populus deltoides & Native \\
\hline Ponderosa pine & Pinus ponderosa & Native \\
\hline \multicolumn{3}{|l|}{ Shrubs } \\
\hline Chokecherry & Prunus virginiana & Native \\
\hline Hen-and-Chickens & Echinocereus viridiflorus & Native \\
\hline Plain pricklypear & Opuntia polyacantha & Native \\
\hline Sandbar willow & Salix exigua & Native \\
\hline Skunkbrush sumac & Rhus trilobata & Native \\
\hline Twistpine prickly pear & Opuntia macrorhiza & Native \\
\hline Wax currant & Ribes cereum & Native \\
\hline Western poison ivy & Toxicodendron rybergii & Native \\
\hline Western serviceberry & Amelanchier alnifolia & Native \\
\hline Western snowberry & Symphoricarpos occidentalis & Native \\
\hline Wild plum & Prunus americana & Native \\
\hline Wood's rose & Rosa woodsii & Native \\
\hline Yucca & Yucca glauca & Native \\
\hline \multicolumn{3}{|l|}{ Grasses (Poaceae) } \\
\hline Barnyard grass & Echinochloa crus-galli & Introduced \\
\hline Big bluestem & Andropogon gerardii & Native \\
\hline Blue grama & Bouteloua gracilis & Native \\
\hline Broadleaf cattail & Typha latifolia & Native \\
\hline Buffalo grass & Bouteloua dactyloides & Native \\
\hline Canada bluegrass & Poa compressa & Introduced \\
\hline Canada wildrye & Elymus canadensis & Native \\
\hline Crested wheatgrass & Agropyron cristatum & Introduced \\
\hline Foxtail barley & Hordeum jubatum & Native \\
\hline Green needlegrass & Nassella viridula & Native \\
\hline Intermediate wheatgrass & Thinopyrum intermedium & Introduced \\
\hline Field brome & Bromus arvensis & Introduced \\
\hline Junegrass & Koeleria macrantha & Native \\
\hline Kentucky bluegrass & Poa pratensis & Introduced \\
\hline Little bluestem & Schizachyrium scoparium & Native \\
\hline Meadow barley & Hordeum brachyantherum & Native \\
\hline Meadow fescue & Schedonorus pratensis & Introduced \\
\hline Narrowleaf cattail & Typha angustifolia & Native \\
\hline Needle and thread grass & Hesperostipa comata & Native \\
\hline Orchard grass & Dactylis glomerata & Introduced \\
\hline Perennial ryegrass & Lolium perenne & Introduced \\
\hline Prairie cordgrass & Spartina pectinata & Native \\
\hline Rabbitfoot grass & Polypogon monspeliensis & Introduced \\
\hline Redtop & Agrostis gigantea & Introduced \\
\hline Sand dropseed & Sporobolus cryptandrus & Native \\
\hline Sideoats grama & Bouteloua curtipendula & Native \\
\hline Slender wheatgrass & Elymus trachycaulus & Native \\
\hline Smooth brome & Bromus inermis & Introduced \\
\hline
\end{tabular}




\begin{tabular}{|c|c|c|}
\hline Squirreltail & Elymus elymoides & Native \\
\hline Switchgrass & Panicum virgatum & Native \\
\hline Tall wheatgrass & Thinopyrum ponticum & Introduced \\
\hline Thickspike wheatgrass & Elymus lanceolatus & Native \\
\hline Threeawn & Aristida purpurea & Native \\
\hline Western wheatgrass & Pascopyrum smithii & Native \\
\hline Yellow indiangrass & Sorghastrum nutans & Native \\
\hline \multicolumn{3}{|l|}{ Rushes (Juncaceae) } \\
\hline Arctic rush & Juncus arcticus & Native \\
\hline Dudley's rush & Juncus dudleyi & Native \\
\hline Longstyle rush & Juncus longistylis & Native \\
\hline Longstyle rush & Juncus ensifolius & Native \\
\hline Rush species & Juncus sp. & $\mathrm{n} / \mathrm{a}$ \\
\hline Torrey's rush & Juncus torreyi & Native \\
\hline \multicolumn{3}{|l|}{ Sedges (Cyperaceae) } \\
\hline Cloaked bulrush & Scirpus pallidus & Native \\
\hline Common spikerush & Eleocharis palustris & Native \\
\hline Common threesquare & Schoenoplectus pungens & Native \\
\hline Emory's sedge & Carex emoryi & Native \\
\hline Nebraska sedge & Carex nebrascensis & Native \\
\hline Plains oval sedge & Carex brevior & Native \\
\hline Softstem bulrush & Schoenoplectus tabernaemontani & Native \\
\hline \multicolumn{3}{|l|}{ Forbs } \\
\hline Alyssum & Alyssum simplex & Introduced \\
\hline Annual sunflower & Helianthus annuus & Native \\
\hline Blanket flower & Gaillardia aristata & Native \\
\hline Bracted verbena & Verbena bracteata & Native \\
\hline Buffalo burr & Solanum rostratum & Native \\
\hline Canada horseweed & Conyza canadensis & Native \\
\hline Catnip & Nepeta cataria & Introduced \\
\hline Common yarrow & Achillea millefolium & Native \\
\hline Curly cup gumweed & Grindelia squarrosa & Native \\
\hline Curly dock & Rumex crispus & Introduced \\
\hline Erigeron species & Erigeron sp. & Native \\
\hline Fringed sage & Artemisia frigida & Native \\
\hline Globe mallow & Sphaeralcea coccinea & Native \\
\hline Golden banner & Thermopsis rhombifolia & Native \\
\hline Hairy evening primrose & Oenothera villosa & Native \\
\hline Hairy golden aster & Heterotheca villosa & Native \\
\hline Harebell & Campanula rotundifolia & Native \\
\hline Velvetweed & Oenothera curtiflora & Native \\
\hline Hooker's evening primrose & Oenothera elata & Native \\
\hline Hopi tea & Thelesperma megapotamicum & Native \\
\hline Indian hemp & Apocynum cannabinum & Native \\
\hline James' nailwort & Paronychia jamesii & Native \\
\hline Kochia & Bassia scoparia & Introduced \\
\hline Little sunflower & Helianthus pumilus & Native \\
\hline
\end{tabular}




\begin{tabular}{|c|c|c|}
\hline Marbleseed & Onosmodium bejariense & Native \\
\hline Perennial ragweed & Ambrosia psilostachya & Native \\
\hline Prairie coneflower & Ratibida columnifera & Native \\
\hline Prairie gayfeather & Liatris punctata & Native \\
\hline Prairie sage & Artemisia ludoviciana & Introduced \\
\hline Prickly lettuce & Lactuca serriola & Introduced \\
\hline Purple locoweed & Oxytropis lambertii & Native \\
\hline Rosy pussytoes & Antennaria rosea & Native \\
\hline Salsify & Tragopogon dubius & Introduced \\
\hline Scurf pea & Psoralidium tenuiflorum & Native \\
\hline Sego lily & Calochortus gunnisonii & Native \\
\hline Showy milkweed & Asclepias speciosa & Native \\
\hline Sidebells penstemon & Penstemon secundiflorus & Native \\
\hline Solidago species & Solidago sp. & Native \\
\hline Dotted smartweed & Polygonum punctatum & Native \\
\hline Sulphur flower & Eriogonum umbellatum & Native \\
\hline Swamp milkweed & Asclepias incarnata & Native \\
\hline Wavyleaf thistle & Cirsium undulatum & Native \\
\hline Wild licorice & Glycyrrhiza lepidota & Native \\
\hline Wild onion & Allium textile & Native \\
\hline Willow herb species & Epilobium sp. & Native \\
\hline Winged buckwheat & Eriogonum alatum & Native \\
\hline Yellow avens & Geum aleppicum & Native \\
\hline Yellow sweetclover & Melilotus officinalis & Introduced \\
\hline Water speedwell & Veronica sp. & Native \\
\hline White blazingstar & Mentzelia nuda & Native \\
\hline \multicolumn{3}{|l|}{ Noxious Weeds } \\
\hline Bull thistle & Cirsium vulgare & Noxious \\
\hline Canada thistle & Cirsium arvense & Noxious \\
\hline Common mullein & Verbascum thapsus & Noxious \\
\hline Common St. Johnswort & Hypericum perforatum & Noxious \\
\hline Common teasel & Dipsacus fullonum & Noxious \\
\hline Dalmation toadflax & Linaria dalmatica & Noxious \\
\hline Diffuse knapweed & Centaurea diffusa & Noxious \\
\hline Downy brome & Bromus tectorum & Noxious \\
\hline Field bindweed & Convolvulus arvensis & Noxious \\
\hline Moth mullein & Verbascum blattaria & Noxious \\
\hline Musk thistle & Carduus nutans & Noxious \\
\hline Quackgrass & Elymus repens & Noxious \\
\hline Redstem filaree & Erodium cicutarium & Noxious \\
\hline Sulphur cinquefoil & Potentilla recta & Noxious \\
\hline
\end{tabular}


2016 Wildlife and Vegetation Monitoring Report

National Wind Technology Center

Jefferson County, Colorado

Photo Log

ERO Resources Corporation

This report is available at no cost from the National Renewable Energy Laboratory (NREL) at www.nrel.gov/publications 
Рното LoG

National Wind Technology Center

2016 Baseline SurVeys

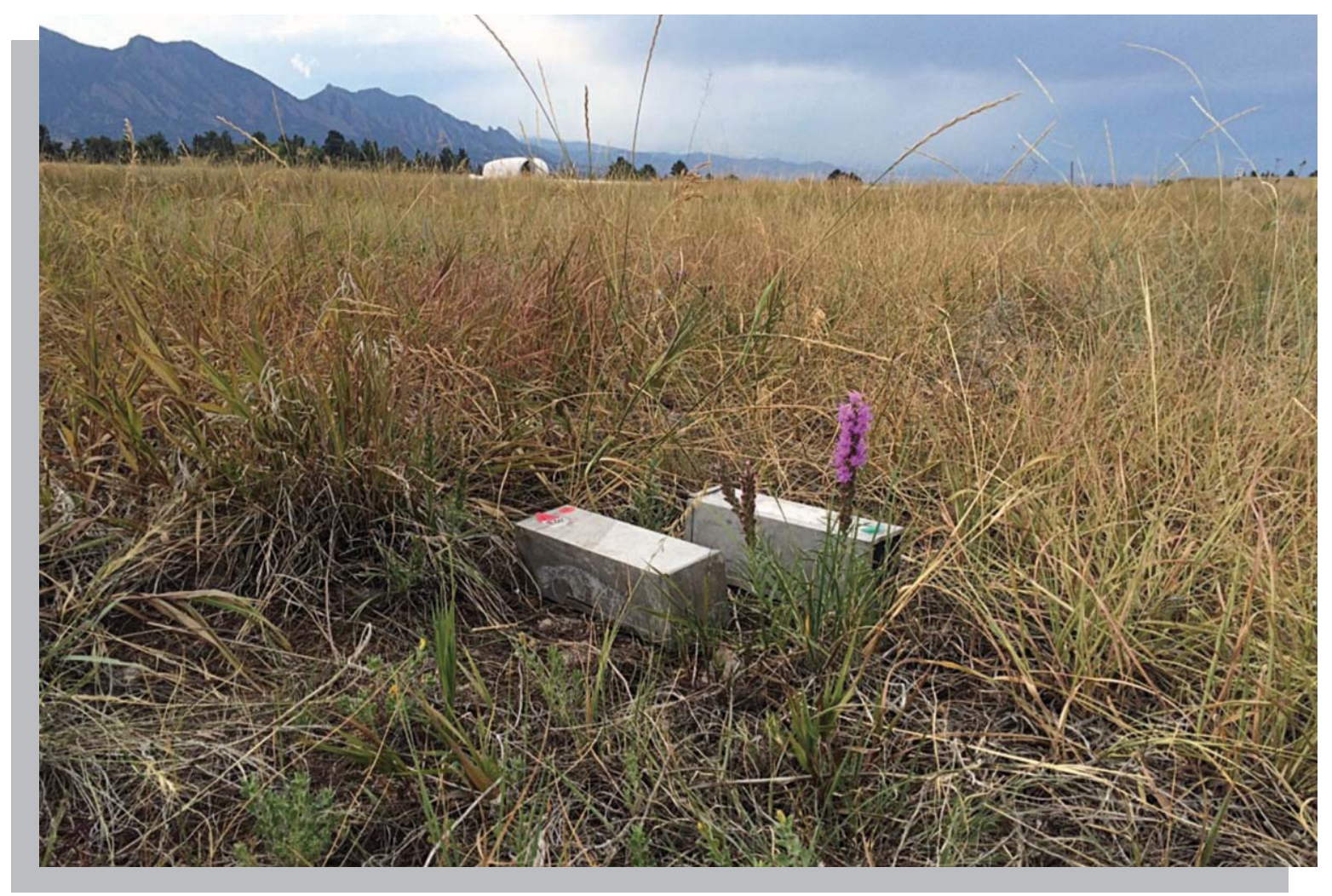

Photo 1 - Live trap set up along a transect in NWTC.

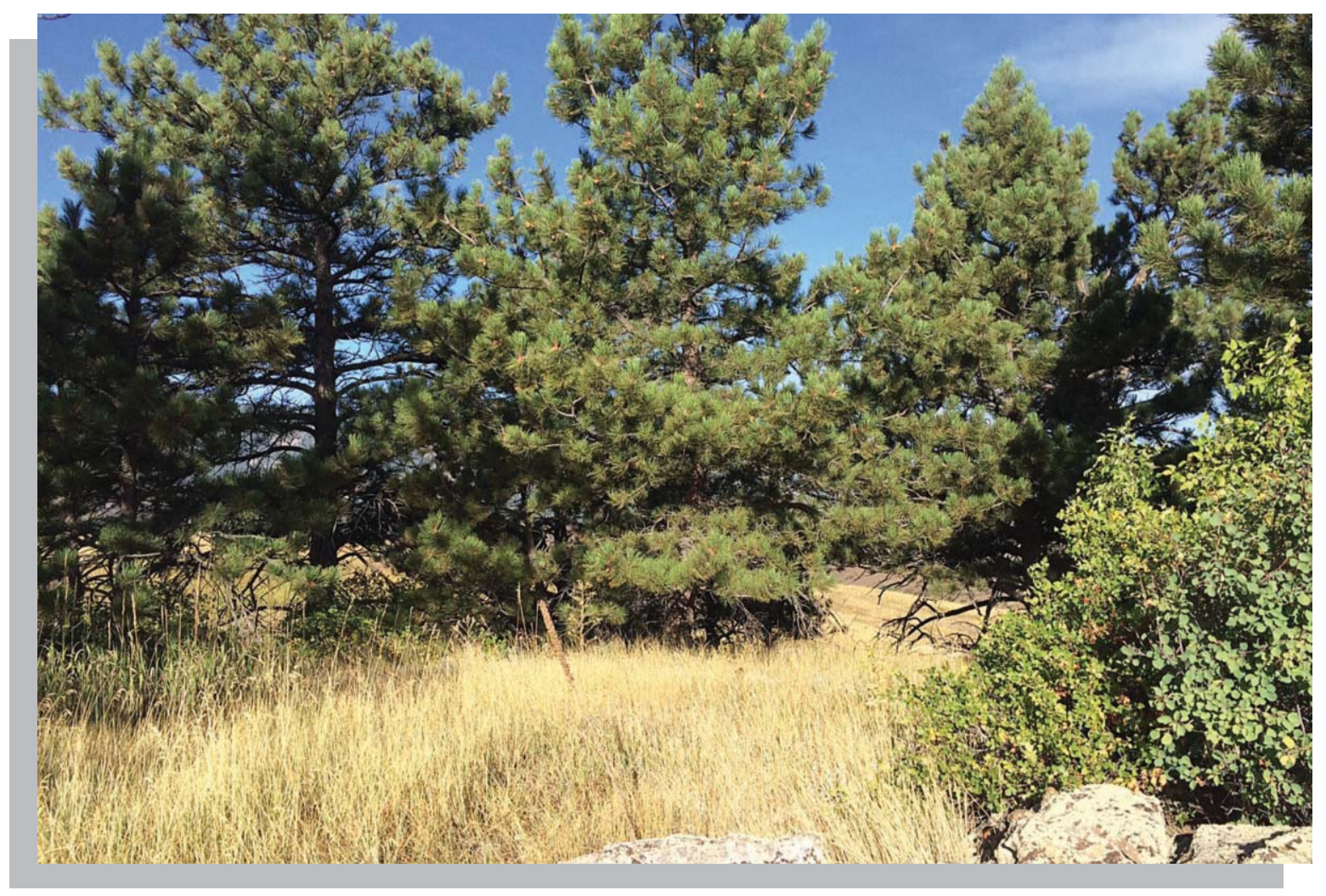

Photo 2 - Point count location \# 1 (west). 
Рното Log

National Wind Technology Center

2016 Baseline SurVeys

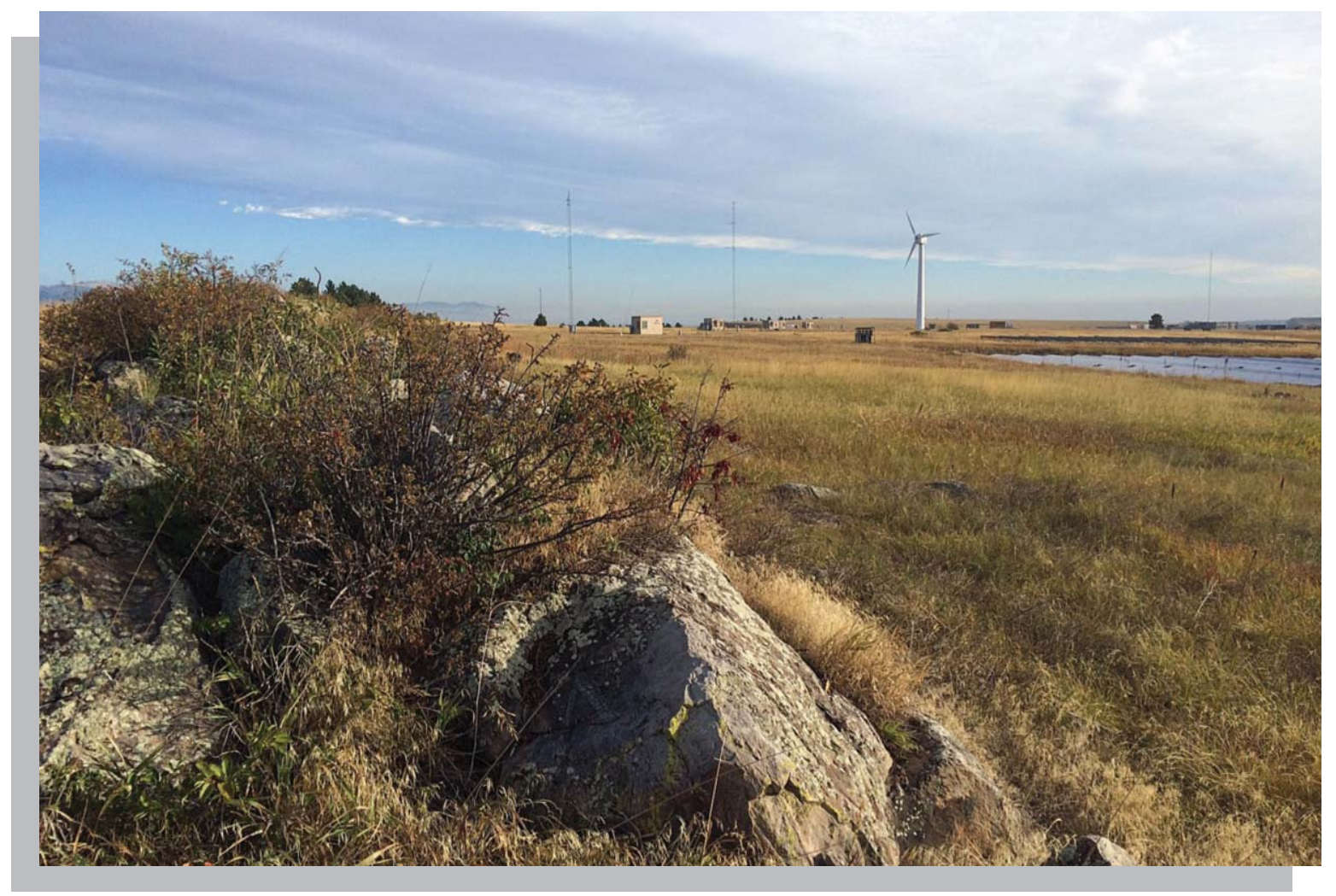

Photo 3 - Point count location \#2 (north).

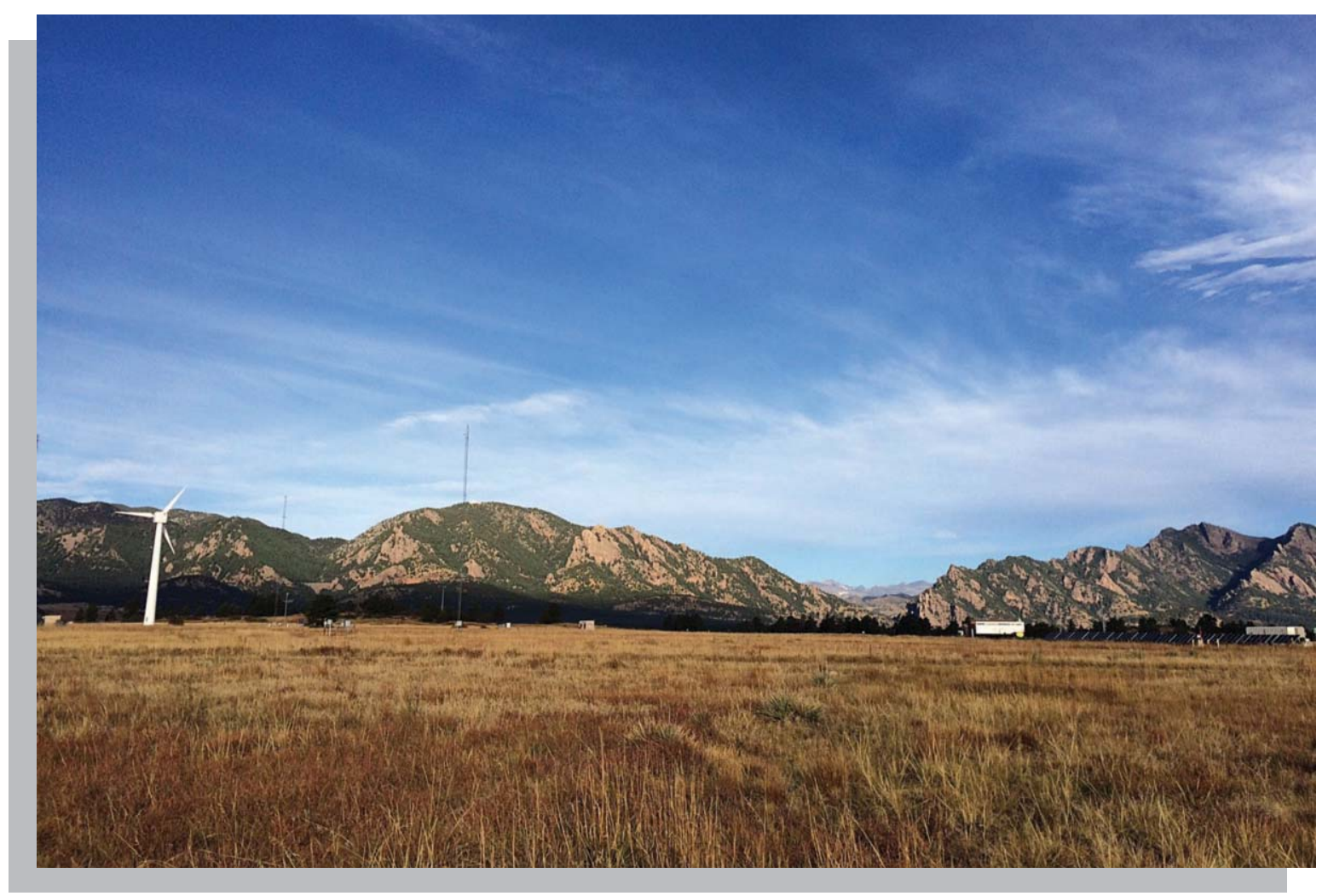

Photo 4 - Point count location \#3 (west). 
PнOTO LOG

National Wind Technology Center

2016 Baseline SurVeys

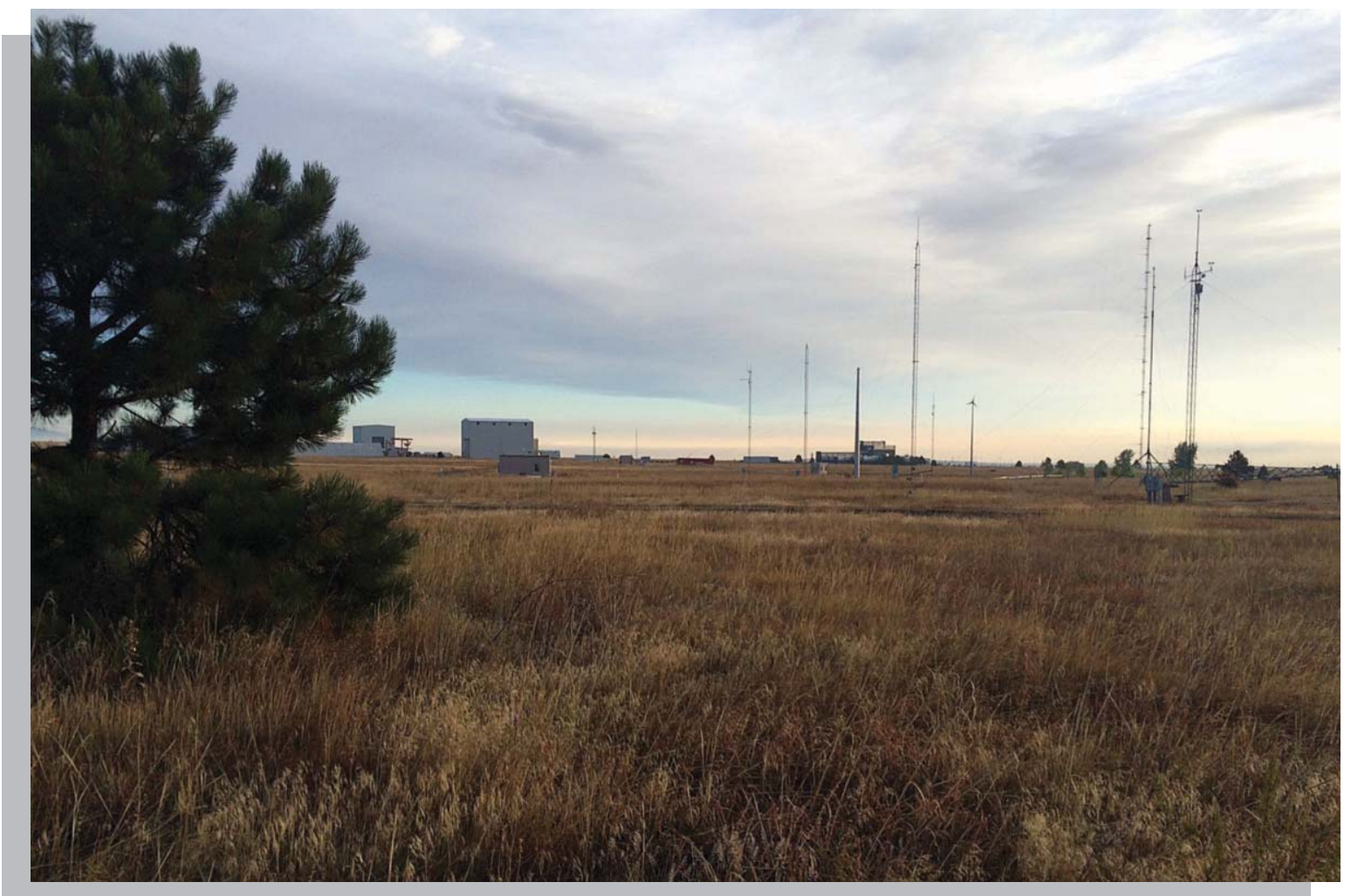

Photo 5 - Point count location \#4 (north).

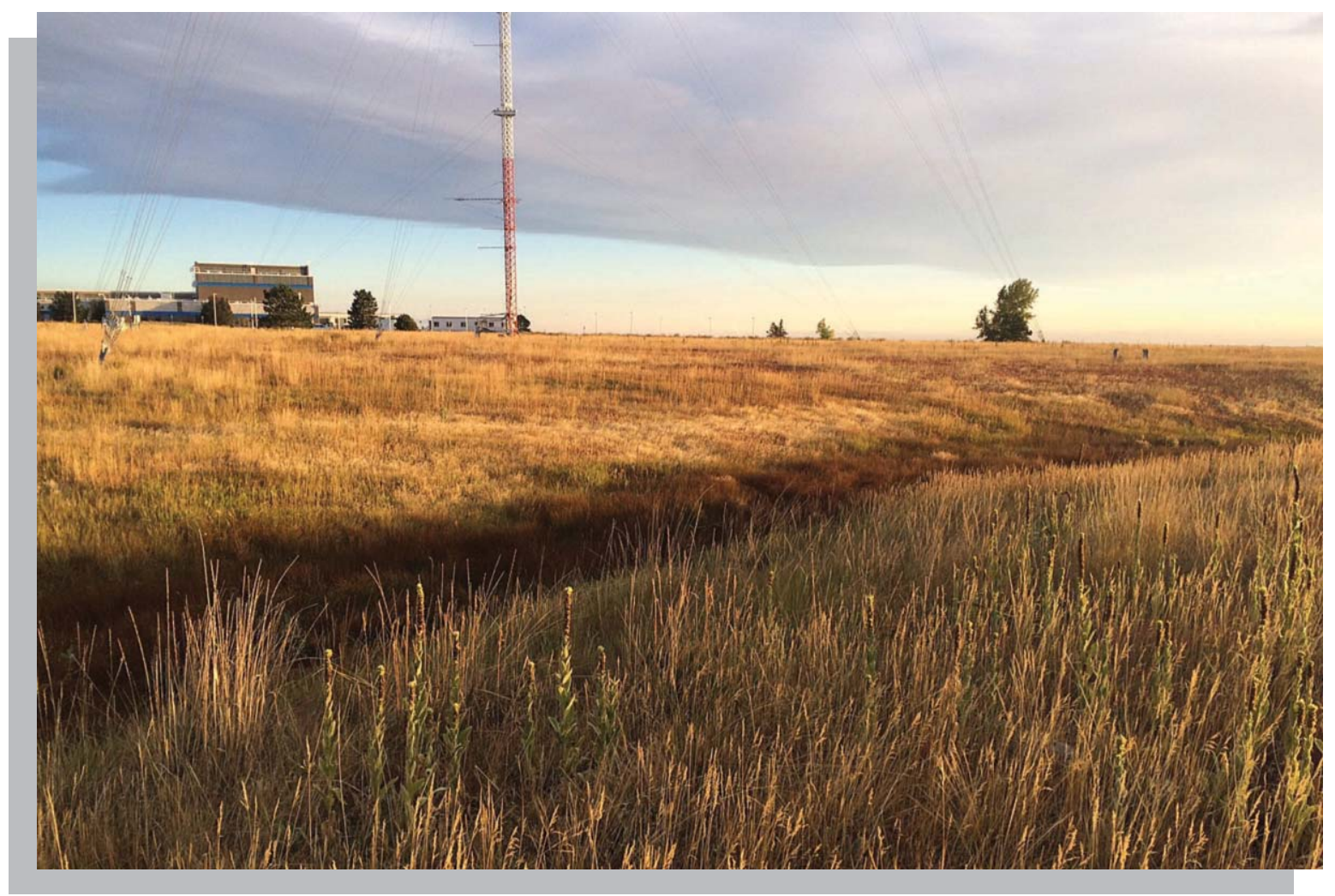

Photo 6 - Point count location \#5 (north). 
Рното Log

National Wind Technology Center

2016 Baseline SurVeys

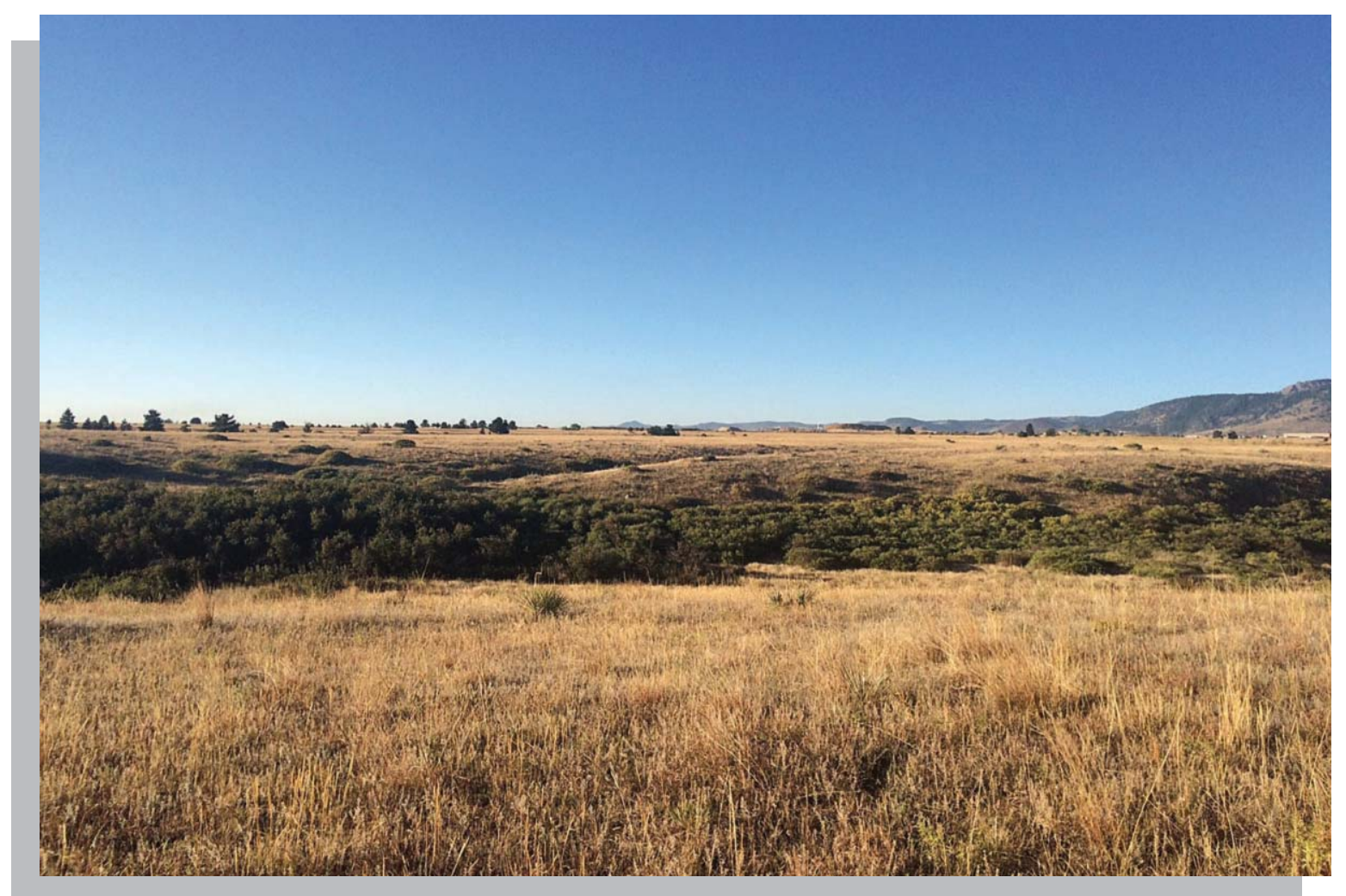

Photo 7 - Point count location \#6 (south).

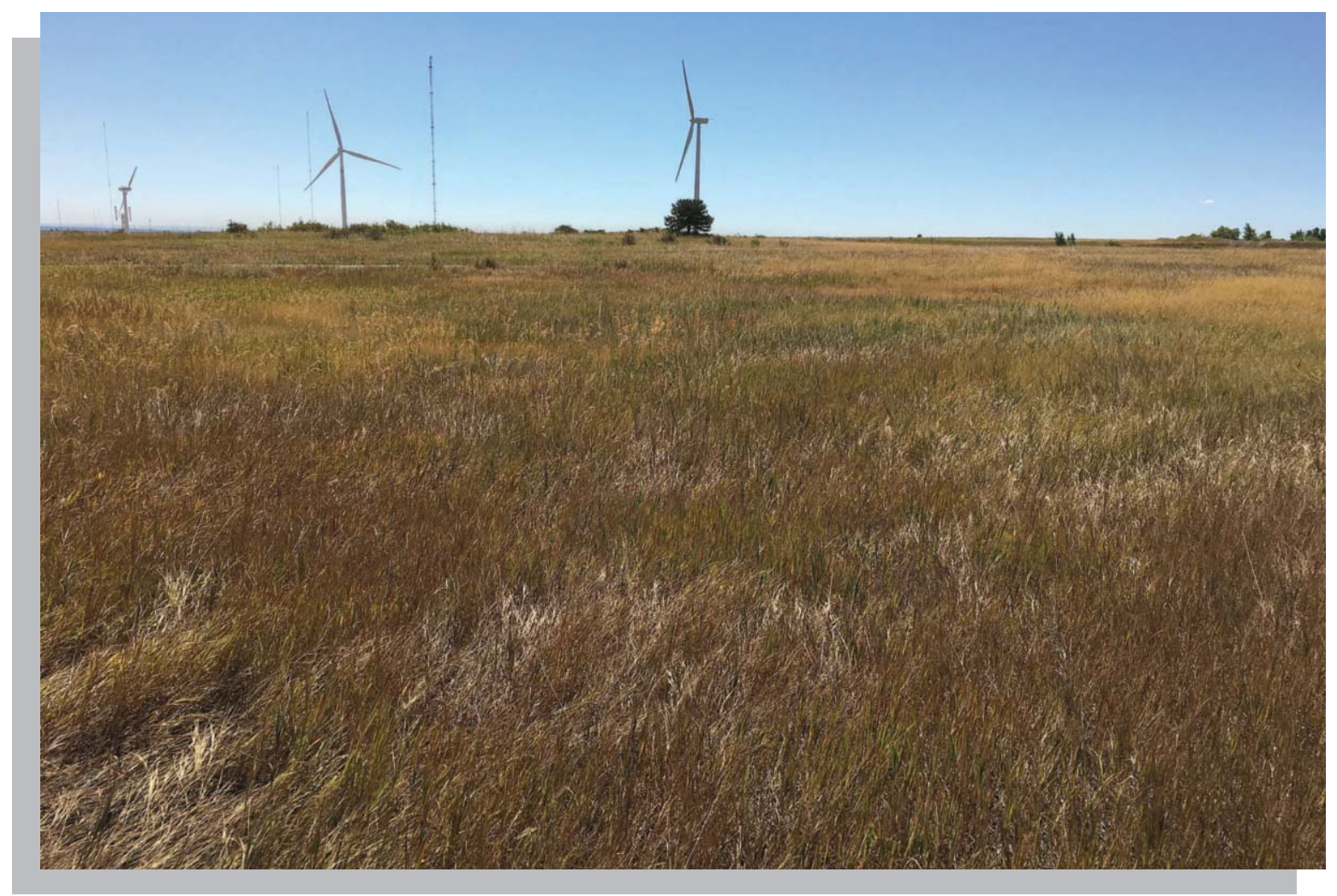

Photo 8 - Nonnative grasslands at NWTC.

This report is available at no cost from the National Renewable Energy Laboratory (NREL) at www.nrel.gov/publications 
Рното Log

National Wind Technology Center

2016 Baseline SurVeys

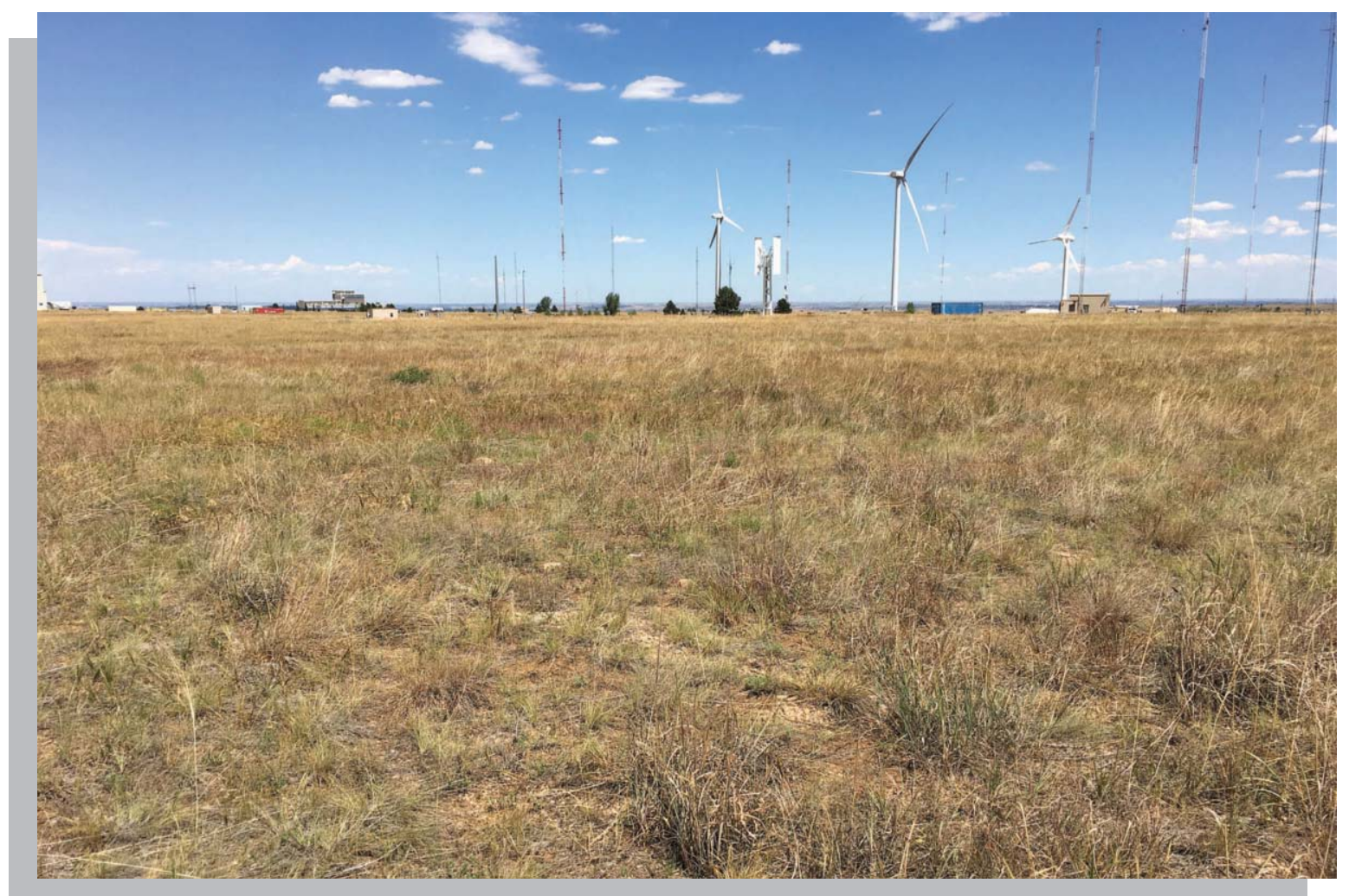

Photo 9 - Mixed grasslands at NWTC.

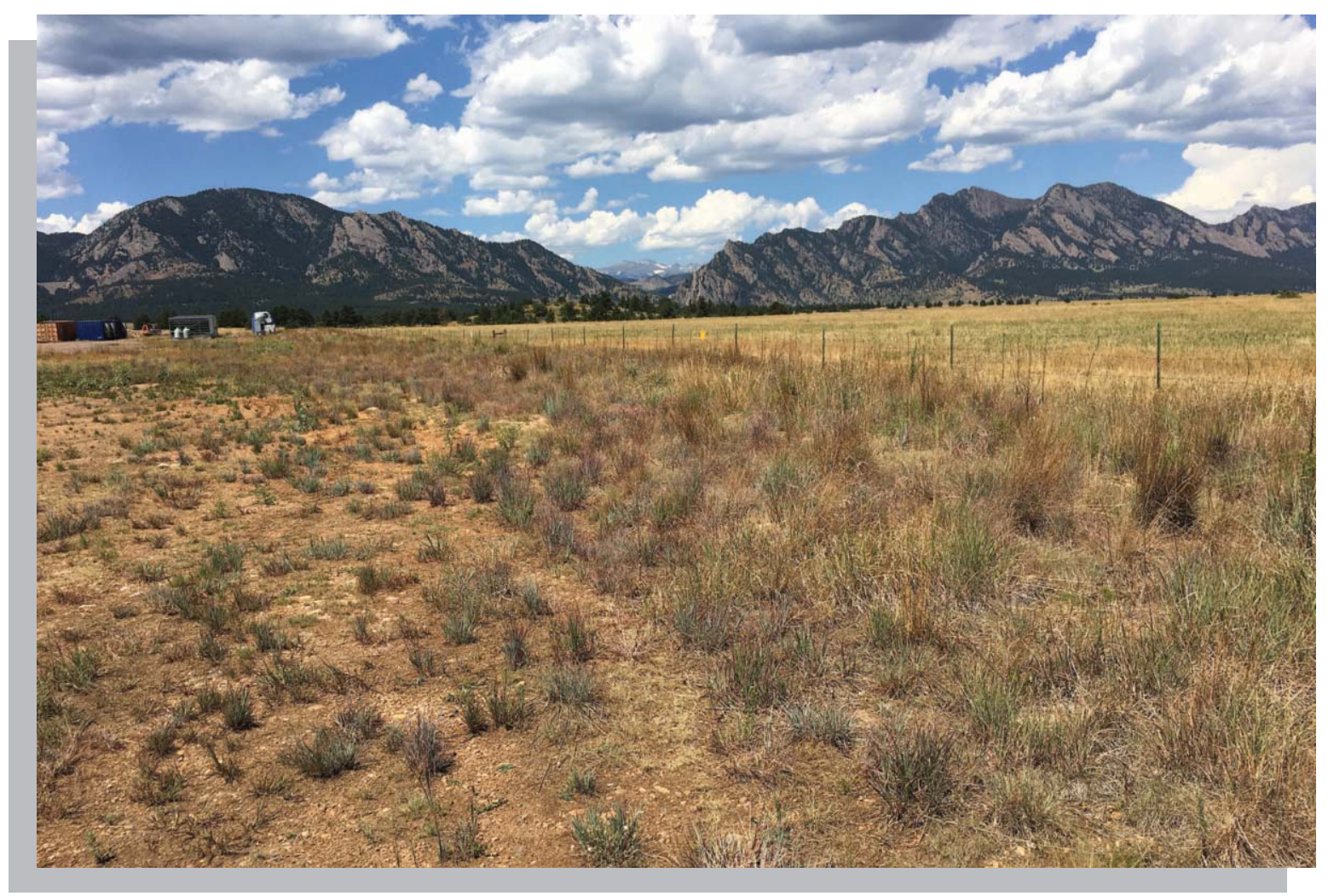

Photo 10 - Disturbed native grasslands at NWTC.

This report is available at no cost from the National Renewable Energy Laboratory (NREL) at www.nrel.gov/publications 
Рното Log

National Wind Technology Center

2016 Baseline SurVeys

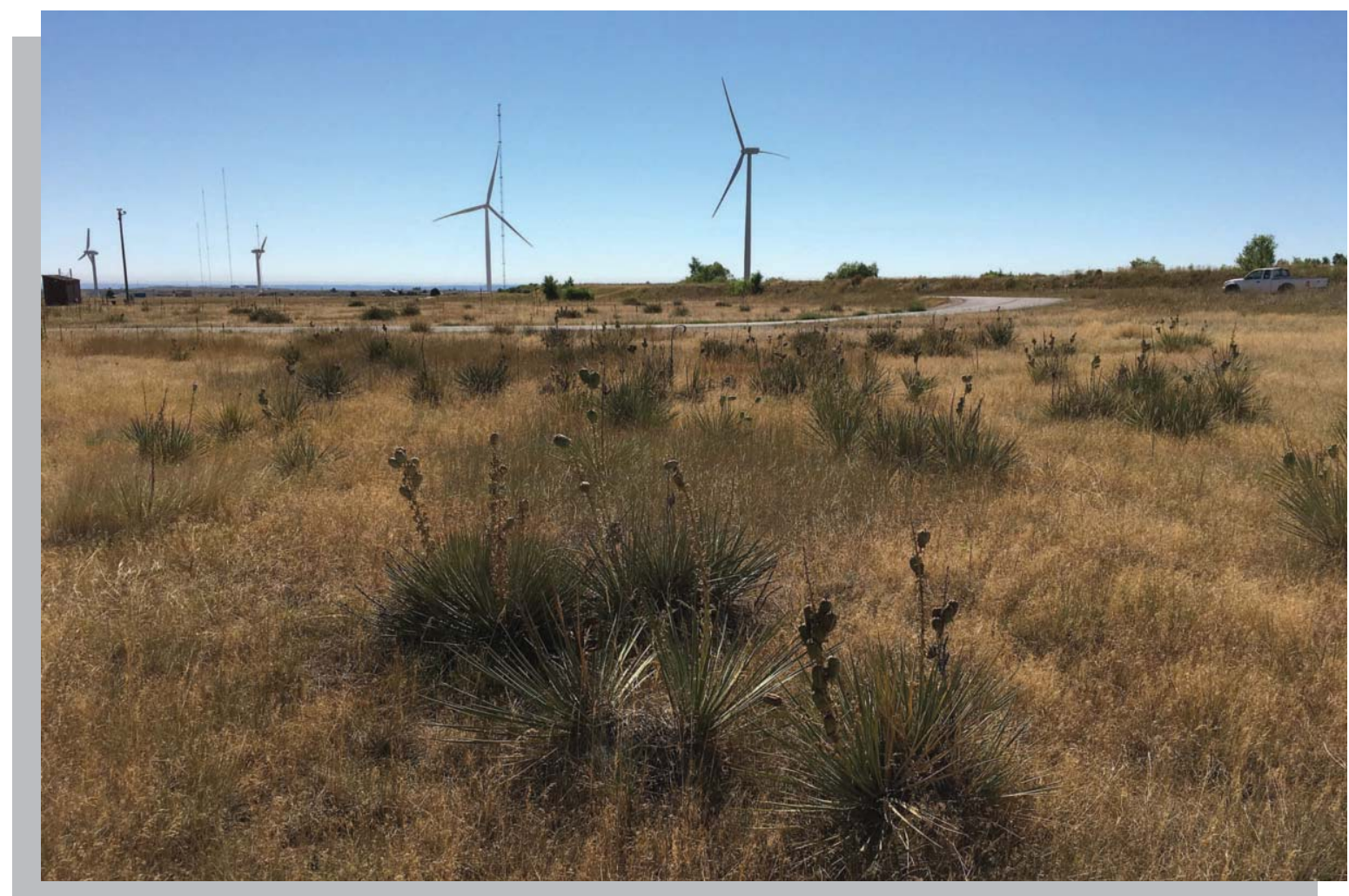

Photo 11 - Mixed yucca and nonnative grasslands at NWTC.

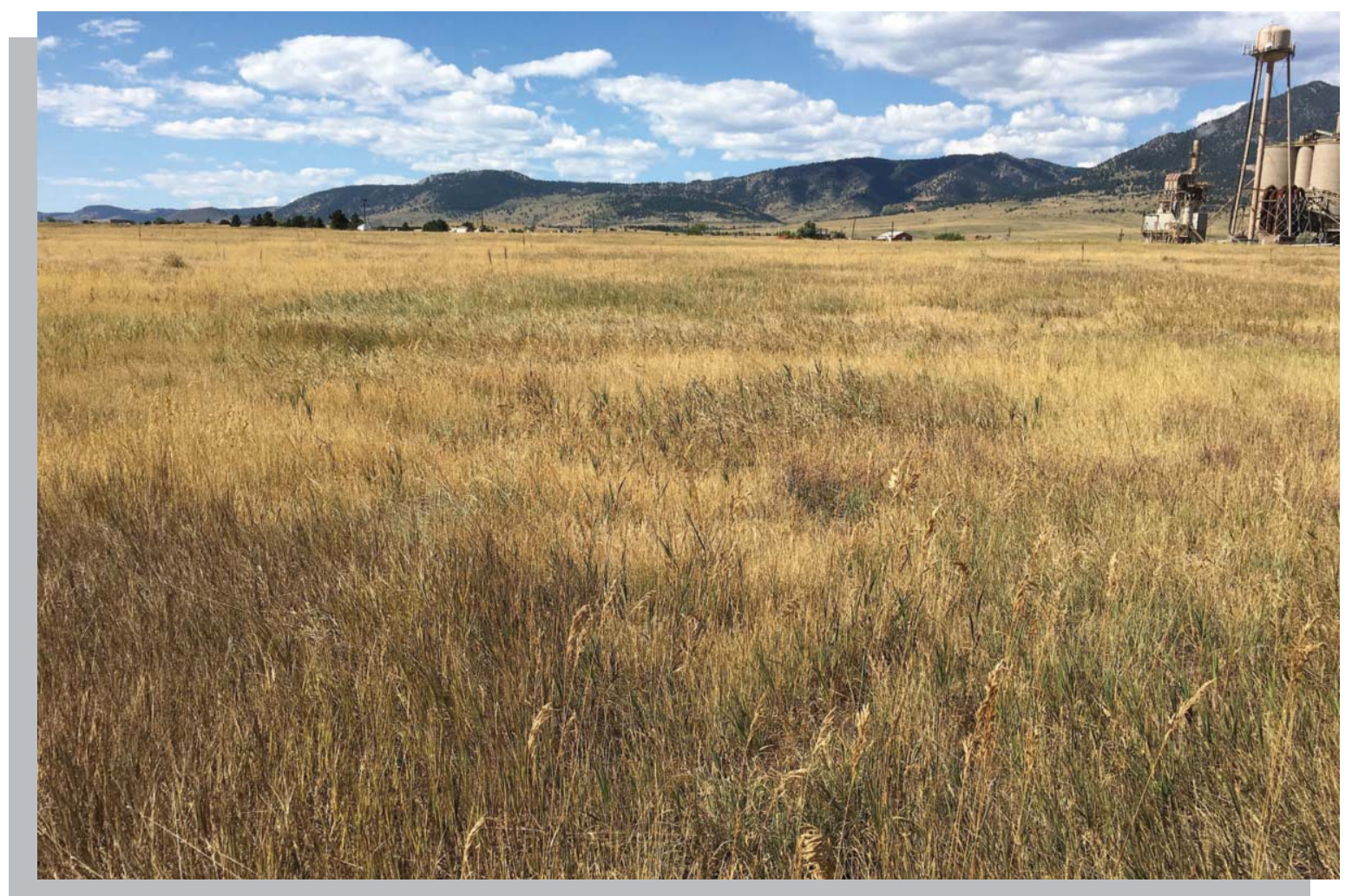

Photo 12 - Degraded grasslands at NWTC. 
РнOTO LOG

National Wind Technology Center

2016 Baseline SuRVeys

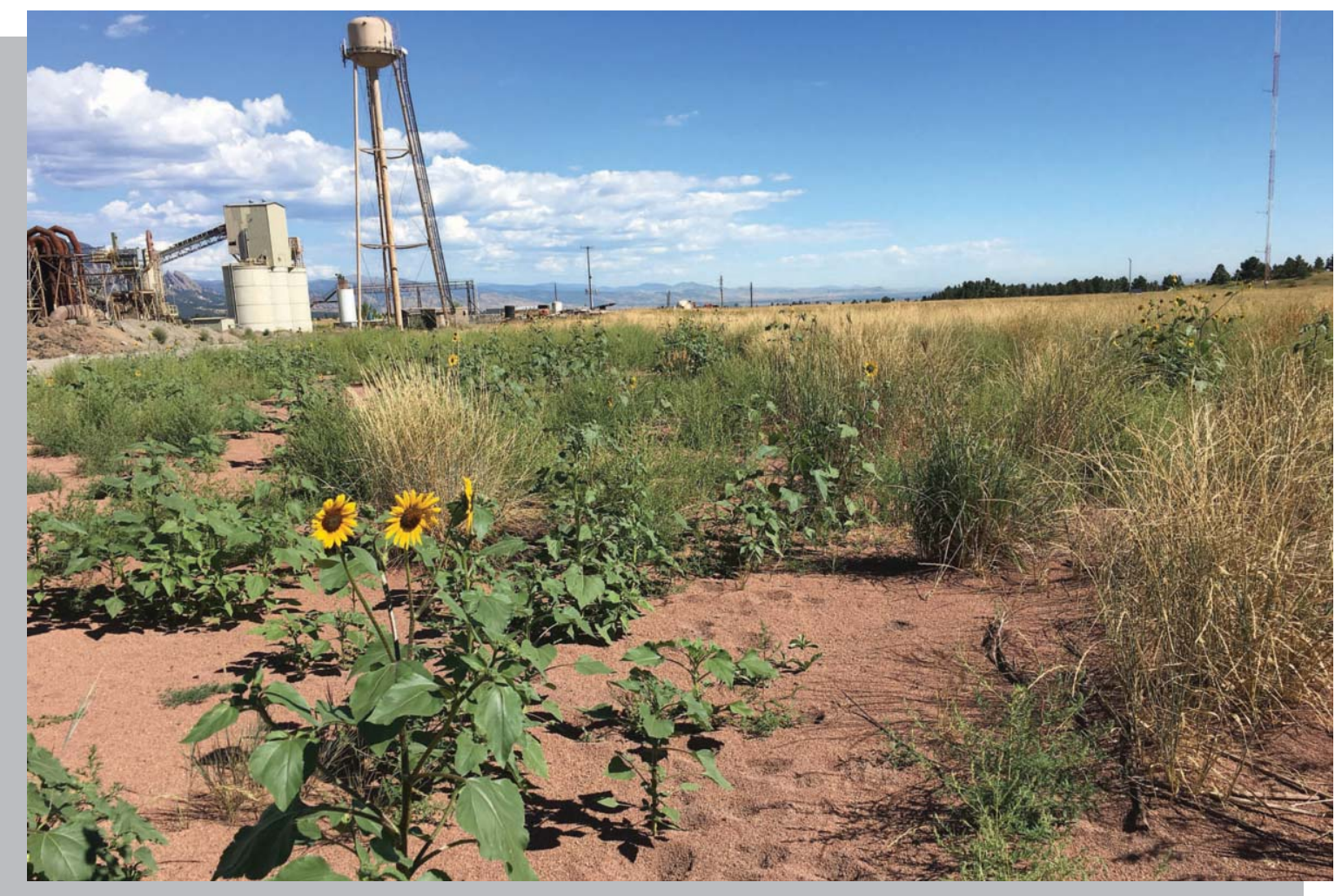

Photo 13 - Highly disturbed area near the southwest corner of NWTC.

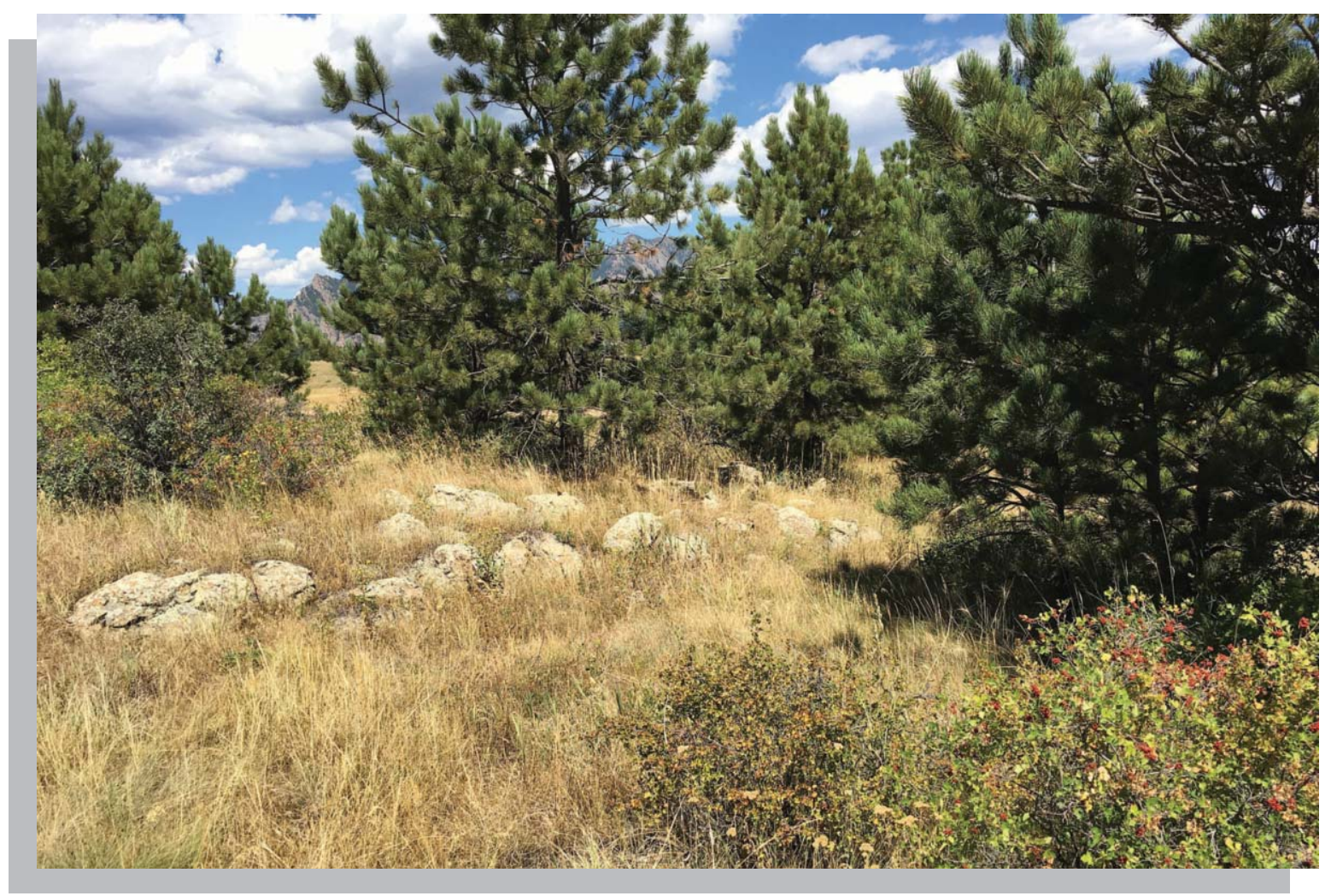

Photo 14 - Ponderosa pine woodlands at NWTC. 
PhOto Log

National Wind Technology Center

2016 Baseline SurVeys

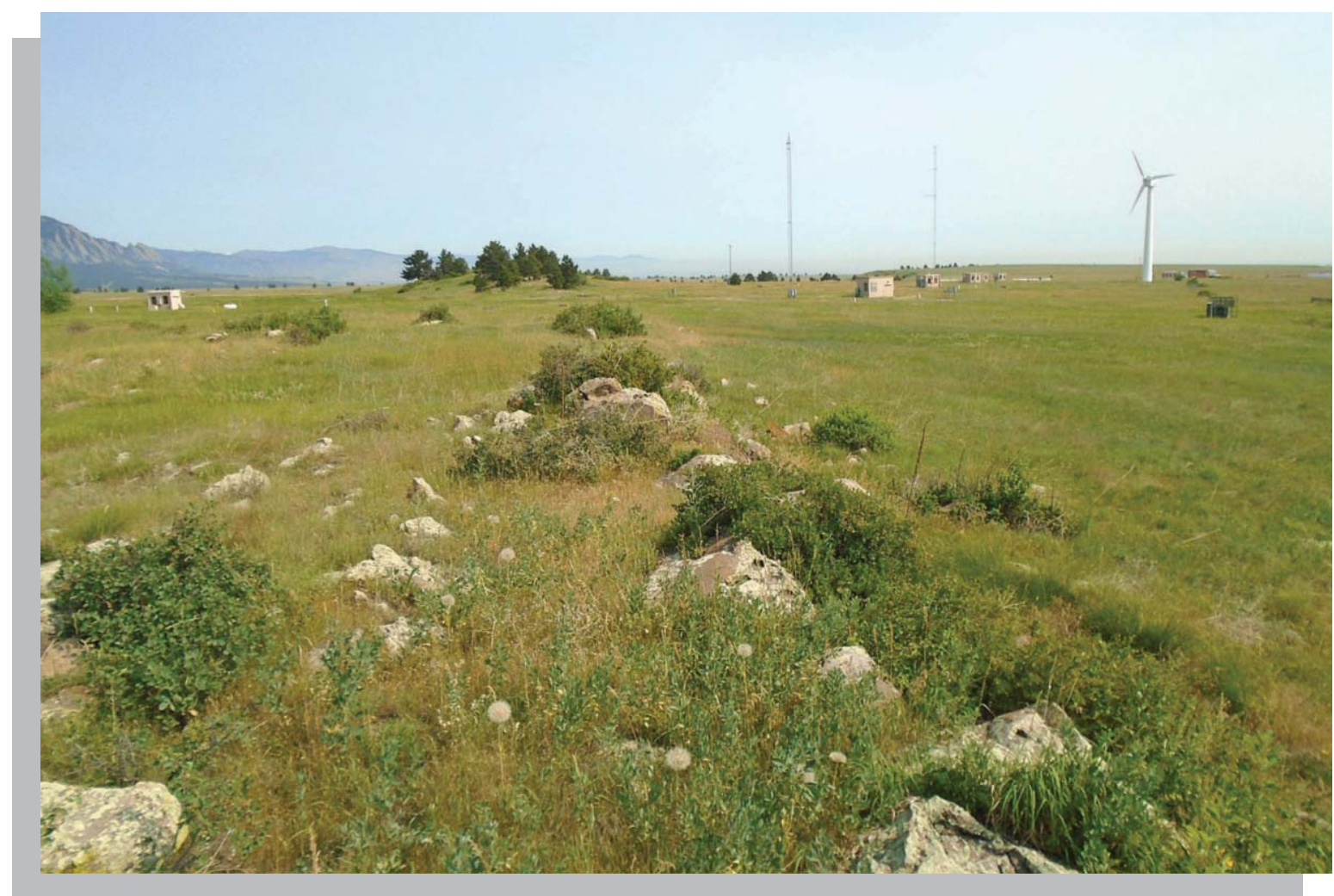

Photo 15 - Mixed shrubland at NWTC.

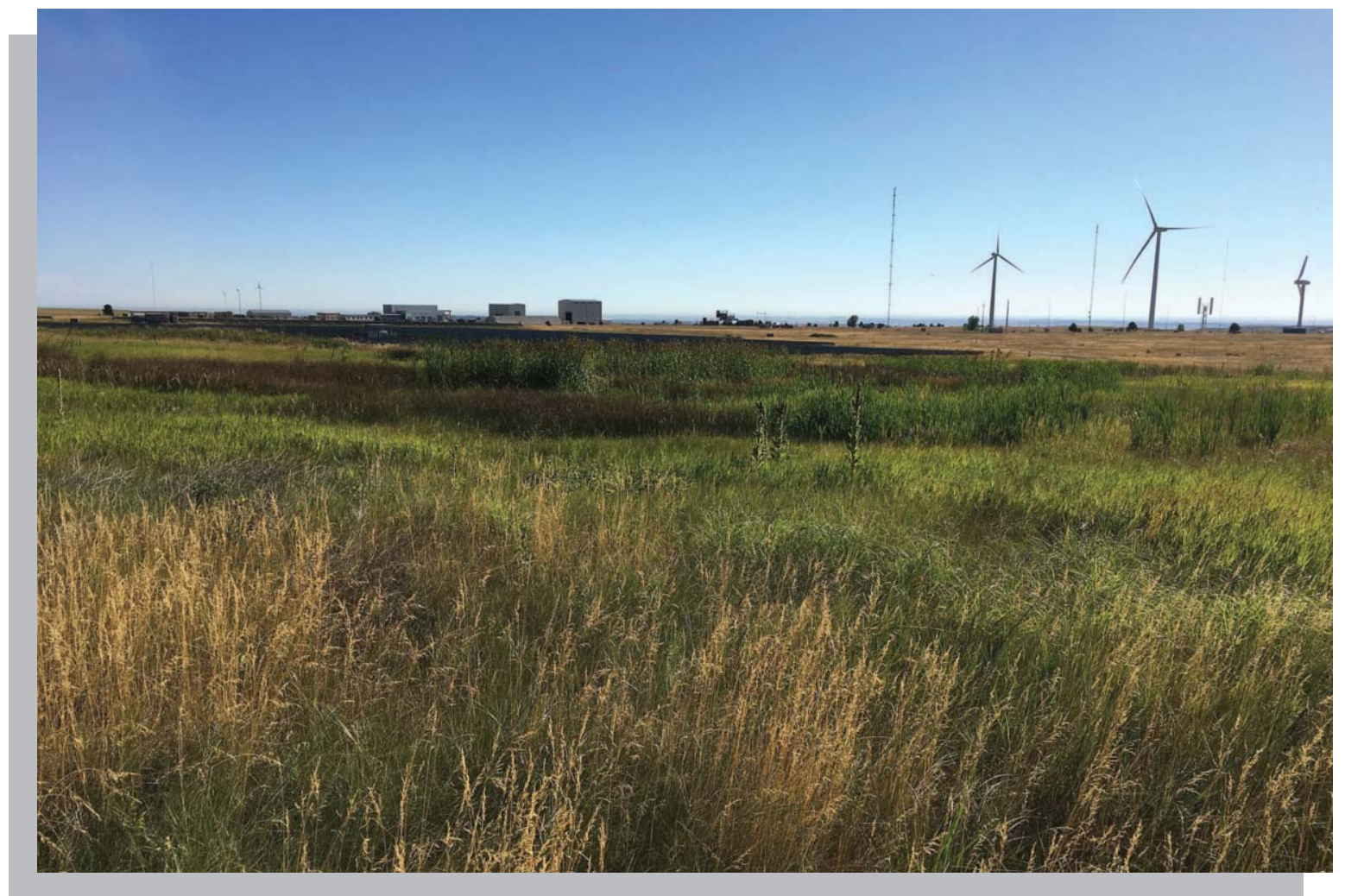

Photo 16 - Palustrine emergent wetlands near the large solar array at NWTC. 
Рното Log

National Wind Technology Center

2016 Baseline SuRVeys

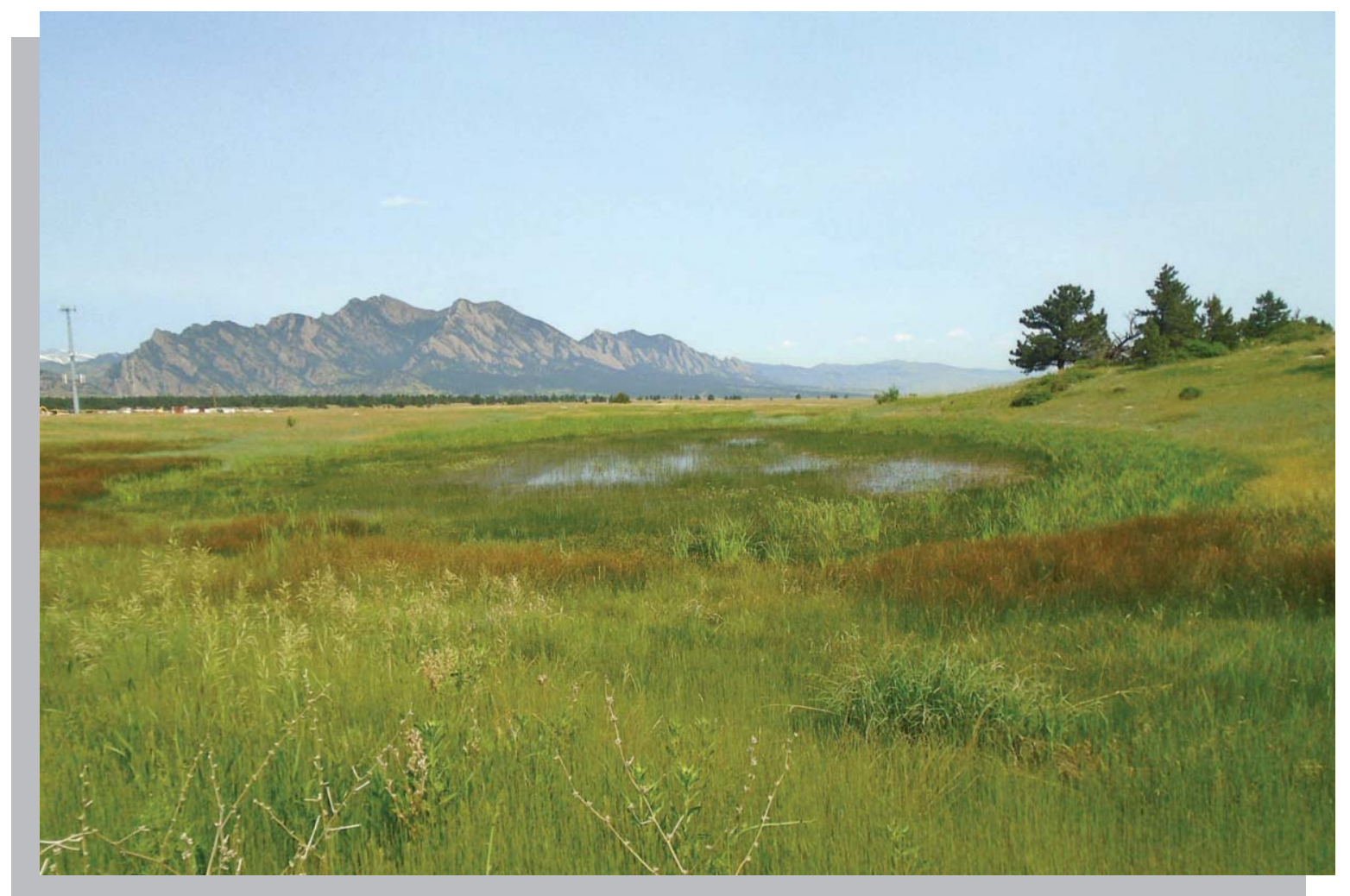

Photo 17 - Palustrine emergent wetlands within the seasonal pond at NWTC.

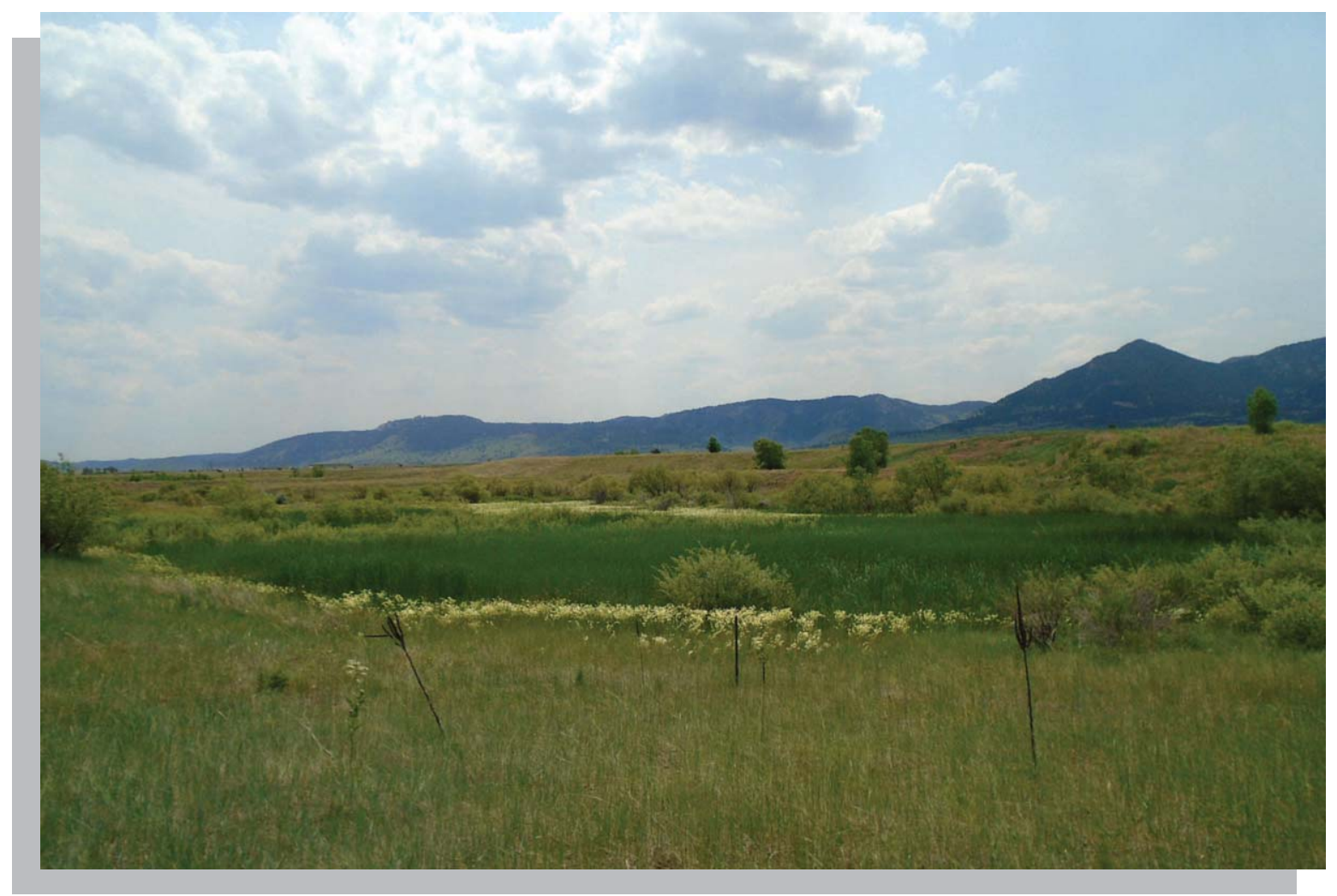

Photo 18 - Palustrine emergent wetlands south of Row 3 at NWTC. 
Рното Log

National Wind Technology Center

2016 Baseline SuRVeys

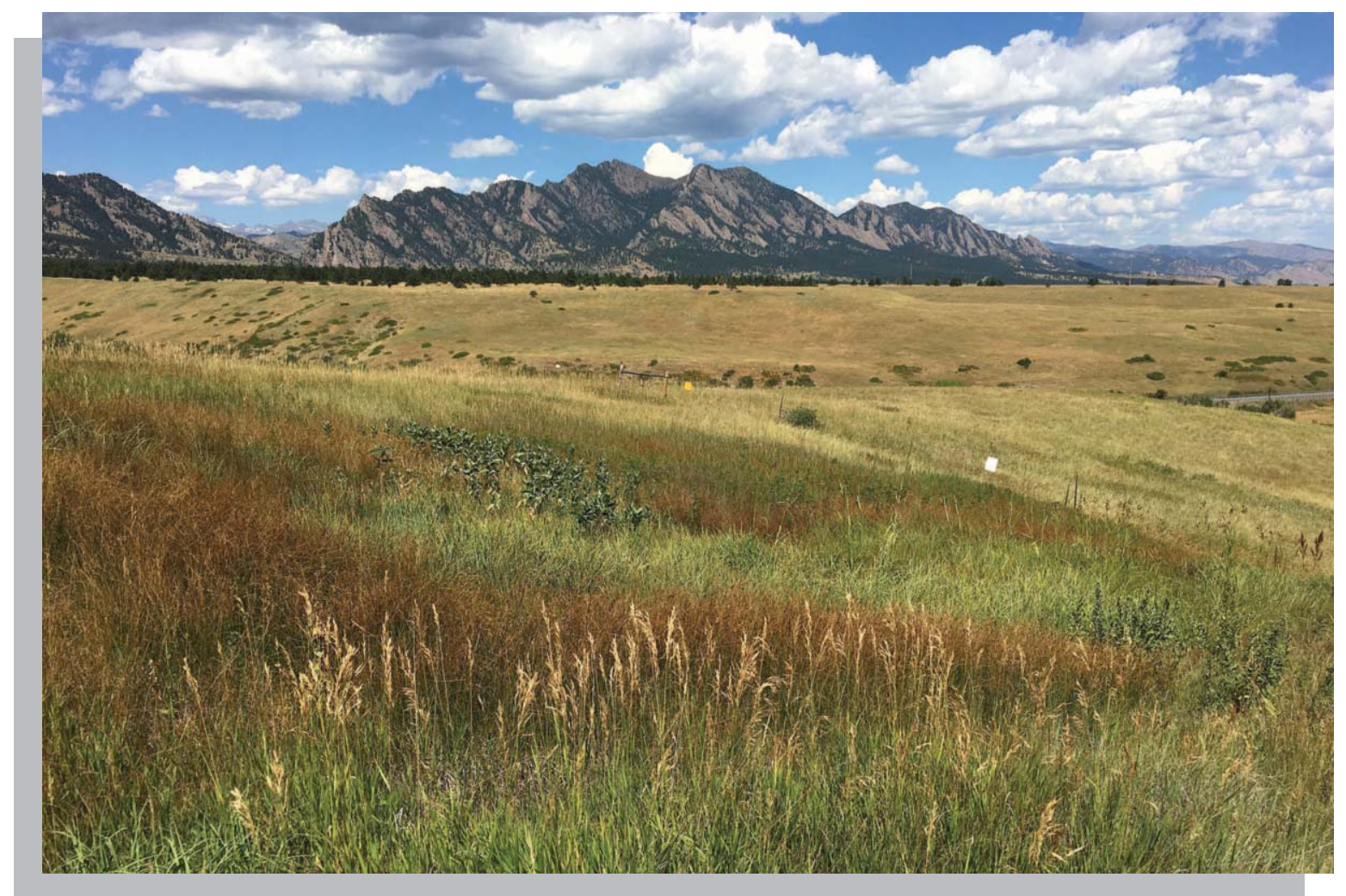

Photo 19 - Palustrine emergent wetlands in the northwest corner of NWTC.

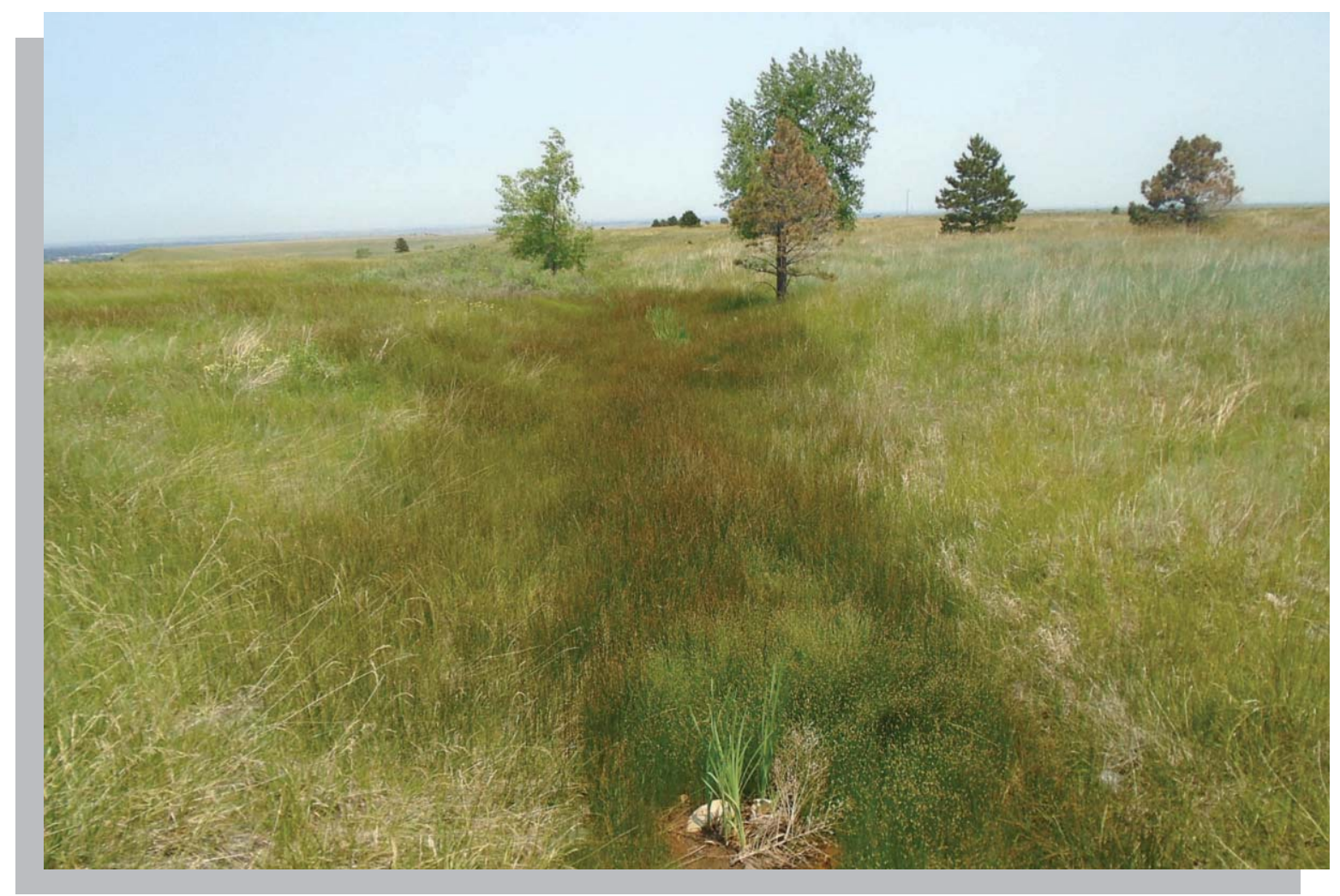

Photo 20 - Riparian emergent wetlands in the northernmost drainage at NWTC. 
PhOto Log

National Wind Technology Center

2016 Baseline SuRVeys

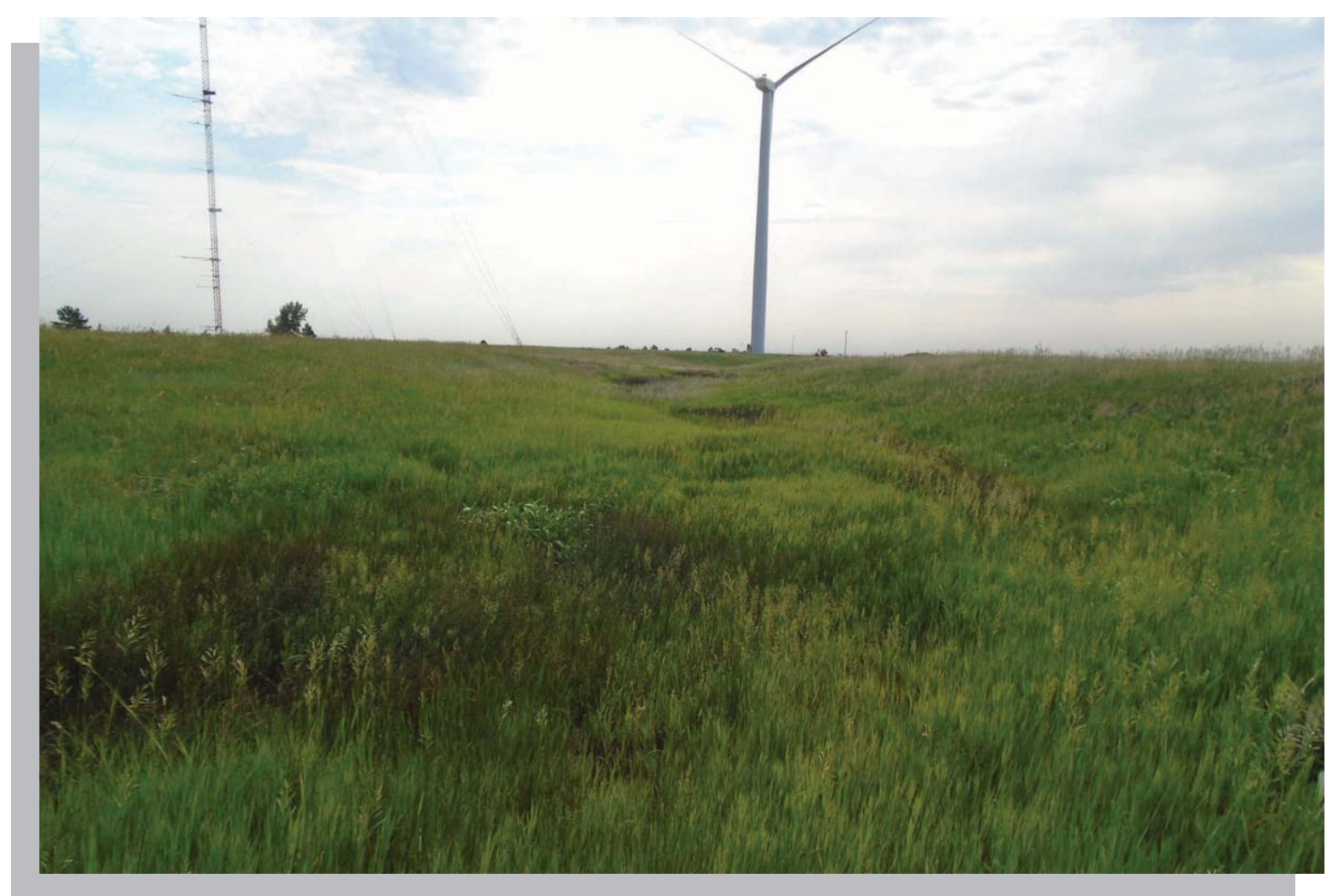

Photo 21 - Riparian emergent wetlands in the southernmost drainage at NWTC.

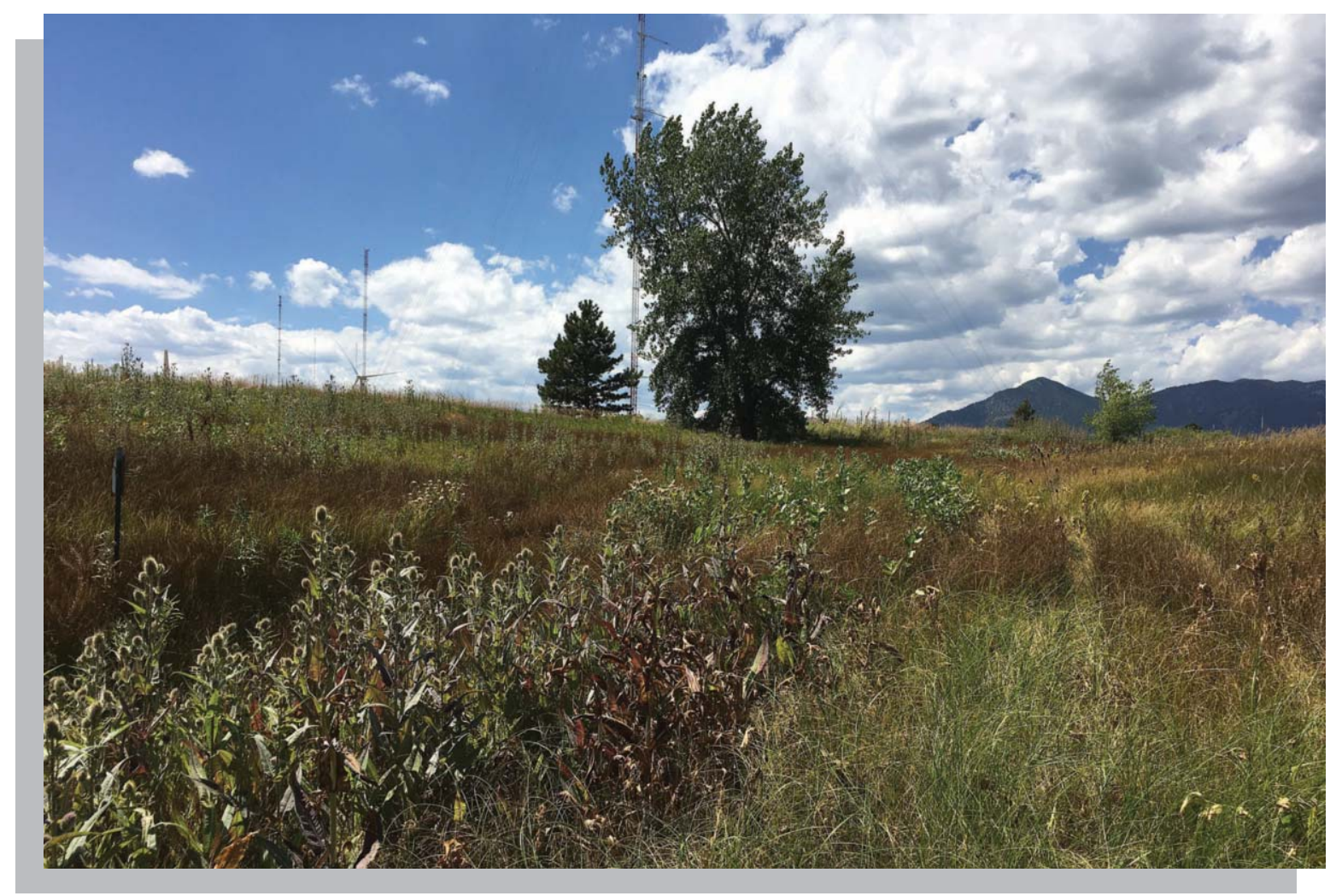

Photo 22 - Dense stands of common teasel and Canada thistle in the northernmost drainage at NWTC. 